\title{
Balancing Trade-Offs Between Deep Energy Retrofits and Heritage Conservation
}

\author{
By \\ Larissa Ide \\ A thesis submitted to the Faculty of Graduate and Postdoctoral Affairs in partial \\ fulfillment of the requirements for the degree of \\ Master of Applied Sciences \\ in \\ Carleton University \\ Ottawa, Ontario \\ (C) 2020 \\ Larissa Ide
}




\section{Abstract}

An $81 \%$ reduction in carbon emissions from existing and heritage buildings by 2030 is required to achieve climate change mitigation targets of preventing warming above $1.5^{\circ} \mathrm{C}$. A methodology and decision framework is presented for deep energy retrofit analyses that balances trade-offs between conservation and sustainability of a building's components. An historic house in Ottawa, Canada was studied to demonstrate the use of the methodology. The energy retrofit analysis suggests $71 \%$ energy savings are achievable through modest envelope retrofits, upgrading HVAC, sensors, controls, and renewable energy. The simple cost payback period is analysed to estimate feasibility for homeowners to implement deep energy retrofits. The carbon emissions saved over 20 years of operation are estimated. This thesis reveals that heritage conservation and sustainability have intersecting values, demonstrating that conserving and upgrading heritage buildings in a respectful way can play a key role in achieving carbon reductions within the existing building stock. 


\section{Acknowledgements}

I am grateful to have had so many amazing opportunities as a student in the NSERC CREATE Heritage Engineering program. I would like to thank everyone who played a role in guiding me and helping me to complete my thesis research and make this a meaningful experience. This includes my supervisors, Dr. Mario Santana and Dr. Scott Bucking, as well as other professors, Dr. Ian Beausoleil-Morrison, Dr. Liam O’Brien, Dr. Burak Gunay, Dr. Mariana Esponda, and Professor Susan Ross. I would also like to thank many colleagues in the Building Performance Research Centre at Carleton University for collaborating and enriching my experience as a master student. I would like to specifically acknowledge and thank $\mathrm{PhD}$ students/candidates Michael Gutland, Tareq Abuimara, Luminita Dumitrascu, and Vasken Dermardiros for their help during my studies. Special thanks go to one of my best friends Adrian Soble for working through the same master's program together and travelling together for academic conferences. I would also like to thank my fiancé, James Heaton, for always supporting me in my endeavours and encouraging me along the journey. My family and James' family have also been great supporters of my master's studies. 


\section{Table of Contents}

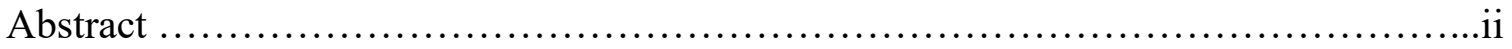

Acknowledgements ..............................................................ii

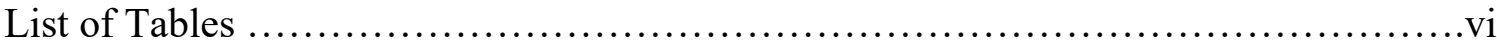

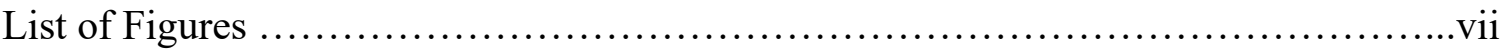

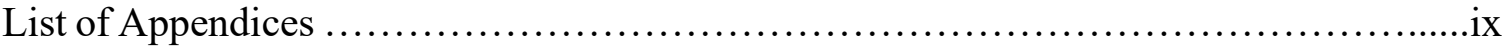

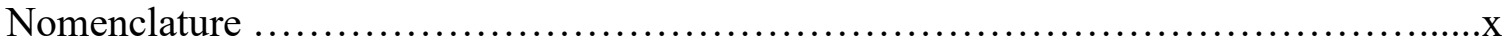

1 Introduction ................................................................................................. 1

1.1 Heritage Conservation and its Role in Climate Change Mitigation...................... 1

1.2 Deep Energy Retrofits and Building Performance Simulation ............................ 4

1.3 Organization of Research and Thesis Document ………………………......... 5

2 Literature Review ……………….................................................................... 5

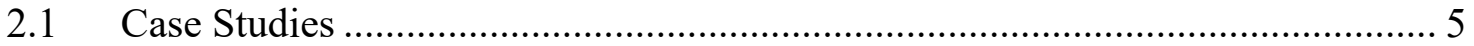

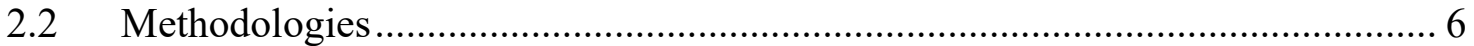

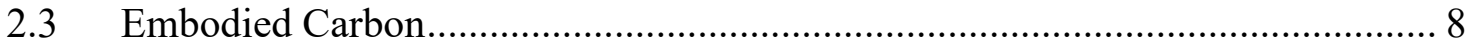

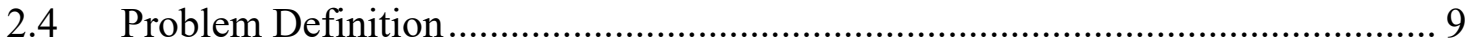

2.4.1 Motivation....................................................................................... 9

2.4.2 Research Objectives and Contributions of Research ................................... 10

3 Case Study - Historical Analysis and Documentation .............................................. 12

3.1 Understanding Heritage Values of the House ..................................................... 13

3.1.1 Current State and Future Intentions ....................................................... 15

3.1.2 Proposed Heritage Statement and Character Defining Elements ............... 17

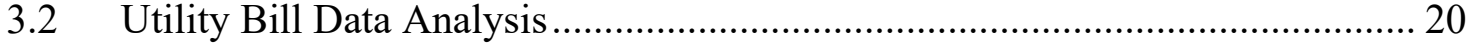

3.2.1 Heating Degree Day Analysis............................................................... 20

3.2.2 Current PV Power Generation ............................................................... 23

4 Detailed Energy Model........................................................................................ 24

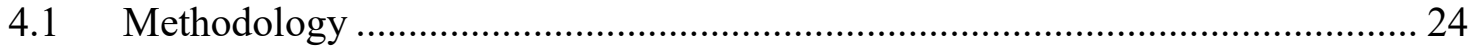

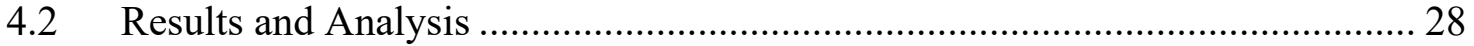

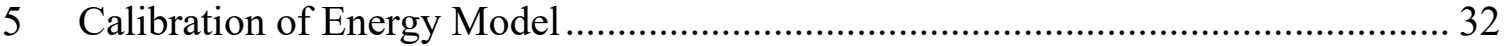

5.1 Sensitivity Analysis.............................................................................. 32

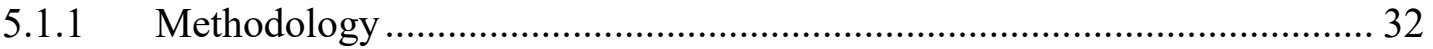

5.1.2 Results and Discussion .......................................................................... 33 


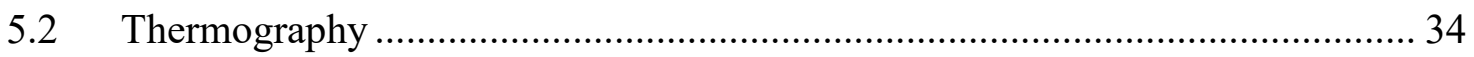

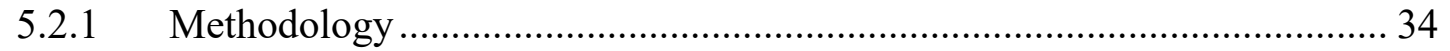

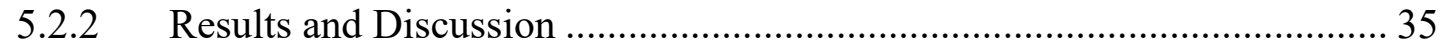

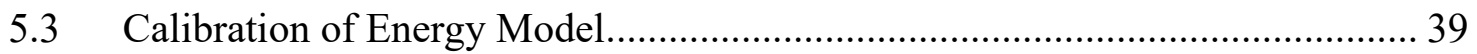

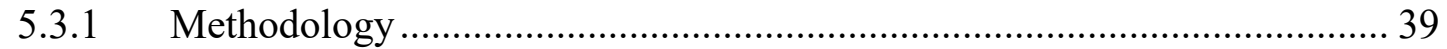

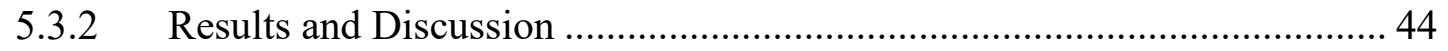

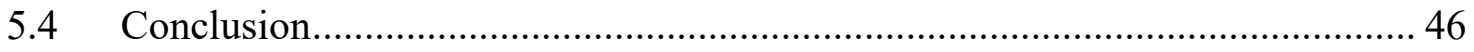

6 Balancing Between Heritage Conservation and Energy Reductions.......................... 47

6.1 Decision framework for Balancing Heritage Conservation and Sustainability . 47

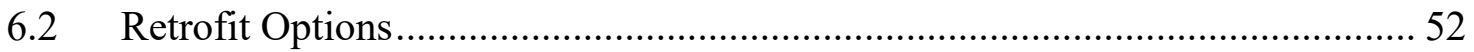

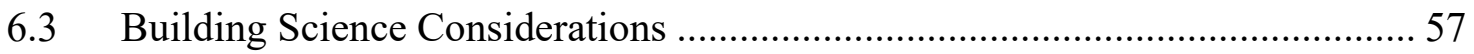

6.4 Ranking of Options and Recommended Package ............................................... 58

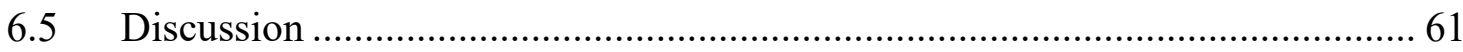

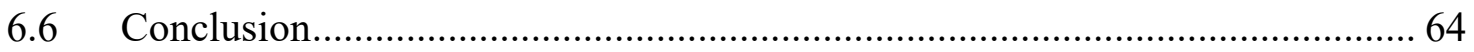

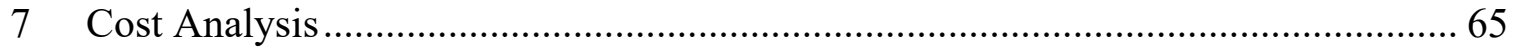

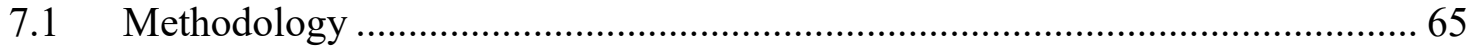

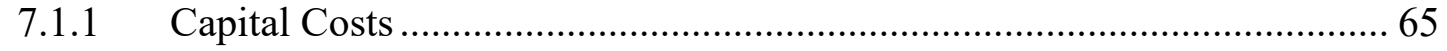

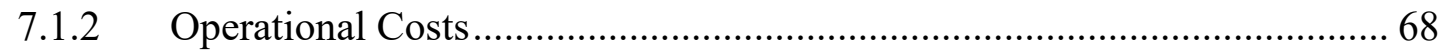

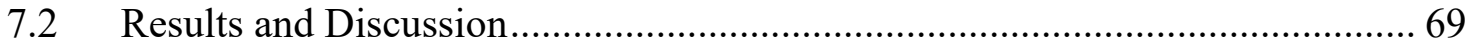

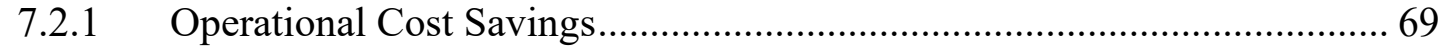

7.2.2 Payback Period................................................................................... 71

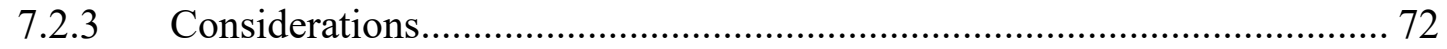

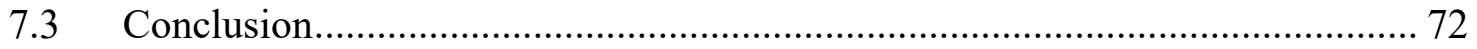

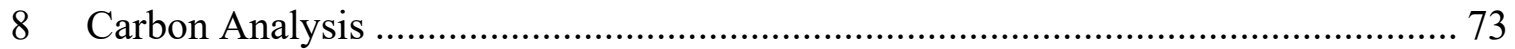

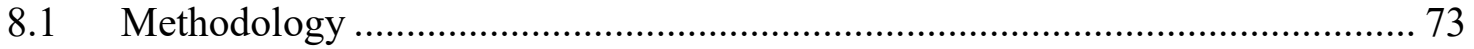

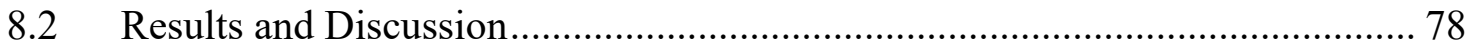

8.2.1 Carbon Emissions Calculations using Athena ………………………….... 78

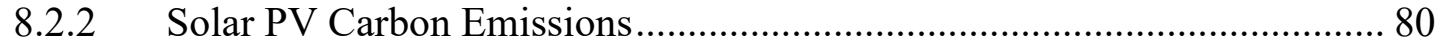

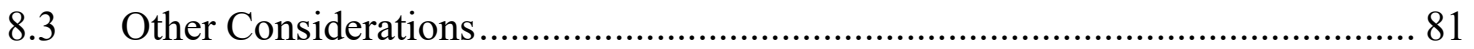

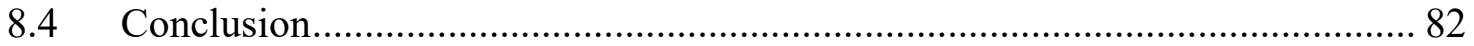

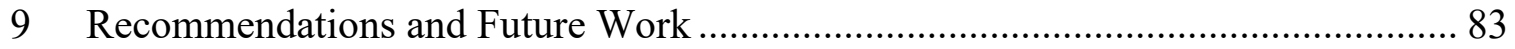

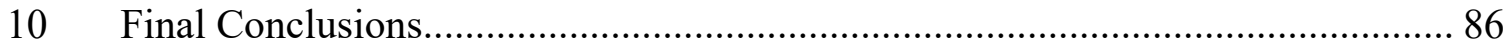

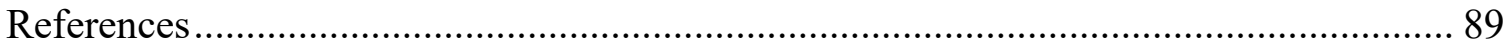




\section{List of Tables}

Table 1: Findings from case studies about energy retrofits in historic buildings in cold climates 6

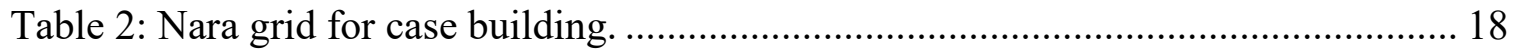

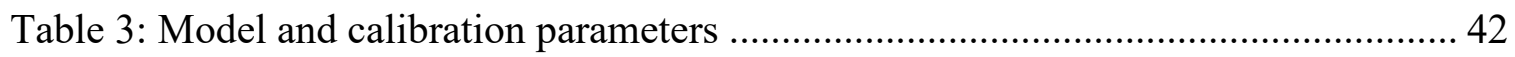

Table 4: Summary of retrofits explored, values simulated for analysis, and heritage impact

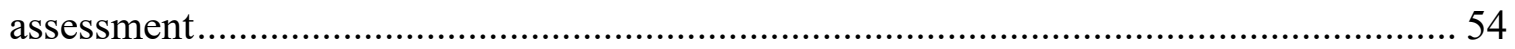

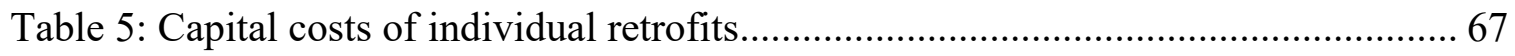

Table 6: Total on/off/mid peak hours and electricity time of use costs for baseline and

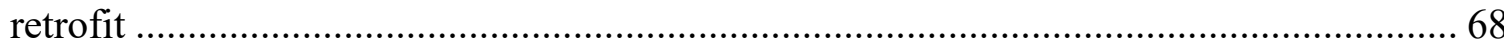

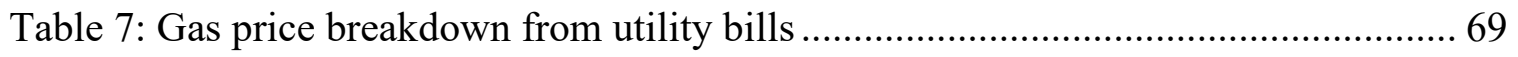

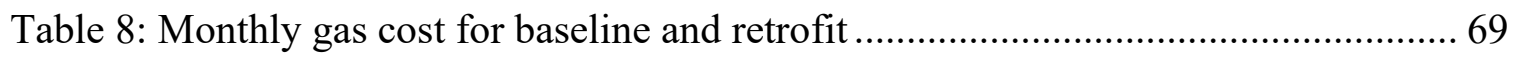

Table 9: Summary of baseline and retrofit operational costs ...................................... 70

Table 10: Summary of simple payback for complete retrofit package considering different

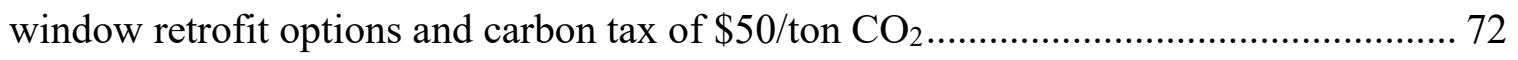

Table 11: Assumptions made for the existing building material inputs for Athena calculations 75

\section{List of Figures}

Figure 1: Proposed methodology for deep energy retrofit analysis in historic buildings.. 11

Figure 2: 166 Glebe Avenue, Ottawa. Angela's Bed and Breakfast .............................. 13

Figure 3: 174 and 176 Glebe Avenue, June 1974 (Elliott, 2011) .................................. 14

Figure 4: Rear view of case study house. Deteriorated wood shingles on roof of back

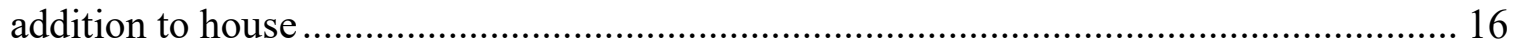

Figure 5: Basement door to exterior. Deterioration due to moisture ............................... 16

Figure 6: Measured gas and electricity consumption for 2015-2017 ............................ 22

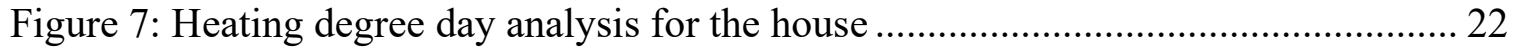

Figure 8: Current PV power generation intensity in $\mathrm{kWh} / \mathrm{m}^{2}$ for $2015-2017$. The average

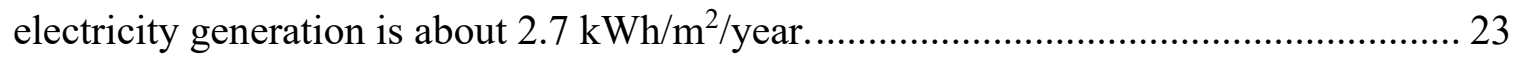

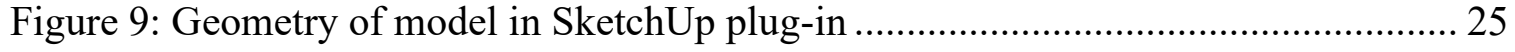

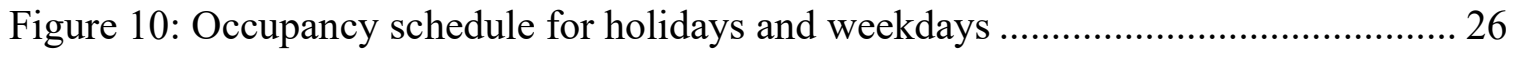
vi 
Figure 11: Zone operative air temperature with $75 \mathrm{~W} / \mathrm{m}^{2}$ capacity baseboard heaters for each zone

Figure 12: Zone operative air temperature with $105 \mathrm{~W} / \mathrm{m}^{2}$ capacity baseboard heaters for

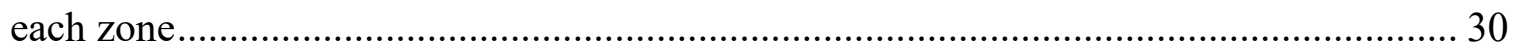

Figure 13: Zone air infiltration $(\mathrm{ACH})$ for calibrated baseline model .......................... 31

Figure 14: Summary of sensitivity analysis results for change in annual gas energy ...... 33

Figure 15: Thermography showing patterns suggesting air infiltration.......................... 35

Figure 16: Patterns suggesting air infiltration along base of addition back door ............ 36

Figure 17: Heat transfer around roof (third floor) and chimney .................................. 36

Figure 18: Hole in basement wall discovered with thermography ............................... 36

Figure 19: Potential thermal bridging or moisture issue in wall ................................. 37

Figure 20: Potential moisture issue or thermal bridging in basement addition wall ........ 37

Figure 21: Historic double pane window performing quite well .................................. 38

Figure 22: Table displaying NMBE and CV(RMSE) values for different ACH values of air

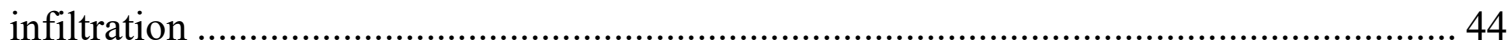

Figure 23: Measured gas and calibration results for gas energy use ........................... 45

Figure 24: Measured electricity and calibration results for electricity energy use .......... 46

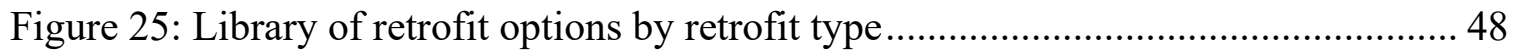

Figure 26: Decision framework for balancing energy reductions and heritage conservation,

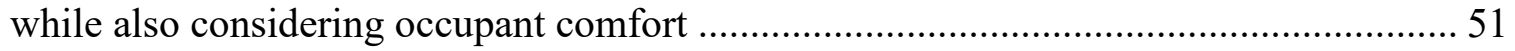

Figure 27: Wall details of existing wall in main part of house and three rehabilitation

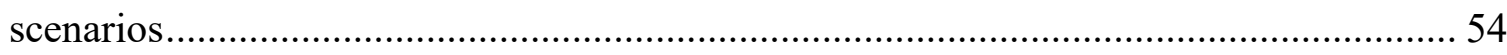

Figure 28: Results of parametric analysis of retrofit options......................................5 59

Figure 29: Incremental annual energy savings of package of retrofits .......................... 61

Figure 30: End use breakdown for recommended retrofits combined.......................... 63

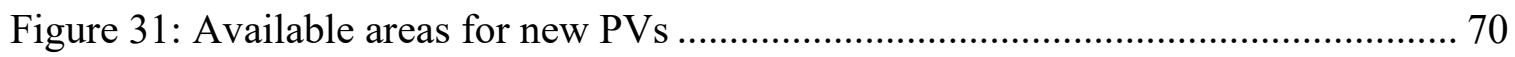

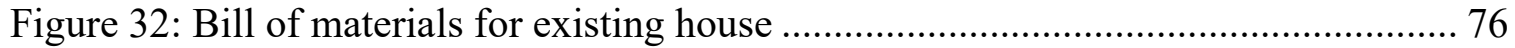

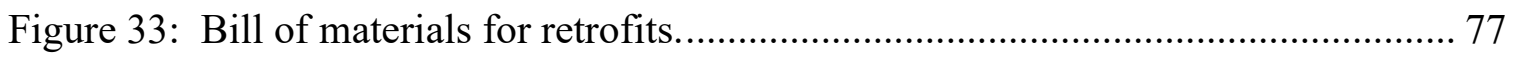

Figure 34: Avoided carbon emissions of conserving existing building components ....... 79

Figure 35: Existing unretrofitted vs retrofitted carbon emissions ................................ 79 
Figure 36: Existing unretrofitted vs retrofitted (including solar PV) embodied and

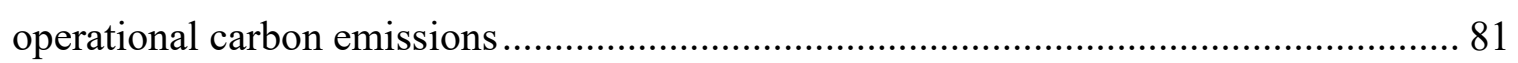

Figure 37: Existing building embodied energy, 180 years, A to C................................ 109

Figure 38: Embodied energy of envelope retrofits, 20 years, A to C ............................. 110 


\section{List of Appendices}

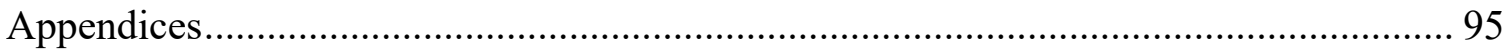

A: Floor Plans used to create initial model geometry ………........................................ 95

B: Model Geometry and Model Details ...................................................................... 96

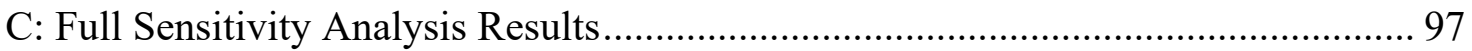

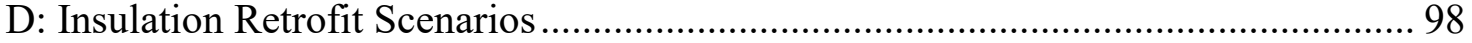

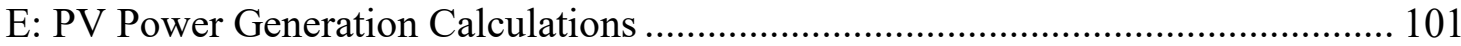

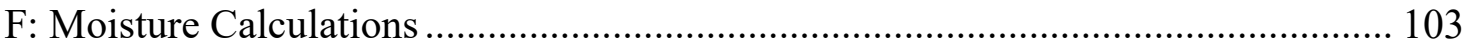

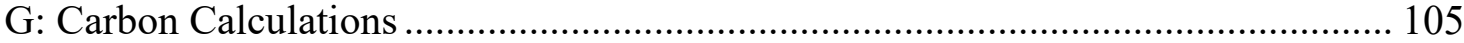

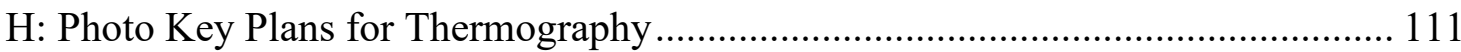

I: Potential Heritage Impact Assessment .................................................................. 114 


\section{Nomenclature}

\begin{tabular}{ll} 
ACH & Air-changes per hour \\
AMY & Actual meteorological year \\
ASHP & Air-source heat pump \\
ASHRAE & American Society of Heating, Refrigeration and Air-Conditioning \\
& Engineers \\
CAD\$ & Canadian dollar \\
CV(RMSE) & Coefficient of variation of the root mean square error \\
DER & Deep energy retrofit \\
DHW & Domestic hot water \\
Eppy & Library in Python for editing EnergyPlus files \\
EUI & Energy use intensity \\
g CO 2 eq & Grams of carbon dioxide equivalent \\
GHG & Greenhouse gas emissions \\
GoF & Goodness of fit \\
GWP & Global warming potential \\
HB & Historic/heritage building \\
HDD & Heating degree day \\
HRV & Heat recovery ventilator \\
HVAC & Heating ventilation and air-conditioning \\
ICOMOS & International Council on Monuments and Sites \\
IDF & Input description file for EnergyPlus \\
IEQ & Indoor environmental quality \\
LBNL & Lawrence Berkeley National Laboratory \\
Low-E & Low emissivity coating for window glazing \\
NECB & National Energy Code of Canada for Buildings \\
NMBE & Normalized mean bias error \\
PIR & Polyisocyanurate \\
PV & Photovoltaics \\
R & Coefficient of determination \\
RH & Relative humidity \\
\hline
\end{tabular}


R-value Thermal resistance of an object

SHGC Solar heat gain coefficient

TMY

Typical meteorological year

U-value Thermal conductance of an object 


\section{Introduction}

\subsection{Heritage Conservation and its Role in Climate Change Mitigation}

The development of new buildings to replace existing buildings is around $1.0-3.0 \%$ per year in developed countries (Ma, Cooper, Daly, \& Ledo, 2012) because of the long lifespan of buildings. Existing and heritage buildings that are present today are estimated to comprise about $75 \%$ of the building stock in 2030 (Schulte, 2018). For these reasons, it is recommended by the IPCC Special Report on $1.5^{\circ} \mathrm{C}$ (Zhou, 2018) to put efforts into retrofitting the existing building stock of developed areas, "to avoid lock-in of inefficient carbon and energy-intensive buildings." The IPCC Special Report on $1.5^{\circ} \mathrm{C}$ reveals that carbon emissions from the building sector need to reduce from about $8 \mathrm{Gt}^{\mathrm{CO}_{2}} /$ year in 2010 to around 1.5 to $2.2 \mathrm{GtCO}_{2} /$ year in 2030 ( $81 \%$ reduction) and 0.1 to $0.9 \mathrm{GtCO}_{2} /$ year in 2050 (99\% reduction).

Although it is evident that carbon reductions are required, the rate of energy retrofits to achieve this within existing buildings globally is at a low rate of $2.2 \%$ per year (Ma et al., 2012). The NECB (National Energy Code of Canada) outlines energy performance standards for new construction (CCBFC, NRC, 2015), while the Ontario provincial building energy code has identified that conservation of existing buildings and energy upgrades should be a focus for achieving energy and carbon reduction targets, recognizing that the upgrades should not be detrimental to the conservation of cultural values within heritage buildings (MMAH, 2016). The question then is, how can deep energy retrofits be undertaken in heritage buildings in a respectful way and what are the potential carbon savings? Though there may be some conflicts between heritage conservation and sustainability, there is a missed opportunity in retrofitting heritage 
buildings to improve their overall sustainability, while conserving important cultural values.

While the current operational carbon emissions of existing buildings may be greater than new low-carbon buildings, there are other sustainability reasons to retrofit existing buildings. Reusing buildings contributes to the UN Sustainable Development Goals 11.6 by reducing environmental impact through reduction of construction materials and waste, and 11.C by making buildings more resilient through retrofits to reduce energy use and improve comfort (United Nations, 2019). Grytli, Kvaerness, Rokseth, \& Ygre, (2014) compared the environmental impact of operational energy use and life cycle carbon for different conservation scenarios for an historic building. The study found that conserving the historic building and improving its energy efficiency has a lower environmental impact than replacement with a new building built to passive house standards. These findings were dependent on the lifespan of the historic building and demonstrate that there is a greater importance to reduce the energy use of the building as the lifespan increases (Grytli et al., 2014).

The existing building stock in the U.S. consists of over $90 \%$ built before the 1990 s which are now requiring major retrofits (Diamond, 2001). These retrofits may be for seismic performance and to prevent safety risks due to natural deterioration, to improve thermal comfort and energy performance (Webb, 2017), to conserve heritage values through preservation and rehabilitation (Grimmer, 1995), and for adaptive reuse by current 
and future generations (Bullen \& Love, 2011). Historic buildings (HBs) ${ }^{1}$ worldwide present a great opportunity to achieve large energy reductions as they comprise between $10 \%$ and $40 \%$ of the building stock and will continue to exist because of their cultural value (CIBSE, 2002; DOE, 2011; Economidou et al., 2011; Troi, 2011; Webb, 2017). A study was done for the EU, showing that there is potential for large-scale carbon savings of 180 $\mathrm{Mt} \mathrm{CO}_{2}$ emissions through a $75 \%$ reduction in carbon emissions by energy retrofitting $\mathrm{HBs}^{2}$ (Troi, 2011). These carbon savings equate to about $2 \%$ of the carbon emissions from the global building sector in 2010 (Zhou, 2018). The carbon and energy cost savings are in addition to the benefits of increased indoor comfort and decreased energy costs, improving overall sustainability (Troi, 2011). In Canada, 48\% of residential building energy use is from buildings constructed before 1977 (NRCan, 2016). If all these buildings implemented retrofits to achieve a $75 \%$ reduction in carbon emissions, then the carbon savings would be about 39.7 $\mathrm{Mt} \mathrm{CO}_{2}$ (NRCan, 2016; Senate, 2018). Although these carbon savings are only $0.5 \%$ of the global building emissions, every country needs to do their best to help achieve climate mitigation targets.

Currently, HBs are exempt from energy efficiency codes in many regions (EUParliament, 2010; CCBFC, NRC, 2015), but it is likely that energy reduction targets will also be required in HBs soon to meet climate change targets. There are similarities between implementing energy retrofits in existing buildings and in historic and traditional buildings (Webb, 2017). The main differences between energy retrofits in these buildings are

\footnotetext{
${ }^{1}$ An historic (or heritage) building in this thesis defines a building that is 40 years or older, has retained most of its original building fabric, and has cultural significance for a community.

${ }^{2}$ This study considered all buildings in the EU constructed before 1945 as historic. 
encountered within the physical characteristics of the building (e.g. the construction materials are non-homogenous, HVAC systems are older and inefficient, etc.) and the constraint of conserving the cultural values within these HBs (Webb, 2017).

\subsection{Deep Energy Retrofits and Building Performance Simulation}

Deep energy retrofits are defined as "a major building renovation project in which site energy use intensity (including plug loads) has been reduced by at least $50 \%$ from the prerenovation baseline with a corresponding improvement in indoor environmental quality and comfort" (IEA, 2017). This type of retrofit requires a detailed whole building analysis where the performance of building systems is considered together (IEA, 2017). If the typical retrofits of achieving between $10-20 \%$ energy savings from no-cost to low-cost options are followed for existing buildings, then the carbon reduction targets to mitigate climate change effects of warming above $1.5^{\circ} \mathrm{C}$ will not be achieved (Fifita et. al, 2018).

The difficulty in achieving deep energy retrofits in HBs is that a prescriptive compliance pathway is not a viable option to conserve the heritage values of the building. This pathway may not be viable since it prescribes low levels of air infiltration or specific R-values for envelope components, among other things, which may not be attainable for the type of construction of HBs (Pracchi, 2014). A performance compliance pathway allows deviations from prescribed energy requirements through energy analyses that demonstrate the desired building performs better than a prescribed building of the same

massing and internal loads. This makes a performance compliance pathway a better option to conserve heritage buildings. However, creating a calibrated energy model is more 
difficult for HBs because of their unique constructions (Adhikari et al., 2011) and lack of as-built documentation.

\subsection{Organization of Research and Thesis Document}

This document includes the literature review, background information on the case study, methodology, sensitivity analysis, thermography, calibration of energy model, use of decision framework, cost analysis, and carbon analysis. Finally, concluding remarks summarize the findings and provide suggestions for further research.

\section{Literature Review}

\subsection{Case Studies}

There are a few studies that demonstrate deep energy retrofits can save between $40-89 \%$ energy in historic buildings in cold climates (Bin \& Parker, 2012; Jermyn \& Richman, 2016), exploring combinations of envelope retrofits and HVAC upgrades to achieve great energy savings. See Table 1 for a summary of these deep energy retrofit case studies. Alev et al. (2014), Harrestrup and Svendsen (2015), Morelli et al. (2012) suggest insulating the walls to achieve high energy savings of $14 \%$ to $47 \%$. This recommendation may be appropriate depending on the wall assembly and environmental conditions. Straube and Schumacher, (2007) advise specific methods to prevent deterioration risk as the wall assembly will experience a large change in temperature and moisture conditions. Adding insulation to an existing building can be invasive and costly, but the benefits of improved occupant health and reduced energy costs outweigh the cost of adding insulation by 1.9:1 (Chapman et al., 2009). Infiltration can contribute up to $50 \%$ of total heat loss in a building making air-tightening an important retrofit option (Sedovic \& Gotthelf, 2005). Rehabilitating a building envelope to have an air-barrier and air-sealing leakage areas 
should be able to achieve $4.4 \mathrm{ACH}$ at $50 \mathrm{~Pa}$ as this is the average for residential buildings in Canada (Fennell \& Haehnel, 2005). Additional case studies in North American cold climates are important, as less than $5 \%$ of publications originate in continents other than Europe and Asia (Bertolin \& Loli, 2018). Blaszak \& Richman, (2013) noted that energy retrofit strategies will have varying effects for different types, styles, and ages of houses, which varies from region to region.

Table 1: Findings from case studies about energy retrofits in historic buildings in cold climates

\begin{tabular}{lll}
\hline HB state & Retrofit & Energy Savings \\
\hline $\begin{array}{l}\text { High thermal conductivity of } \\
\text { envelope }\end{array}$ & $\begin{array}{l}\text { Additional interior insulation on } \\
\text { exterior walls }\end{array}$ & $\begin{array}{l}14-47 \% \text { (Alev et al., 2014; } \\
\text { Harrestrup \& Svendsen, 2015; } \\
\text { Morelli et al., 2012) }\end{array}$ \\
\hline $\begin{array}{l}\text { High air leakage through cracks, } \\
\text { openings, and envelope } \\
\text { construction }\end{array}$ & Air-tightening & $\begin{array}{l}5-6 \% \text { after improving thermal } \\
\text { performance of envelope (Alev } \\
\text { et al., 2014; Morelli et al., 2012) }\end{array}$ \\
\hline Inefficient HVAC & $\begin{array}{l}\text { Upgrade to new efficient } \\
\text { systems that have low impact on } \\
\text { heritage character }\end{array}$ & $\begin{array}{l}50-68 \% \text { (Arumägi \& Kalamees, } \\
2014 ; \text { Morelli et al., 2012) }\end{array}$ \\
\hline $\begin{array}{l}\text { Heating setpoint and window } \\
\text { opening }\end{array}$ & $\begin{array}{l}\text { Influence occupant behaviour to } \\
\text { reduce window opening and } \\
\text { lower heating setpoint }\end{array}$ & $\begin{array}{l}50 \% \text { relative to a high energy } \\
\text { user scenario (Ben \& Steemers, } \\
2014)\end{array}$ \\
\hline $\begin{array}{l}\text { High thermal conductance and } \\
\text { air leakage of windows }\end{array}$ & $\begin{array}{l}\text { Replace with new lower thermal } \\
\text { conductance windows }\end{array}$ & $\begin{array}{l}5 \% \text { (Arumägi \& Kalamees, } \\
2014 ; \text { Morelli et al., 2012) }\end{array}$ \\
\hline
\end{tabular}

\subsection{Methodologies}

Many papers (Adhikari et al., 2011; Alongi, Scoccia, Motta, \& Mazzarella, 2015; Ascione, de Rossi, \& Vanoli, 2011; Grytli et al., 2014; Loli \& Bertolin, 2018; Ma et al., 2012; Young, 2012) outline methodologies for conservation and sustainability projects with a commonality being that a high level of understanding of the building is required prior to analyses. Ma et al., (2012) outline a methodology for cost optimal retrofits of existing buildings. This methodology describes many important things to consider in the methodology for a HB energy retrofit such as: an initial survey of the building and 
definition of project objectives, energy audit and performance assessment, identification of retrofit options through several analysis methods (energy, economic, risk assessment, etc.), site implementation, and validation and verification of energy savings. Loli \& Bertolin (2018) outline that the following should be included in a methodology balancing heritage conservation and sustainability: identifying the cultural values of a building and protecting them, determining level of intervention based on condition of structure, reducing costs without compromising occupant comfort, compatibility with existing materials, and lifecycle assessment to maximize reuse of materials and reduce carbon footprint of interventions.

Ascione, de Rossi, \& Vanoli, (2011) consider energy savings and economic benefit in their methodology. This study collected data from heat flux sensors, calibrated to historical monthly data, and simulated individual retrofit options. Then the most viable retrofits were combined to predict the total savings. A cost analysis was conducted for all the retrofit options. A similar approach is used in this study, but a simple payback is calculated to consider cost.

Adhikari et al. (2011) proposes a procedure for modelling and simulating energy performance of HBs: documenting the building, calculating thermal transmittance of walls, climate and microclimate data, model calibration using measured indoor air temperature, and then simulation. Alongi et al. (2015) conducted a detailed performance analysis of an historic castle in Italy and described their modelling and simulation methodology using TRNSYS, but there was no calibration method explained. Roberti, Oberegger, and Gasparella (2015) start with a detailed initial model based on energy data of the building, a sensitivity analysis, calibration to indoor air temperatures, and validation of the 
calibration. The importance of the calibration is to determine values for the most sensitive parameters in the model.

Grytli et al. (2014) outline a methodology and case study that assesses retrofits based on their environmental impacts and their impact on heritage values. Their approach focused on the heritage assessment from archival analysis, to surveying, condition assessment, values assessment, and life cycle assessment in addition to the energy assessment, which was not seen in many other papers that considered energy retrofits in HBs. For the heritage assessment, a numerical ranking was given based on how an intervention would impact the heritage values of the building. A single methodology that combines the strengths of the above methodologies, while being simple enough for a high adoption rate would be useful for achieving carbon reductions in historic buildings at scale.

\subsection{Embodied Carbon}

Demonstrating that great energy savings can be achieved and saying that "the greenest building is... one that is already built," is not enough on its own as the driver of climate change is the increase in greenhouse gas emissions (Elefante, 2017). The avoided carbon equivalent emissions should also be demonstrated when analysing a retrofit to determine its benefit over a period. Schulte, (2018) urges that embodied carbon of existing structures should be recognized as well as the protection of unique characteristics of heritage buildings.

A study comparing the carbon emissions mitigated through a net positive renovation of an existing building vs a new conventional building constructed to code showed that the reuse of the existing building mitigated $70 \%$ of the embodied carbon of the new building (Ecological Building Network, 2015). The study demonstrates the importance of the time 
value of carbon since $70 \%$ of emissions are mitigated from the very beginning of the building's reuse due to savings in the manufacturing of new materials. Another study showed that there is a potential for $55-83 \% \mathrm{CO}_{2}$ emissions savings when historic buildings are retrofitted using the Passive House Planning Package and renewables such as PVs are implemented (Moran, Blight, Natarajan, \& Shea, 2014). A case study done by Ferriss (2019) on the carbon payback timeline of a new construction vs renovating the existing building, shows that the payback of the new construction performing $65 \%$ better than code is about 30 years. If this scenario takes place in 2020 , then the new construction will not have contributed to greenhouse gas emissions reductions until 2050 when we are supposed to achieve a $99 \%$ reduction in carbon emissions from the existing building stock. There is a need for more studies on the avoided carbon of building reuse and retrofit to higher energy efficiency levels. For this reason, the research presented here also includes a life cycle carbon analysis of the energy retrofits.

\subsection{Problem Definition}

The issue for heritage and energy retrofit professionals is that there is no standard process for conducting a deep energy retrofit analysis for heritage buildings in order to respect the heritage values of these buildings while achieving great energy and carbon savings.

\subsubsection{Motivation}

The motivation of the research presented in this thesis is to help mitigate the climate change effects due to anthropogenic greenhouse gas emissions. Retrofitting existing buildings is a pathway to achieve great carbon emissions reductions. There is still a lot of push back from heritage conservationists about which retrofits may be done within heritage buildings. Toshiyuki Kono, president of ICOMOS (International Council on Monuments and Sites), 
advises that, "it would be foolish to imagine the practice of heritage remaining static while the world goes through the rapid and far-reaching transitions discussed in the IPCC's recent Special Report on Global Warming of $1.5^{\circ} \mathrm{C}$," (ICOMOS, 2019). Heritage professionals have the fundamental knowledge and values in stewardship, conservation and community to help drive climate action, but the majority are not facilitating this effort.

\subsubsection{Research Objectives and Contributions of Research}

This research is meant to provide a methodology and decision framework to help heritage and building professionals leverage heritage buildings to achieve great reductions in greenhouse gas emissions in historic single detached residential buildings. The methodology and decision framework can be used on other building archetypes. The approach is exemplified using a case-study heritage house.

This thesis aims to combine the many critical elements described in the literature review of methodologies to present one cohesive general methodology for conducting deep energy retrofits in historic buildings, while considering other important aspects (occupant comfort, cost, etc.). The general methodology is presented below in Figure 1. The application of the methodology is demonstrated for an historic wood framed house in Ottawa, Canada, where there are minimal studies considering heritage values and energy savings in a similar region and climate. The methodology delineates the creation of a calibrated energy model for an $\mathrm{HB}$ without invasive time-consuming testing and an appropriate level of documentation by leveraging the use of calibration to measured data. A decision framework (Figure 26) is presented to guide decision making for balancing the trade-offs between heritage conservation and energy savings objectives. While this study is conducted on a single-detached home, the goal is that this methodology and decision 
framework can be broadly applicable to most types of existing buildings. The selection of viable retrofit options requires the consideration of many different topics, such as heritage impact, cost, hygrothermal, occupant comfort, and occupant disruption, so this step will require a multidisciplinary team to conduct the necessary analyses.

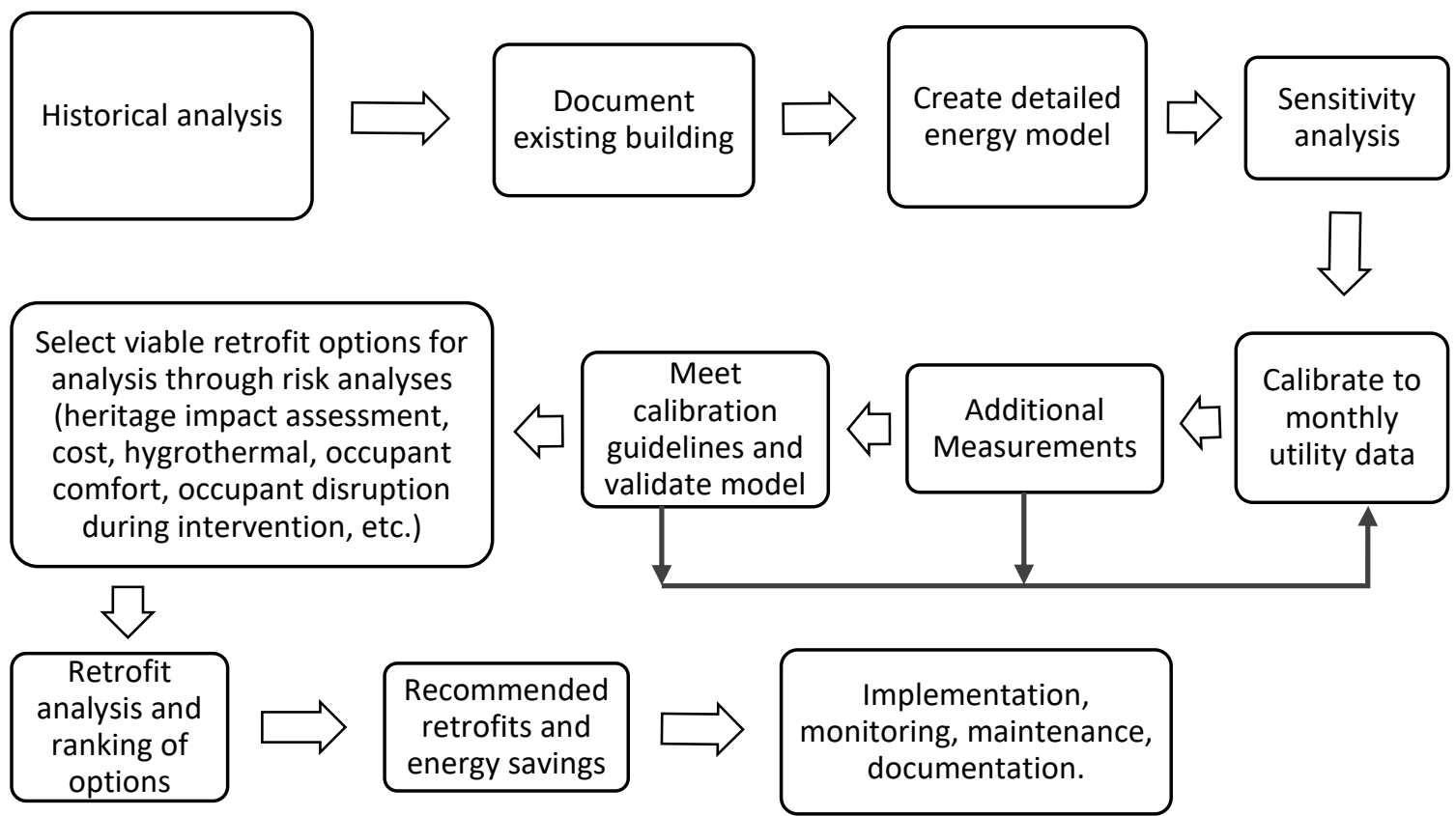

Figure 1: Proposed methodology for deep energy retrofit analysis in historic buildings. Size of step suggests relative amount of time to be spent. The process of additional measurements and re-calibration may be iterative. Validate the model using a different year of weather data and utility bill data if possible. 


\section{Case Study - Historical Analysis and Documentation}

A study was conducted on a residential home that is about 120 years old (built around 1898 to 1910) in the Glebe community (Keller-Herzog, 2018b), a mature neighbourhood ${ }^{3}$, in

Ottawa to provide recommendations for reducing the energy use and carbon footprint of the house. The addition of the house was likely added around 1956 based on historic aerial images from GeoOttawa. The house has $330 \mathrm{~m}^{2}$ of floor area and was recently recorded in its current state (floor plans, elevation drawing, condition report, photos, laser scanning, etc.) by a group of Carleton University students. A thorough condition assessment of the house was performed including indoor environmental quality (IEQ). This documentation was used to create accurate geometry of the case study house within energy modelling software. This model was created with as much detail as feasible to produce an accurate whole building simulation. The model was calibrated using utility bill data of the house and information obtained through an interview with the owner and survey of the site. The house is currently used as a bed and breakfast, a daycare for children, and home office. Since the house is old and contains many of the original materials, it is possible that this building may have heritage significance for its stakeholders. The following sections outline the historical analysis of heritage values of the site and the utility bill data analysis to understand the monthly energy use of the building.

\footnotetext{
${ }^{3}$ Mature neighbourhood overlay shown in GeoOttawa (http://maps.ottawa.ca/geoOttawa/). Historic map in GeoOttawa from 1928 shows the house on the lot already existed at this time. The City of Ottawa heritage study (2019) indicates three main eras of development in the Glebe as Early Development (17911890), Suburban Development (1891-1945), and Post-war Development (1946-present). It is likely that the construction of the original house occurred during the Suburban Development phase.
} 


\subsection{Understanding Heritage Values of the House}

There are not many designations in the Glebe neighbourhood so designating a significant house like this one may be important to conserve the architectural, associative, and environmental values of the 1950 s to the $21^{\text {st }}$ century. The Glebe Heritage Committee is also in the process of conducting historic research and submitting applications to designate the following areas in the Glebe: Clemow Avenue West, Monkland Avenue, Linden Terrace, and Central Park West (“Clemow Estate Phase II," 2016). There are exterior similarities between the houses found on the streets that have cultural value for the Glebe community and 166 Glebe avenue, the case study house, suggesting that this house may also be significant to the community (Figure 2).

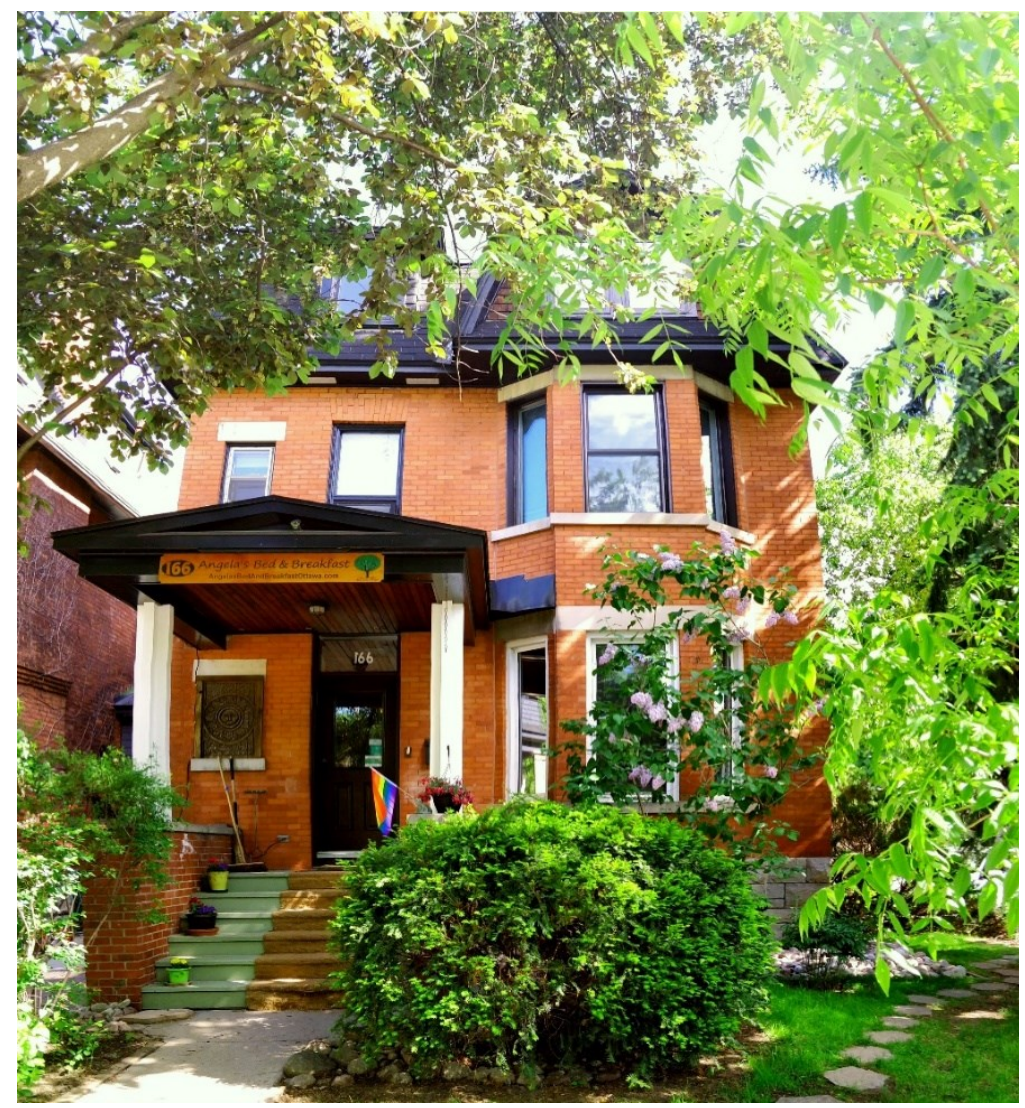

Figure 2: 166 Glebe Avenue, Ottawa. Angela's Bed and Breakfast. Located at the corner of Lyon street and Glebe avenue (Larissa Ide, June 2019). 
James Harvey Hopper was the architect of several expressive houses on the streets that the Glebe community has deemed to have significant heritage value (Elliott, 2011). Two houses on Glebe Avenue, designed by William D. Hopper architect and builder (James Hopper's brother), exhibit a combination of Dutch Colonial Revival and Queen Anne Revival architectural styles (Figure 3). These styles are also well pronounced in Angela's house and have similar features including: masonry details, stone foundation walls, portico, a front balcony (previously existed on the case study house), large bay windows, and dormer windows (Elliott, 2011). It is possible that the case study house was also designed by William Hopper or at least influenced by his designs because of the similarities. The two houses designed by William Hopper were later connected to become a row house that served as a senior's home for many years. Today this row house has retained its exterior front façade, but the back and interior have undergone major changes to be more modern (Elliott, 2011). This loss of heritage features provides a reason to protect the case study house which still contains original interior and exterior features.

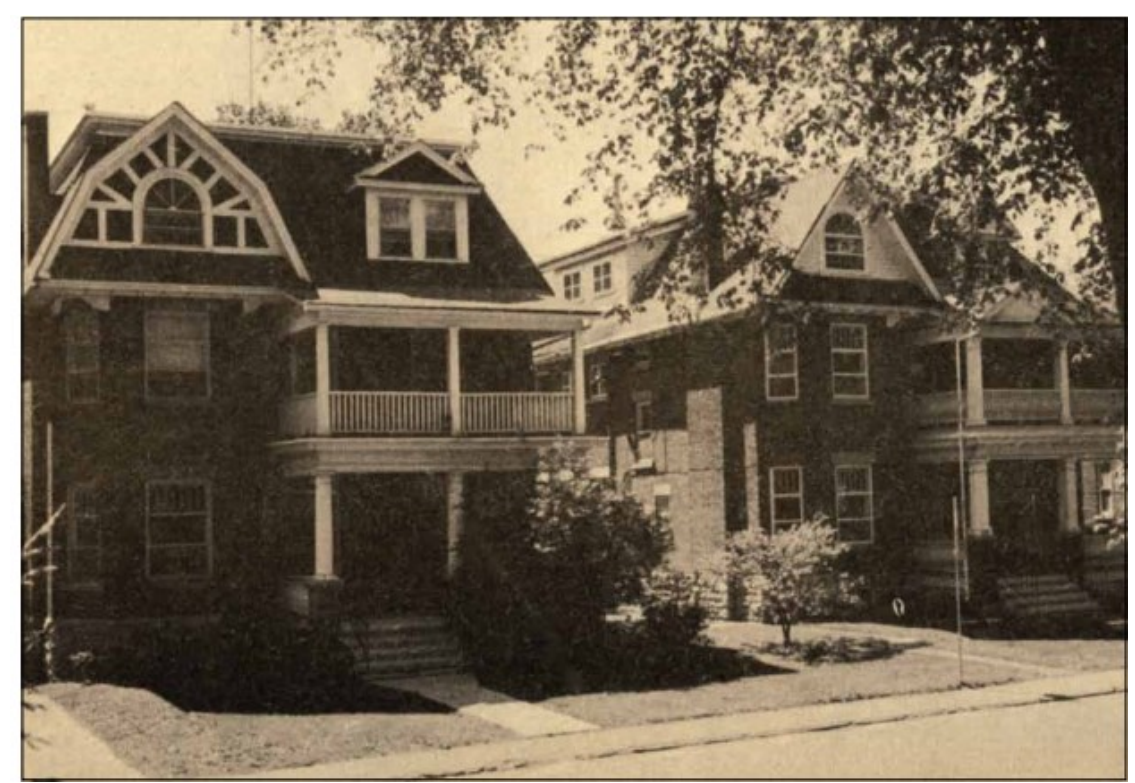

Figure 3: 174 and 176 Glebe Avenue, June 1974 (Elliott, 2011). 


\subsubsection{Current State and Future Intentions}

The case study house is currently kept in great condition as a result of fixing water shedding features of the house, repairing damaged mortar, adding insulation to the exterior walls and attic, air sealing the house, and the addition of steel support beams where settlement was occurring. Angela is a proactive house owner which is why the house is in such great condition. Several interior character-defining elements have also been preserved. The few elements of the house that are in poor condition are the basement door to the exterior and the wood shingles on the roof of the back addition of the house (Figure 4 and Figure 5).

The energy interventions as well as upgrades to appliances and water fixtures were conducted based on analyses from energy audit reports and thermography reports to improve the building's performance from an EnerGuide rating of 33 in 2012 to 67 in 2017 out of 100 (Belisle, 2017; Ferland, 2012). While this is a significant improvement, the owner is interested in reducing her carbon footprint as much as possible, which will entail reducing the heating load and improving the efficiency of the heating system, comprised of a gas boiler and iron radiators. Angela is also interested in adding an air-source heat pump for air-conditioning as the summers are getting hotter due to climate change. The goal of the energy analysis is to identify combinations of interventions that will achieve a $50 \%$ energy reduction in the house's energy use and reduce the carbon footprint as much as possible. 


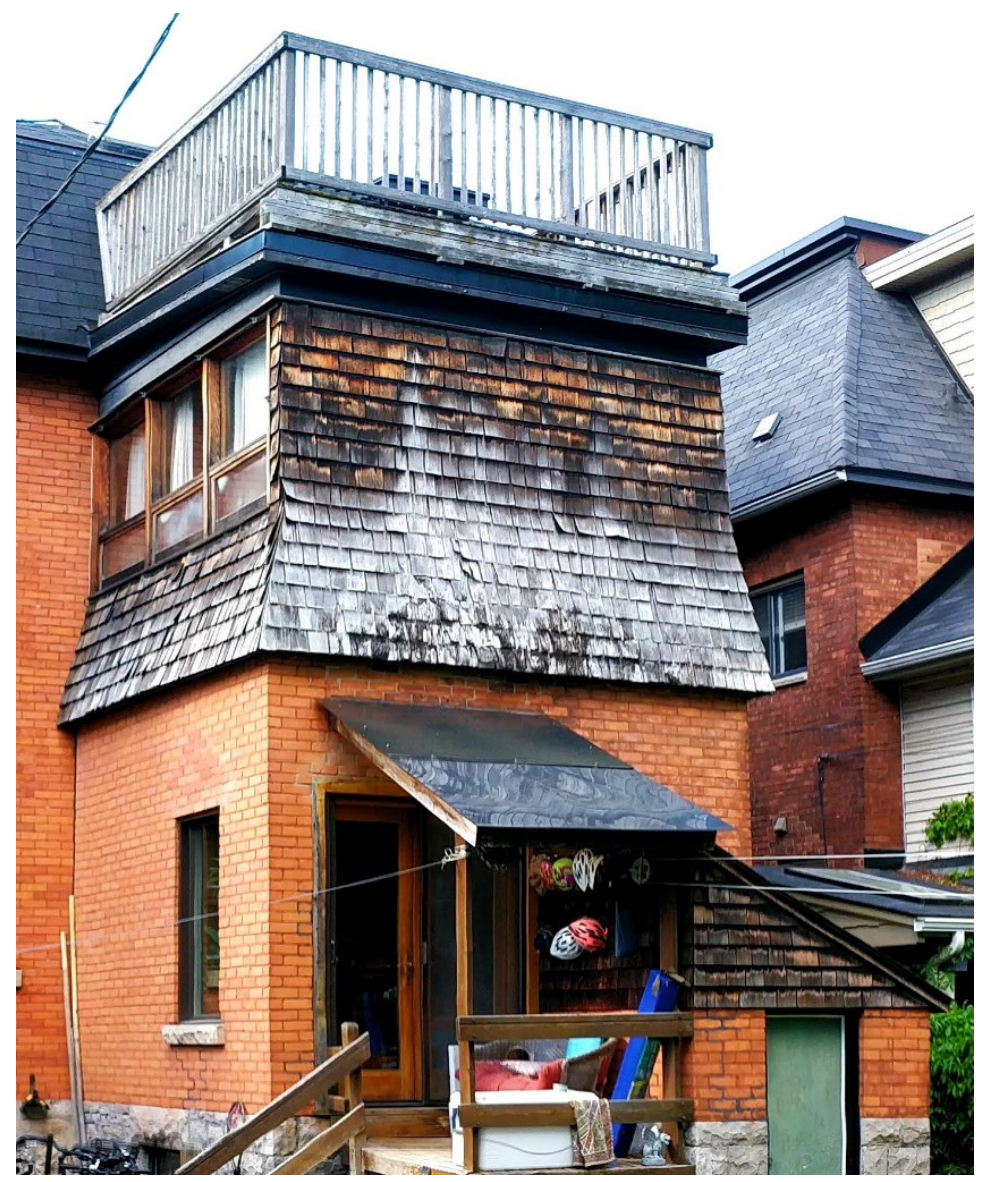

Figure 4: Rear view of case study house. Deteriorated wood shingles on roof of back addition to house (Larissa Ide, June 2019).

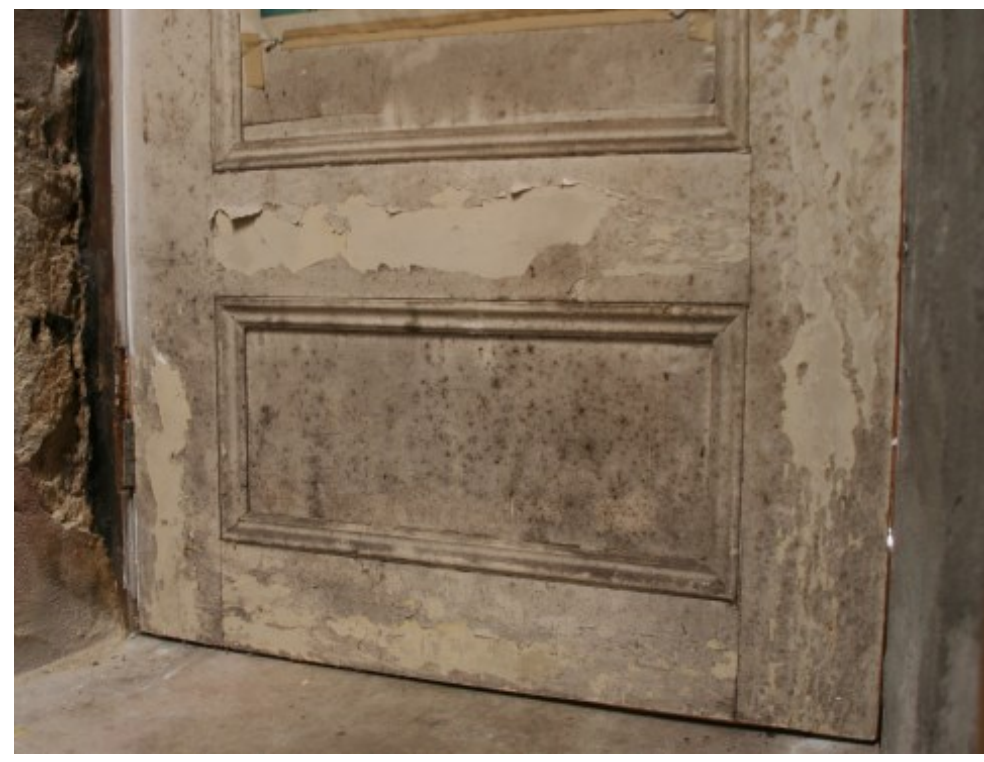

Figure 5: Basement door to exterior. Deterioration due to moisture: paint peeling and biological growth (Larissa Ide, June 2019). 


\subsubsection{Proposed Heritage Statement and Character Defining Elements}

Based on the historical analysis, the following heritage statement is proposed for 166 Glebe Avenue. Heritage significance is recognized in the house at 166 Glebe Avenue, constructed around 1898 to 1910, for its Dutch Colonial Revival and Queen Anne Revival architectural styles, its influence from prominent architects of the Glebe neighbourhood, James and William Hopper, the mature trees that surround the house which reflect the streetscape of Glebe avenue, its sustainability features, and the association with the current owner who is a community influencer through participation in several Glebe committees and programs. While this is not an extraordinary house, it is the modest nature, integration in the community, and example of the time it was built that make this house culturally significant. The character defining elements of the house were determined following guidelines in Parks Canada (2006) and Van Balen (2008). The Nara grid outlining key values of the place is provided in Table 2 .

The Nara grid is one way to assess the significance of a place and was chosen because it captures intangible and tangible values of a place (Van Balen, 2008). A rating for each element in the grid is given to indicate the level of significance as low, medium, high or very high. Older original elements that are unique to the style or character of the house have higher significance, while newer elements that may contribute to the newer values of the house have a lower significance. 
Table 2: Nara grid for case building. A rating of low, medium, high, or very high heritage significance has been assigned to each value.

\begin{tabular}{|c|c|c|c|c|c|}
\hline & Artistic & Historic & Social & Scientific & Photos \\
\hline $\begin{array}{l}\text { Form and } \\
\text { Design }\end{array}$ & $\begin{array}{l}\text { The mansard roof, } \\
\text { large bay windows, } \\
\text { and portico all } \\
\text { define the Dutch } \\
\text { Colonial and Queen } \\
\text { Anne Revival } \\
\text { architectural styles } \\
\text { of this house. } \\
\text { High }\end{array}$ & $\begin{array}{l}\text { The main house } \\
\text { area wood } \\
\text { framed structure } \\
\text { and external } \\
\text { cladding are the } \\
\text { original } \\
\text { structure from } \\
1889 \text { giving it } \\
\text { historical value. } \\
\text { High }\end{array}$ & $\begin{array}{l}\text { The addition of the } \\
\text { house reflects the styles } \\
\text { of the main house and } \\
\text { provide additional } \\
\text { spaces for the } \\
\text { permanent occupants } \\
\text { and guest of the house } \\
\text { facilitating its current } \\
\text { use as office space, a } \\
\text { daycare, and bed and } \\
\text { breakfast. } \\
\text { Medium }\end{array}$ & $\begin{array}{l}\text { The portico and strategic } \\
\text { placement of windows } \\
\text { provide shading and } \\
\text { protection from } \\
\text { environmental elements as } \\
\text { well as allow ample use of } \\
\text { daylight to light the interior } \\
\text { spaces. } \\
\text { High }\end{array}$ & 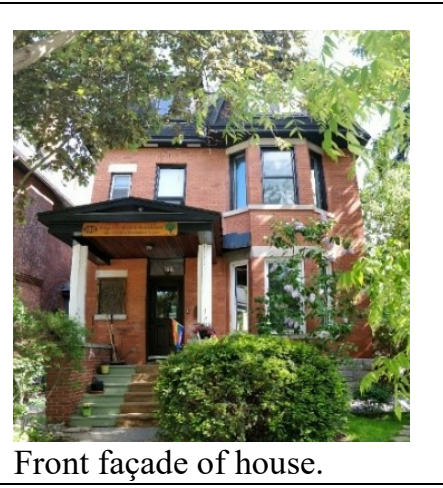 \\
\hline $\begin{array}{l}\text { Materials and } \\
\text { Substance }\end{array}$ & $\begin{array}{l}\text { Stone lintels } \\
\text { provide accents in } \\
\text { the aesthetic of the } \\
\text { brick masonry } \\
\text { façade. } \\
\text { High }\end{array}$ & $\begin{array}{l}\text { Stone } \\
\text { foundation, } \\
\text { stone lintels, red } \\
\text { brick, and wood } \\
\text { framing are } \\
\text { historic } \\
\text { materials } \\
\text { conserved on } \\
\text { this site. } \\
\text { High } \\
\end{array}$ & $\begin{array}{l}\text { The historic wood } \\
\text { mouldings and cast- } \\
\text { iron radiators provide } \\
\text { additional cultural } \\
\text { value on the interior of } \\
\text { the house. } \\
\text { High }\end{array}$ & $\begin{array}{l}\text { The durability and } \\
\text { repairability of the materials } \\
\text { used in this house (brick and } \\
\text { stone masonry, wooden } \\
\text { framed windows, and wood } \\
\text { structural elements) provide } \\
\text { examples of quality historic } \\
\text { materials. } \\
\text { High }\end{array}$ & $\begin{array}{l}\text { Fully pitched scotch bond } \\
\text { masonry foundation. }\end{array}$ \\
\hline $\begin{array}{l}\text { Use and } \\
\text { Function }\end{array}$ & $\begin{array}{l}\text { The chimney and } \\
\text { fireplace were } \\
\text { historically used to } \\
\text { heat the home, but } \\
\text { now serve as } \\
\text { decorative } \\
\text { elements. } \\
\text { Medium }\end{array}$ & $\begin{array}{l}\text { The house has } \\
\text { historically been } \\
\text { used as a home } \\
\text { and continues to } \\
\text { be a home to the } \\
\text { owner of the } \\
\text { house. } \\
\text { Medium }\end{array}$ & $\begin{array}{l}\text { The use of the house as } \\
\text { a daycare and bed and } \\
\text { breakfast add social } \\
\text { value to the building by } \\
\text { bringing together a } \\
\text { wide variety of } \\
\text { demographics that pass } \\
\text { through this house. } \\
\text { Medium }\end{array}$ & $\begin{array}{l}\text { Water shedding features } \\
\text { were repaired to reduce } \\
\text { moisture damage on the } \\
\text { exterior of the building. } \\
\text { Mortar was repointed where } \\
\text { damage was incurred. } \\
\text { Repairing these historic } \\
\text { materials fulfill the } \\
\text { important protective and } \\
\text { sheltering functions of the } \\
\text { building envelope. } \\
\text { High }\end{array}$ & $\begin{array}{l}\text { Interior view of brick chimney } \\
\text { and fireplace. }\end{array}$ \\
\hline
\end{tabular}




\begin{tabular}{|c|c|c|c|c|c|}
\hline & Artistic & Historic & Social & Scientific & Photos \\
\hline $\begin{array}{l}\text { Tradition, } \\
\text { techniques, } \\
\text { and } \\
\text { workmanship }\end{array}$ & $\begin{array}{l}\text { The fully pitched } \\
\text { scotch bond masonry } \\
\text { used in the } \\
\text { foundation are a } \\
\text { beautiful element of } \\
\text { the aesthetic value of } \\
\text { the building and } \\
\text { demonstrate the high } \\
\text { level of } \\
\text { craftsmanship. } \\
\text { High }\end{array}$ & $\begin{array}{l}\text { Historic } \\
\text { decorated } \\
\text { radiators also } \\
\text { demonstrate the } \\
\text { amount of detail } \\
\text { and } \\
\text { workmanship } \\
\text { that went into } \\
\text { this house. } \\
\text { Medium }\end{array}$ & $\begin{array}{l}\text { The high quality of } \\
\text { workmanship throughout } \\
\text { the house increase the } \\
\text { place's value to the } \\
\text { community. The current } \\
\text { energy conscious features } \\
\text { such as the solar PVs add } \\
\text { the social value of being } \\
\text { an example of reducing } \\
\text { one's impact on the planet. } \\
\text { High }\end{array}$ & $\begin{array}{l}\text { The exposed wood } \\
\text { structural frame in the } \\
\text { basement exhibit the } \\
\text { techniques used in the } \\
\text { construction of the } \\
\text { building. The wood } \\
\text { balloon framing of the } \\
\text { house is a traditional } \\
\text { technique for } \\
\text { constructing houses of } \\
\text { this age with quality } \\
\text { timber. } \\
\text { Medium }\end{array}$ & $\begin{array}{l}\text {-iron radiators used to heat } \\
\text { ouse. }\end{array}$ \\
\hline $\begin{array}{l}\text { Location and } \\
\text { setting }\end{array}$ & $\begin{array}{l}\text { The architectural } \\
\text { style of the house } \\
\text { reflects the styles of } \\
\text { many houses in the } \\
\text { Glebe community, } \\
\text { contributing to a } \\
\text { cohesive urban } \\
\text { landscape. } \\
\text { High }\end{array}$ & $\begin{array}{l}\text { The house was } \\
\text { designed or } \\
\text { influenced by } \\
\text { historic } \\
\text { architects of the } \\
\text { area James and } \\
\text { William Hopper } \\
\text { evidenced by its } \\
\text { age and style. } \\
\text { Low }\end{array}$ & $\begin{array}{l}\text { The house is in a walkable } \\
\text { community, situated close } \\
\text { to Bank street, a main } \\
\text { street that constitutes many } \\
\text { local stores, increasing its } \\
\text { social value. Because of its } \\
\text { connection to Glebe } \\
\text { Community leader, the } \\
\text { location on Glebe Avenue } \\
\text { is significant. } \\
\text { Medium }\end{array}$ & $\begin{array}{l}\text { Many mature } \\
\text { deciduous trees } \\
\text { strategically placed on } \\
\text { the site provide } \\
\text { necessary shading } \\
\text { during the summer to } \\
\text { reduce solar gains } \\
\text { within the house. } \\
\text { High }\end{array}$ & $\begin{array}{l}\text { rees providing shade } \\
\text { ummer. }\end{array}$ \\
\hline $\begin{array}{l}\text { Spirit and } \\
\text { feeling }\end{array}$ & $\begin{array}{l}\text { The similar aesthetic } \\
\text { of the house to other } \\
\text { houses in the } \\
\text { neighbourhood } \\
\text { contribute to the } \\
\text { feeling of community } \\
\text { that is tied with the } \\
\text { current owner's } \\
\text { commitment to a } \\
\text { greater good. } \\
\text { Medium }\end{array}$ & $\begin{array}{l}\text { The good state } \\
\text { of the } \\
\text { conservation of } \\
\text { the historic } \\
\text { structure, } \\
\text { materials, and } \\
\text { elements portray } \\
\text { the age and } \\
\text { significance of } \\
\text { the building. } \\
\text { High }\end{array}$ & $\begin{array}{l}\text { The place provides a sense } \\
\text { of community, due to the } \\
\text { welcoming porch steps and } \\
\text { LGBTQ flag in front. } \\
\text { Angela Keller-Herzog, the } \\
\text { owner of the house, is a } \\
\text { community leader in } \\
\text { climate action. } \\
\text { Medium }\end{array}$ & $\begin{array}{l}\text { The use of advanced } \\
\text { technologies on the site } \\
\text { (solar PVs) help create } \\
\text { the spirit of the place } \\
\text { being respectful of its } \\
\text { surrounding } \\
\text { environment by } \\
\text { reducing its energy use } \\
\text { for the operation of the } \\
\text { building. } \\
\text { Low }\end{array}$ & de of house. \\
\hline
\end{tabular}




\subsection{Utility Bill Data Analysis}

\subsubsection{Heating Degree Day Analysis}

As part of the historical analysis of the building, past utility bill data should be analysed and annual energy use $\left(\mathrm{kWh} / \mathrm{m}^{2}\right)$ should be compared to similar aged buildings and newer buildings with the same construction type. Knowing the heritage values, condition, and comparative energy use intensity of the house will help determine a realistic energy reduction target. For comparison, space heating energy statistics were analysed because this was the most complete data and it consumes the most energy in residential buildings in Canada. The oldest most complete data in Canada for buildings constructed in 1990 shows that the space heating energy use is $206 \mathrm{kWh} / \mathrm{m}^{2}$ for Ontario (NRCan, 2016). The average space heating for buildings constructed in $2011-2016$ is $133 \mathrm{kWh} / \mathrm{m}^{2}$ for Ontario.

The measured gas and electricity data from utility bills for 2015 to 2017 are shown in Figure 6 . The average annual electricity use is $40 \mathrm{kWh} / \mathrm{m}^{2}$ (24\% of total) for lighting, appliances and a small portion for pumps used in the hydronic heating system ${ }^{4}$. The electricity use does not have much variation throughout the year because of its type of usage (mostly appliances and lighting). There is a slight increase in electricity use during the summer due to an increase in guests during that time. The average annual gas use is $128 \mathrm{kWh} / \mathrm{m}^{2}$ (76\% of total) for the gas boiler used for heating and a tankless gas heater for the domestic hot water (DHW). The gas use increases for the heating season and decreases for the cooling season when it is only used for DHW. A heating degree day analysis was

\footnotetext{
${ }^{4}$ Note: The power generated by the existing PVs on site is not included in the baseline EUI of the house since PV calculations are done outside of the detailed energy model to be calibrated. There is no air conditioning or mechanical ventilation in this house.
} 
conducted for the gas energy use since it is mostly used for heating (Figure 7). HDD is calculated using the following equation:

$$
H D D=\sum\left(T_{\text {bal }}-T_{\text {out }}\right) \quad(\text { eq. } 1)
$$

Where $T_{b a l}$ is the balance temperature which is the outdoor temperature at which no heating is required; $T_{\text {out }}$ is the average temperature for each day of the year; the HDD for each day can not be negative (zero if it calculates to be negative); and this is summed for the entire year. Only monthly utility bill data was available, so the calculation was done on a monthly basis (instead of hourly) and summed for the year. A regression was conducted to determine what portion of the gas energy use was not correlated to the required heating for the house, therefore indicating the energy use for the DHW. The coefficient of determination is 0.876 ; since this is an older home with a building envelope that allows more airflow, the performance of the house is more dependent on the outdoor temperature than a newer building that has a more air-tight envelope. This regression analysis also gave the baseload of $1.7 \mathrm{kWh} / \mathrm{m}^{2}$ per month and about $20 \mathrm{kWh} / \mathrm{m}^{2}$ per year which corresponds to the DHW use. This means that space heating is about $108 \mathrm{kWh} / \mathrm{m}^{2}$ which is $47 \%$ and 19\% better than Ontario's 1990 and 2011-2016 space heating energy use for residential buildings, so this house is already performing better than many houses. 


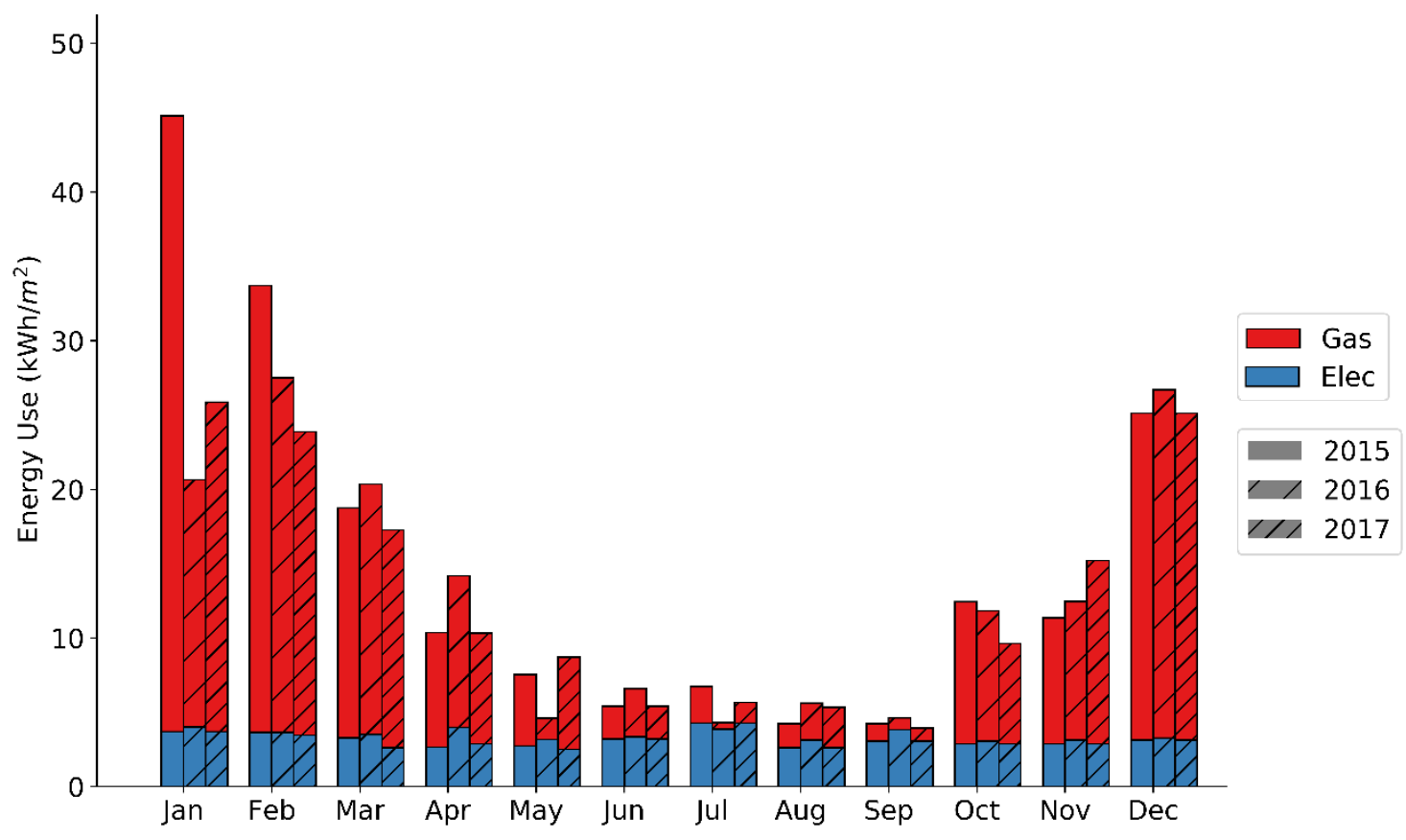

Figure 6: Measured gas and electricity consumption for 2015-2017. May to August have higher occupancy due to guests in bed and breakfast, resulting in greater DHW consumption than the estimated baseload. Electricity use is greatest in July because of several personal fans during hottest month (no air-conditioning in the house).

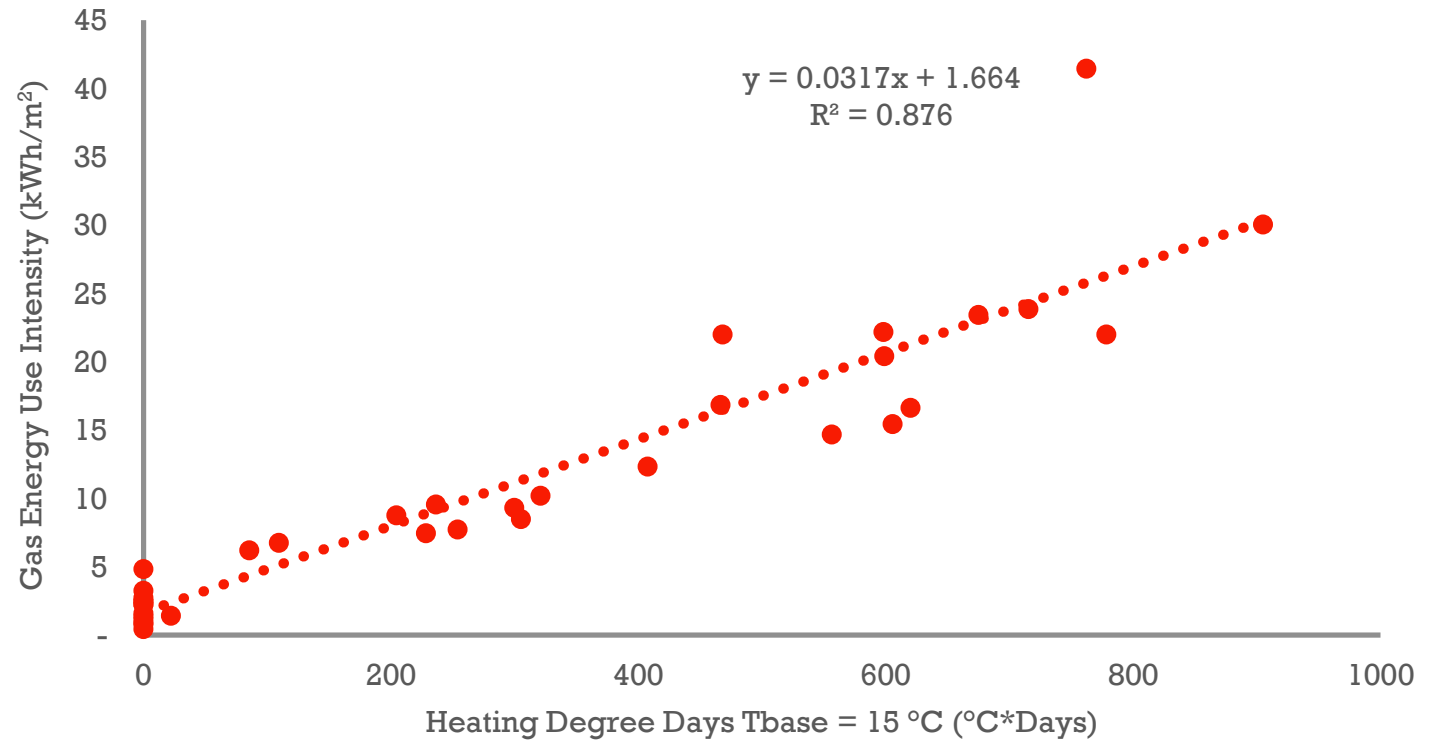

Figure 7: Heating degree day analysis for the house with a base temperature of $15^{\circ} \mathrm{C}$. Estimated baseload DHW energy use is $1.7 \mathrm{kWh} / \mathrm{m}^{2} /$ month and $20.4 \mathrm{kWh} / \mathrm{m}^{2} /$ year. 


\subsubsection{Current PV Power Generation}

The site also has some solar photovoltaic panels on the roof of the house and detached garage that generate power to offset the electricity consumption. The energy generated by the PVs is supplied to the grid and is credited on the electricity energy bill. The PV generation for 2015-2017 (Figure 8) shows that there is significantly more PV generation during the summer than in the winter as expected because of the greater number of overcast days in the winter and the lower solar altitude of the sun in the winter. The annual total PV power generation for 2015, 2016 and 2017 are $11.6 \mathrm{kWh} / \mathrm{m}^{2}, 11.9 \mathrm{kWh} / \mathrm{m}^{2}$, and 10.8 $\mathrm{kWh} / \mathrm{m}^{2}$. The data shows that the average PV power generation has been quite consistent from $2015-2017$ at around $31 \%\left(11.4 \mathrm{kWh} / \mathrm{m}^{2}\right)$ of the annual electricity consumption.

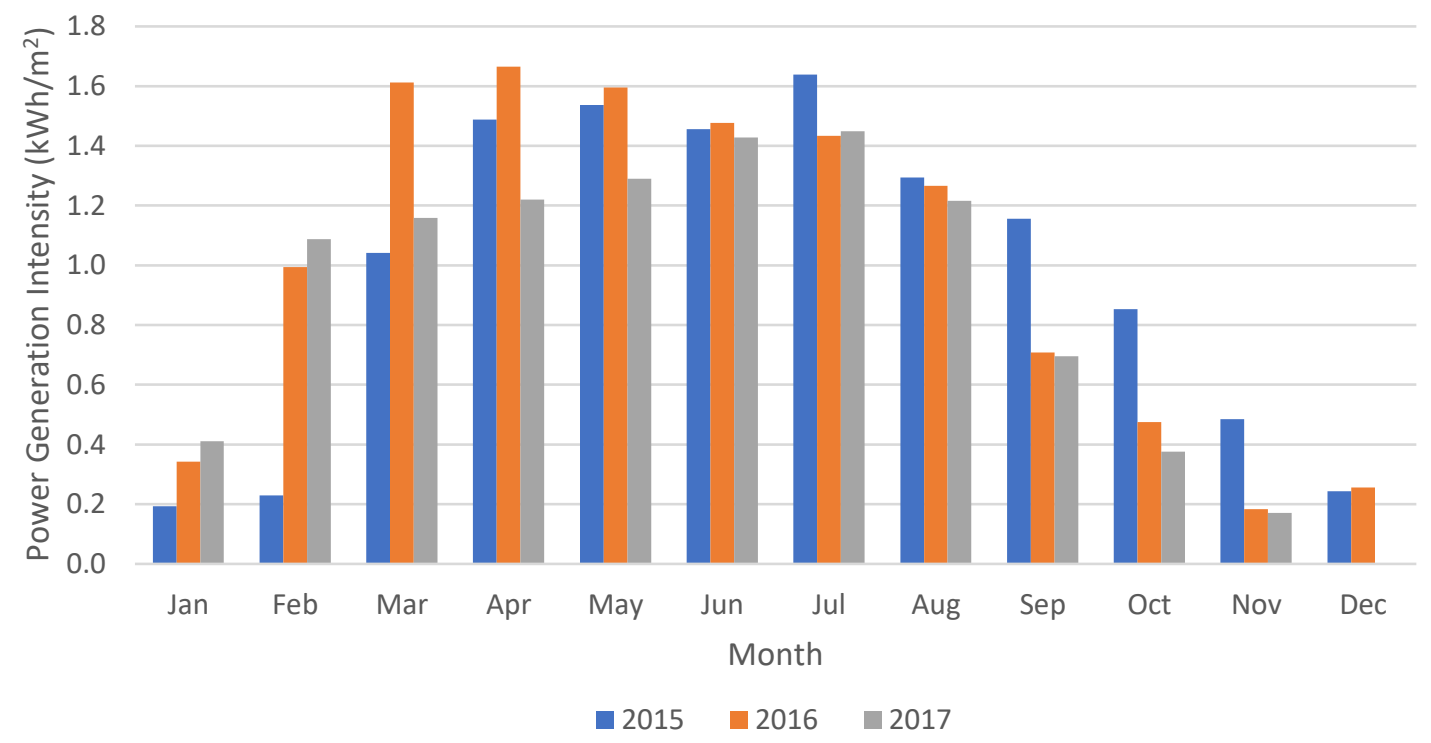

Figure 8: Current PV power generation intensity in $\mathrm{kWh} / \mathrm{m}^{2}$ for 2015-2017. The average electricity generation is about $2.7 \mathrm{kWh} / \mathrm{m}^{2} /$ year. 


\section{Detailed Energy Model}

\subsection{Methodology}

A detailed energy model was created using OpenStudio and EnergyPlus ${ }^{5}$ (EnergyPlus, 2018; OpenStudio, 2018). To achieve a deep energy retrofit, multiple retrofits need to be combined, and a simple model will not predict the interactions of multiple retrofits. First, a representation of the geometry of the building (see Figure 9) was created using floor plans (see Appendix A) and elevation drawings that were recorded in 2018. All sides of the final building model are shown in Appendix B.

Simplifications were made for the geometry as the geometric resolution does not significantly impact the simulation results for the purposes of this study. This improves reproducibility, reduces model complexity and simulation run time, while keeping the necessary data. The simplifications made were: modelling smaller dormer windows as inplane windows, creating a flat roofed third floor/attic with an equivalent volume as the mansard roof attic (the existing roof has a small slope), and using an average floor area to have a consistent footprint for each floor (no small overlaps in floors). Shading by trees (deciduous and evergreen) was represented in the model to account for reduction in solar radiation, daylighting, wind and change in longwave radiation to environment. Thermal zones were separated by floor and by the different constructions of the house (main part of house separated from more recent addition), resulting in seven thermal zones in total.

\footnotetext{
${ }^{5}$ Software was chosen because it has been tested and validated using the BESTest (DOE, 2020).
} 
Separating the house into these thermal zones allows for adjustments in each individual thermal zone as necessary to match the behaviour of the existing house.
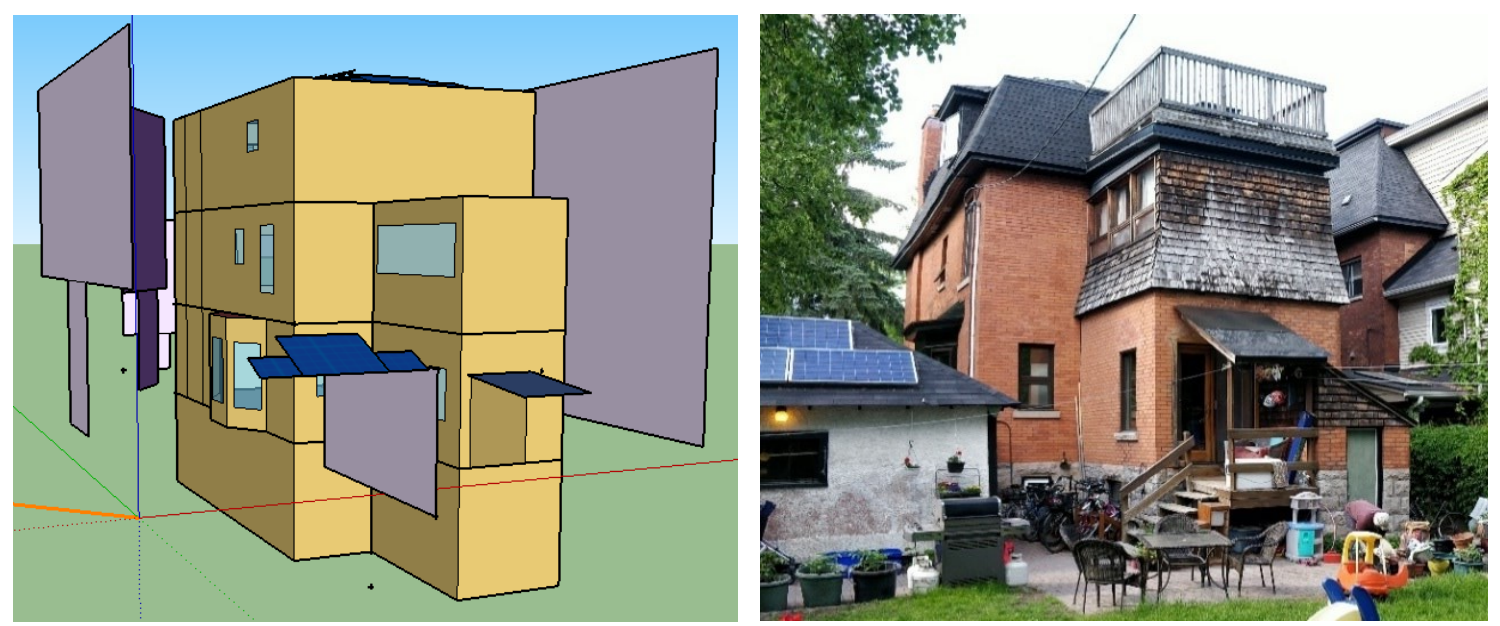

Figure 9: Geometry of model in SketchUp plug-in and view of back of house from the same perspective (Larissa Ide, June 2019). Purple/gray shading objects are used to represent trees and adjacent building.

The schedules, plug loads, occupancy, and HVAC were defined for the model based on information obtained from an interview with the house owner and survey of the house. The average permanent occupancy for the calibration year was four occupants. Additionally, there are 5-10 children and one adult present during the day for the daycare that is run in the house. The occupancy varies throughout the year because of the guests that come for the bed and breakfast service in the house. The summer occupancy and DHW use are higher than the rest of the year due to increased number of guests. Unique schedules for occupancy, equipment and DHW were created based on this information instead of using ASHRAE recommended occupancy schedules. Figure 10 shows occupancy during holidays/Saturdays/Sundays. The typical occupancy was assumed to be 3.6. The occupancy reduces for a few hours during the morning, assuming that occupants may need/want to leave for errands or other things. The figure below also shows the occupancy schedule for a weekday (Monday to Friday); it starts at the typical occupancy and increases 
to 6 people to account for the daycare provider and children for the daycare. Then at $5 \mathrm{pm}$, the daycare service ends, and the occupancy returns to the regular level. Additional details about the internal gains inputs are provided in Appendix B.
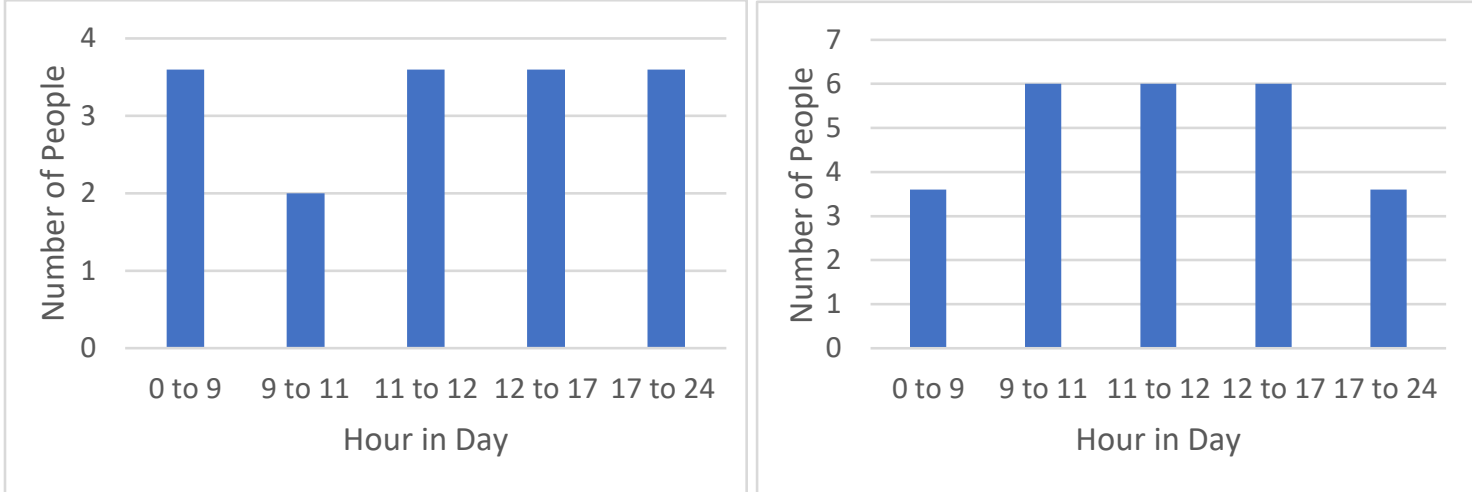

Figure 10: Occupancy schedule for holidays (left). Assumed Jan 1-5 and Dec 25-31 were typical holidays. Occupancy for weekdays Jan 6-Dec 24 (right).

To ensure that model inputs were correct, and the model was behaving as expected, outputs were examined for specific inputs. For example, when shading objects were added and schedules were assigned to represent deciduous trees, the incident solar radiation on exterior building surfaces were compared before and after adding shading devices and during winter or summer months.

The temperature setpoint for heating was initially set at $21^{\circ} \mathrm{C}$ because of the setpoint on the thermostats. The radiant hydronic heating system was modelled using a baseboard radiant convective water system. A baseboard radiator was assigned to each conditioned space. The radiators were connected to the gas boiler with a water outlet temperature of $82^{\circ} \mathrm{C}$ indicated by the boiler. The initial air infiltration was modelled using the calculated flow coefficients based on air changes per hour measured in a blower door test in 2017 which indicated $11 \mathrm{ACH}$ at $50 \mathrm{~Pa}$. The method used to calculate the air infiltration for the house in the energy model was the AIM-2 model by Walker \& Wilson, (1998) which is 
appropriate for smaller, residential buildings. The flow coefficient was calculated using the equation in the AIM-2 model rearranged:

$$
\mathrm{C}=\mathrm{Q} / \Delta \mathrm{P}^{\mathrm{n}} \quad(\text { eq. } 2)
$$

Where $\mathrm{Q}$ is the air infiltration flow rate $\left(\mathrm{m}^{3} / \mathrm{s}\right), \mathrm{C}$ is the flow coefficient, $\Delta \mathrm{P}$ is the pressure difference between inside and outside (about 50 Pa for a blower door test), and $\mathrm{n}$ is the power law pressure-flow relationship assumed to be 0.67 (EnergyPlus Version 8.9 Documentation Input Output Reference, 2018). Air changes per hour were converted to flow coefficients using equation 1 and the following equation to convert $\mathrm{ACH}$ to $\mathrm{m}^{3} / \mathrm{s}$.

$$
\mathrm{Q}\left(\mathrm{m}^{3} / \mathrm{s}\right)=\mathrm{ACH}^{*} \mathrm{~V}_{\text {space }} / 3600 \mathrm{~s} / \mathrm{h}
$$

$V_{\text {space }}$ is the volume of the space in $\mathrm{m}^{3}$. The flow coefficients for each of the seven thermal zones were calculated for each iteration of total ACH for the house and weighted $20 \%$ basement, $20 \%$ ground floor, $20 \%$ level 1, and $40 \%$ level 2 based on the patterns observed in thermography. The equation below is how the air infiltration is calculated in EnergyPlus using the ZoneInfiltration:FlowCoefficient class:

$$
\text { Infiltration }=\left(F_{\text {Schedule }}\right) \sqrt{\left(c C_{s} \Delta T^{n}\right)^{2}+\left(c C_{w}(s * \text { WindSpeed })^{2 n}\right)^{2}}
$$

Where:

- $\quad F_{\text {schedule, }}$ fractional schedule multiplier $=1$

- $c$, flow coefficient, was calculated using eq. 2

- $C_{S}$, stack coefficient $=0.107$ for three storey house with flue (ASHRAE 2017) 
- $\Delta T$, average temperature difference between the indoor zone air and outdoor air, calculated during simulation

- $n$, pressure exponent, was assumed to be a typical value of 0.67

- $C_{w}$, wind coefficient $=0.167$ for three storey house with a basement and flue (ASHRAE 2017)

- $s$, shelter factor $=0.6$ for an urban building on a larger lot (less than 0.61 shelter factor for typical urban building on larger lot because only sheltered on one side since it is a corner site)

\subsection{Results and Analysis}

The zone operative air temperature was checked to see if temperature setpoints were being met. It was found that the gas radiators in the model were not heating the space to the $21^{\circ} \mathrm{C}$ temperature setpoint. It seemed that the radiators were under sized at $75 \mathrm{~W} / \mathrm{m}^{2} \max$ capacity each by the software potentially due to the high air infiltration modelled (Figure 11). The zone temperature during the summer peaks around $38^{\circ} \mathrm{C}$ because air flow networks were not used to model the natural ventilation used for cooling. The reason for this was because this level of complexity did not seem necessary for the purposes of estimating the energy use and occupants had indicated overheating during the summer with the use of natural ventilation alone. When the baseboard capacity was increased to 105 
$\mathrm{W} / \mathrm{m}^{2}$, the zone operative air temperature was able to stay closer to $21^{\circ} \mathrm{C}$ than before (Figure 12) and the monthly energy use was closer to the measured 2017 utility data.

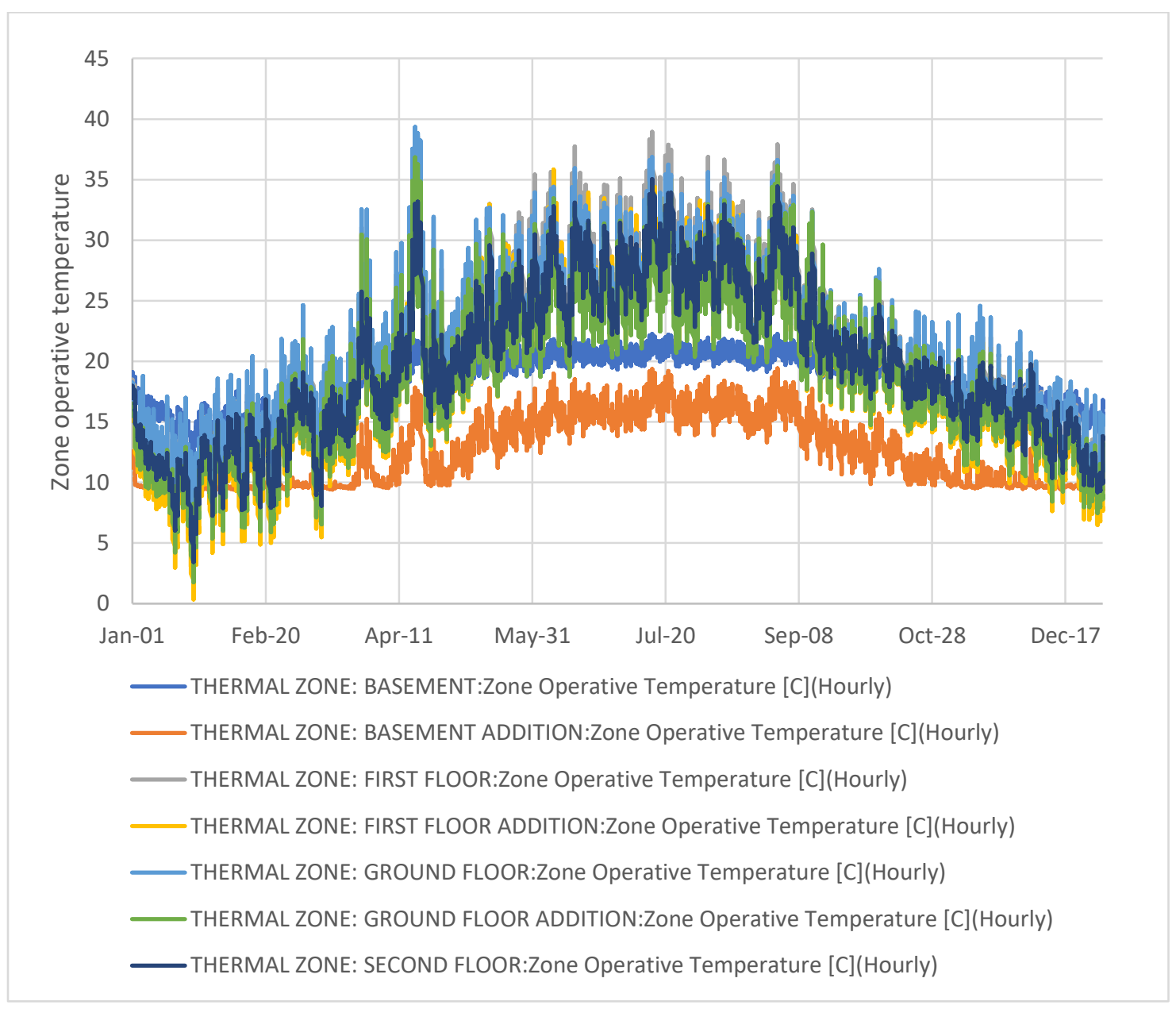

Figure 11: Zone operative air temperature with $75 \mathrm{~W} / \mathrm{m}^{2}$ capacity baseboard heaters for each zone. The zone air temperature drops far below the temperature setpoint of $21^{\circ} \mathrm{C}$ during the winter. 


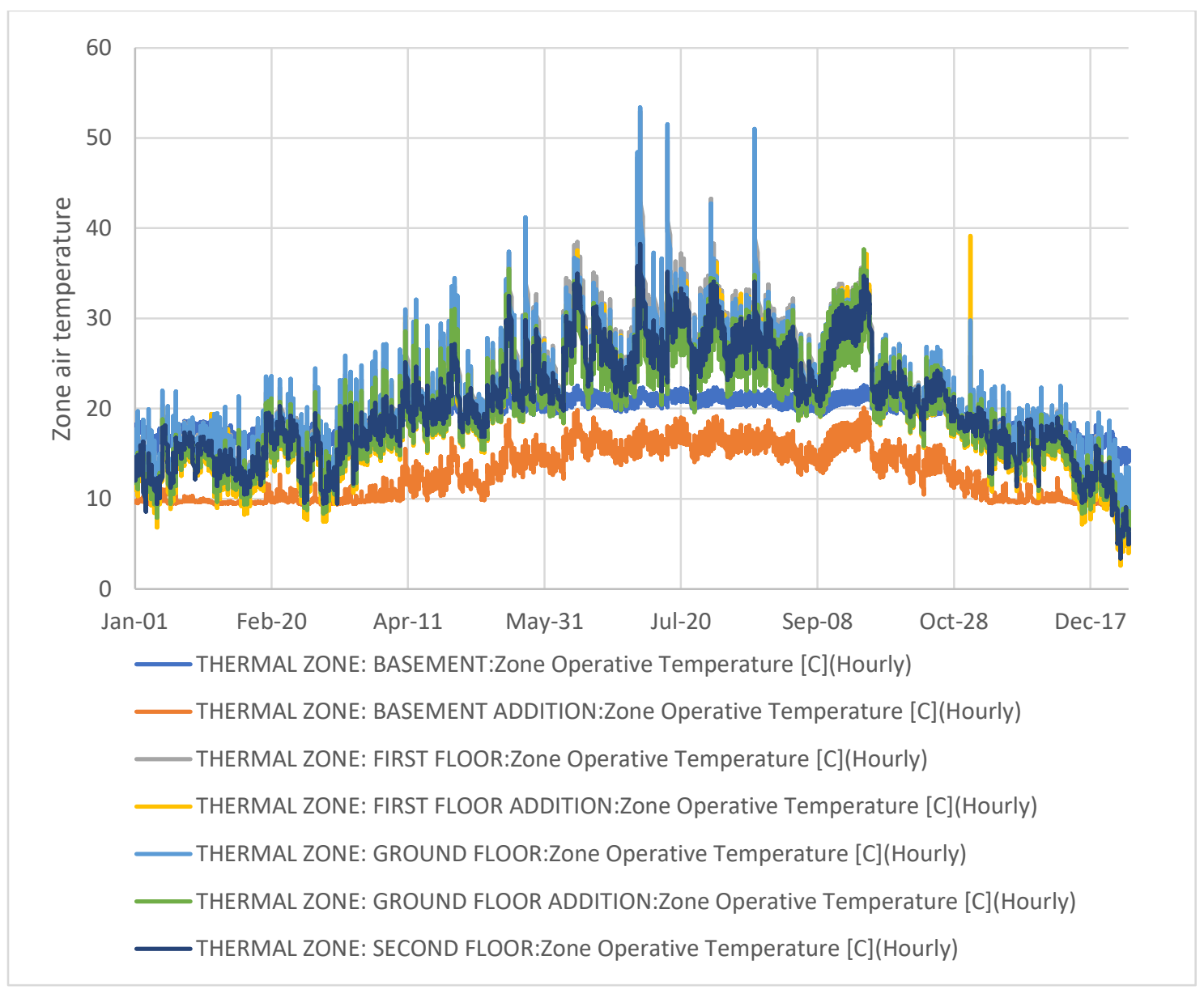

Figure 12: Zone operative air temperature with $105 \mathrm{~W} / \mathrm{m}^{2}$ capacity baseboard heaters for each zone. The zone air temperature drops below the temperature setpoint of $21^{\circ} \mathrm{C}$ during the winter.

The air infiltration was checked as well. The total air infiltration for the house was determined to be about $14 \mathrm{ACH}$ (air changes per hour) at $50 \mathrm{~Pa}\left(0.0078 \mathrm{~m}^{3} / \mathrm{s} / \mathrm{m}^{2}\right.$ at $50 \mathrm{~Pa}$ or $1.54 \mathrm{cfm} / \mathrm{ft}^{2}$ at $50 \mathrm{~Pa}$ ) based on the calibrated model. The air infiltration from the simulation is output in $\mathrm{ACH}$ at ambient conditions rather than at a $50 \mathrm{~Pa}$ difference. $\mathrm{A}$ rough estimate of the $\mathrm{ACH}$ at ambient conditions would be to divide the $\mathrm{ACH}$ at $50 \mathrm{~Pa}$ by 20, which is about $0.70 \mathrm{ACH}\left(0.00039 \mathrm{~m}^{3} / \mathrm{s} / \mathrm{m}^{2}\right.$ or $\left.0.83 \mathrm{cfm} / \mathrm{ft}^{2}\right)$. The air infiltration was distributed by floor level of $20 \%$ for the basement header, $20 \%$ for the ground floor, $20 \%$ for the first floor, and $40 \%$ for the header of the second floor. The air infiltration fluctuates 
with the windspeed and temperature difference between indoors and outdoors throughout the year.

Seen in Figure 13, the second floor air infiltration is an average of $0.31 \mathrm{ACH}$ over the entire year. The other zones have an average air infiltration ranging from $0.09 \mathrm{ACH}$ for the basement addition which has the smallest area above ground, to $0.16 \mathrm{ACH}$ for the first floor space. Other things that were checked were the change in solar radiation when adding PV arrays as shading objects, blinds for windows, lighting schedules, equipment schedules, and people schedules. Checking outputs helped determine if inputs were correct or if they needed to be improved to better represent the reality of the house.

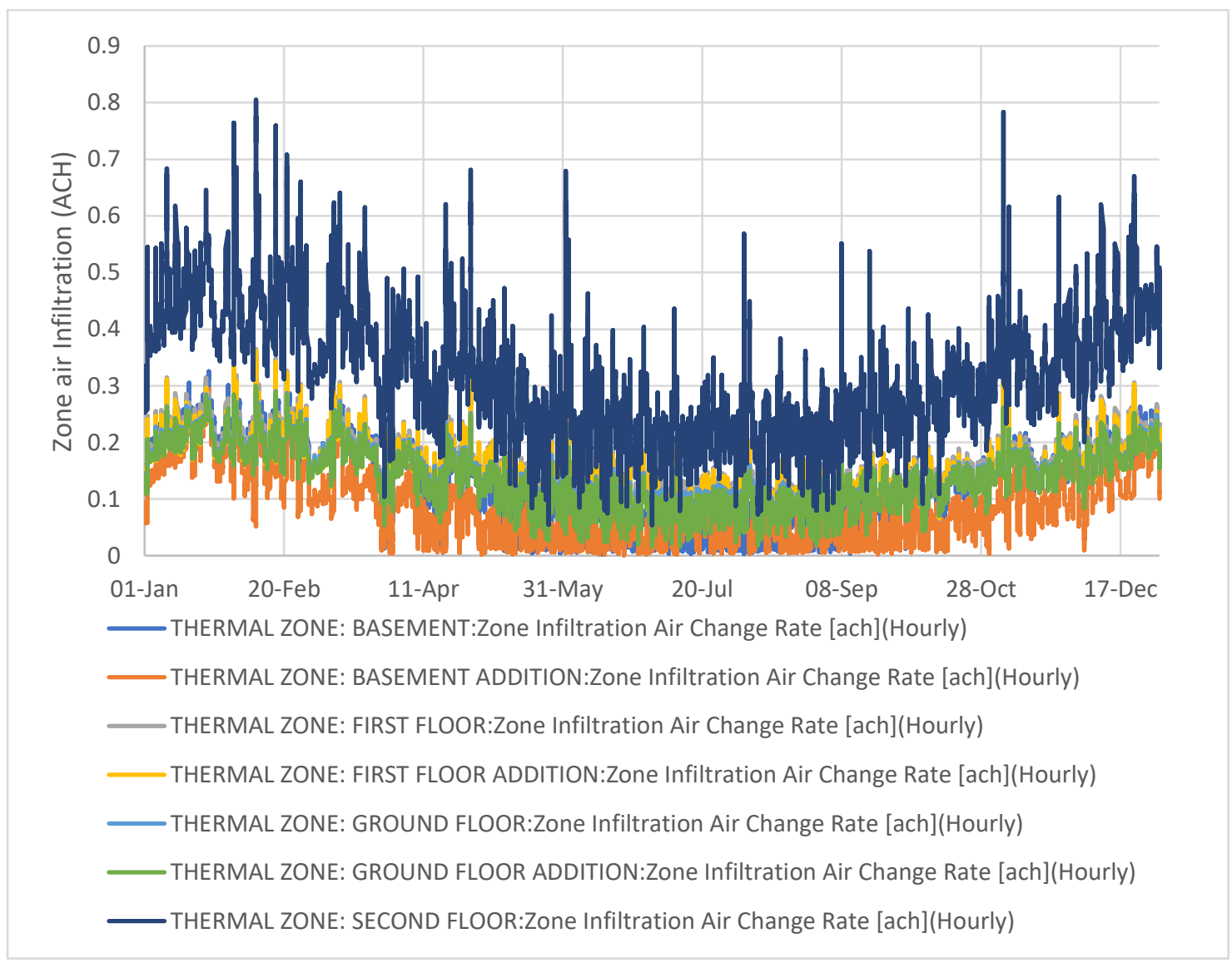

Figure 13: Zone air infiltration $(\mathrm{ACH})$ for calibrated baseline model 


\section{Calibration of Energy Model}

The model was calibrated to the measured utility bill data of recent years (2015-2017) shown in 3.2. The method of calibration was heuristic and evidence based. Important parameters to calibrate were selected through a sensitivity analysis. Thermography was conducted for qualitative understanding of the heat transfer in the building and potential areas of moisture issues. Other information obtained from the survey of the house also helped with calibration.

\subsection{Sensitivity Analysis}

\subsubsection{Methodology}

A one factor at a time sensitivity analysis was conducted on the initial energy model to identify the most sensitive parameters that may require additional measurements to improve accuracy of calibration and to inform most effective retrofit options. Uncertain parameters that were explored were the air infiltration, indoor air temperature setpoint, boiler efficiency, thermal resistance of insulation in the main house walls and addition walls, window thermal performance, stone foundation density, ground temperature, brick wall density, chimney thermal bridging, concrete floor slab density, and roof insulation thermal conductivity. Discrete values for parameters were input and simulated for each individual change. Properties of materials with different densities were obtained from ASHRAE (2017). Densities were examined for thermally massive materials because this characteristic has an impact on the material heat transfer. The sensitivity analysis process was automated by writing a python code (see GitHub link for samples of code: 
https://github.com/larissaide24/Deep-Energy-Retrofits-for-Heritage-Buildings) to change the EnergyPlus IDFs using Eppy, simulate, and store results to then be plotted.

\subsubsection{Results and Discussion}

The air leakage, heating setpoint temperature, boiler efficiency, wall thermal resistance and window properties were the most sensitive parameters. Parameters that were found to be less sensitive in the model were the ground temperature, stone foundation properties, and others so reasonable baseline values were chosen for these parameters. Figure 14 shows a summary of the sensitivity analysis results (see Appendix $\mathrm{C}$ for the full sensitivity analysis results of all discrete values simulated). The reason the temperature setpoint was considered in the sensitivity analysis was because the thermostat is close to the entrance of the house. People come and go throughout the day so the house may be heating more than it needs to due to the cold breeze hitting the thermostat frequently. To represent this in a simplified way, the setpoint was adjusted as if it was heating to a higher setpoint.

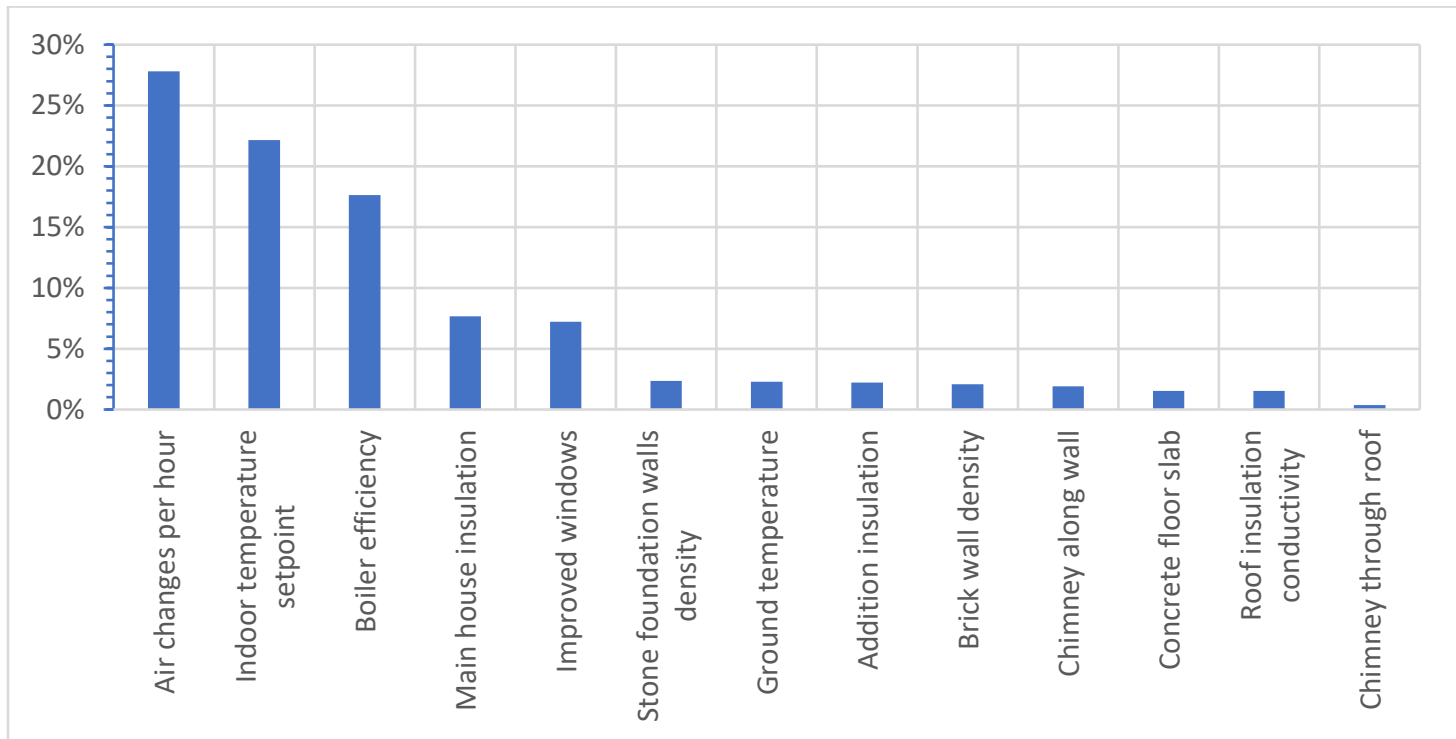

Figure 14: Summary of sensitivity analysis results for change in annual gas energy use from initial baseline $117 \mathrm{kWh} / \mathrm{m}^{2} /$ year (before calibration). Most sensitive parameters were determined to be air changes per hour of air leakage, heating setpoint, boiler efficiency, main house insulation, and improved windows. 


\subsection{Thermography}

Thermography was used to qualitatively enhance understanding of thermal bridging, air infiltration, and other issues in the house.

\subsubsection{Methodology}

Qualitative thermography helps to visualize relative differences in temperature to identify potential areas of thermal bridging, air infiltration and moisture issues. The thermographic tool used was a point and shoot focus-free FLIR E4 Wifi Imaging IR Thermometer with: $80 \times 60$ pixels resolution, accuracy of $+/-2^{\circ} \mathrm{C}(+/-2 \%)$, thermal sensitivity of $<0.15^{\circ} \mathrm{C}$ $(<150 \mathrm{mK})$, and temperature range of $-20^{\circ} \mathrm{C}$ to $250^{\circ} \mathrm{C}$. Thermography was done in the evening around $7 \mathrm{pm}$ in December to allow solar radiation to dissipate from the building envelope exterior surfaces to the environment. The greater temperature difference between interior and exterior during the evening also helps promote greater air infiltration, enhancing these patterns in the thermography. Digital photos were taken concurrently with thermographic photos (multi spectral dynamic imaging - MSX) to be able to identify objects in photos. The centre point measurements of photos are an accurate measurement of the surface temperature of objects based on the distance of measurements indicated in settings. The alignment distance used was $1.5 \mathrm{~m}$. The distance of measurements was set to $2 \mathrm{~m}$ for interior photos and $10 \mathrm{~m}$ for exterior photos. The reflected temperature was $20^{\circ} \mathrm{C}$ 
and emissivity was set to 0.9 because of the typical emissivity of building materials. The iron colour scale was used for infrared images and the temperature scale was not fixed.

\subsubsection{Results and Discussion}

The thermography revealed temperature difference patterns that suggest air infiltration occurs around the baseboards and addition back door on the ground floor (Figure 15 and Figure 16), around windows, and around the header of the second floor (Figure 17). The reason these patterns are more suggestive of air infiltration is because of their irregular shapes, whereas a moisture issue or thermal bridging would appear as a more uniform pattern. The thermography helped identify a large hole in the basement wall (Figure 18) that was previously undiscovered. Thermal bridging occurring through the chimney is evident because of the composition and the uniform higher temperature of the chimney from the exterior (Figure 17). The air infiltration from the blower door test was a good initial value for the energy model, but due to uncertainties and sensitivity of this parameter, it was adjusted for the calibration of the model. See Appendix $\mathrm{H}$ for the thermography photo key plans.
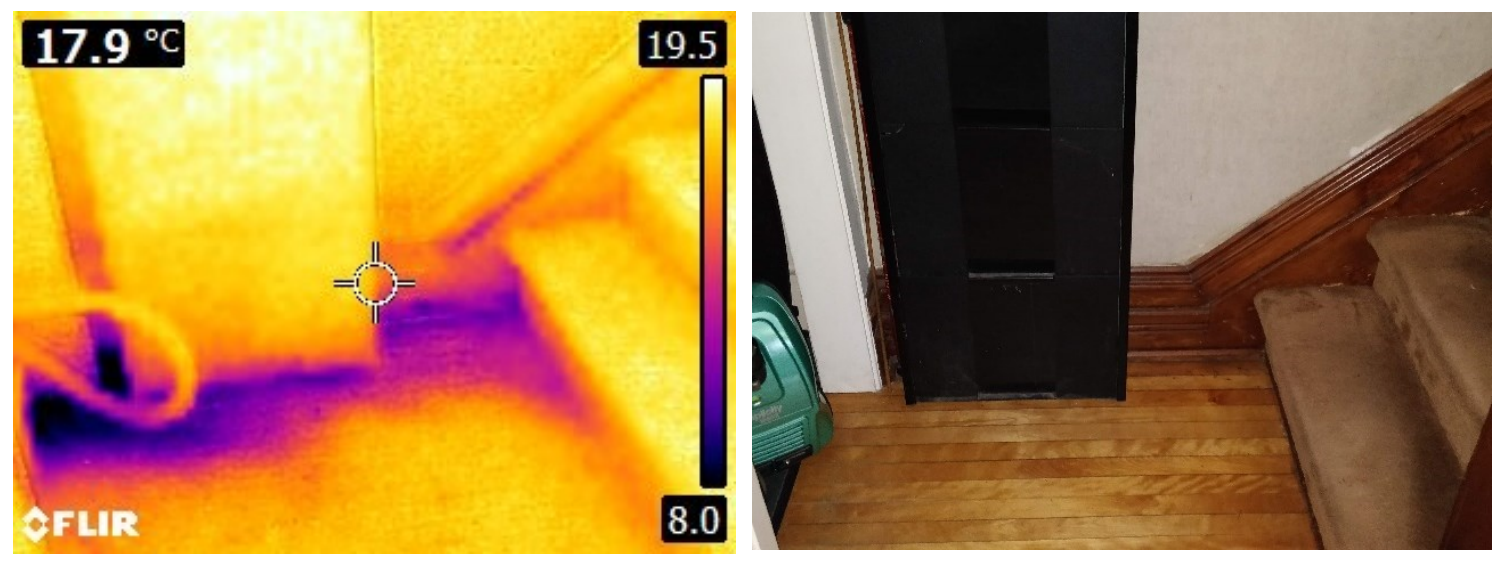

Figure 15: Thermography showing patterns suggesting air infiltration along baseboards of north wall of house at ground level and digital photo. 


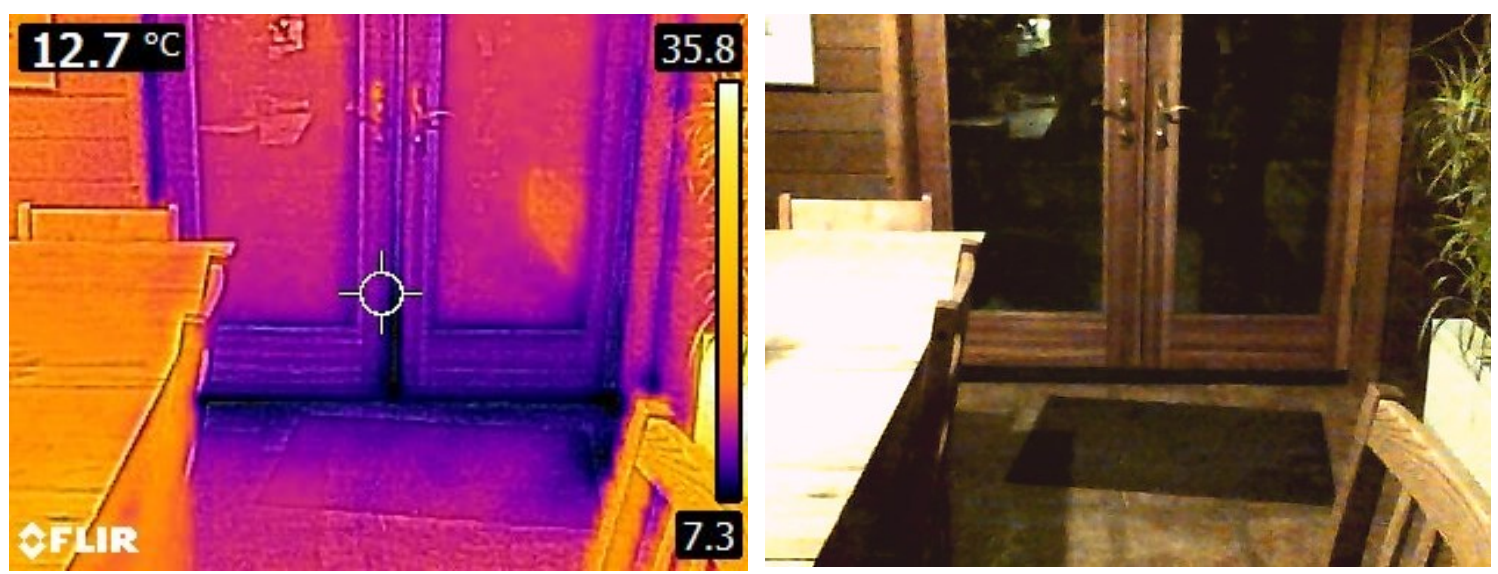

Figure 16: Patterns suggesting air infiltration along base of addition back door and digital photo.

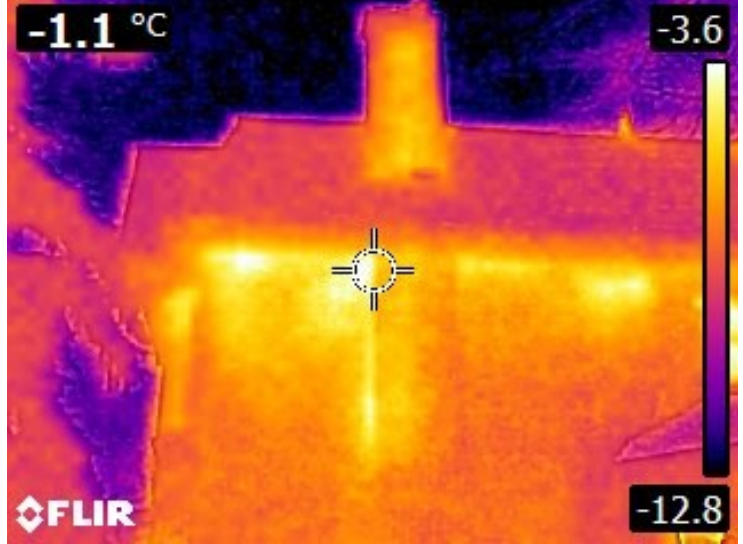

Figure 17: Heat transfer around roof (third floor) and chimney potentially indicating air infiltration at the warmest spots and likely thermal bridging through the chimney.

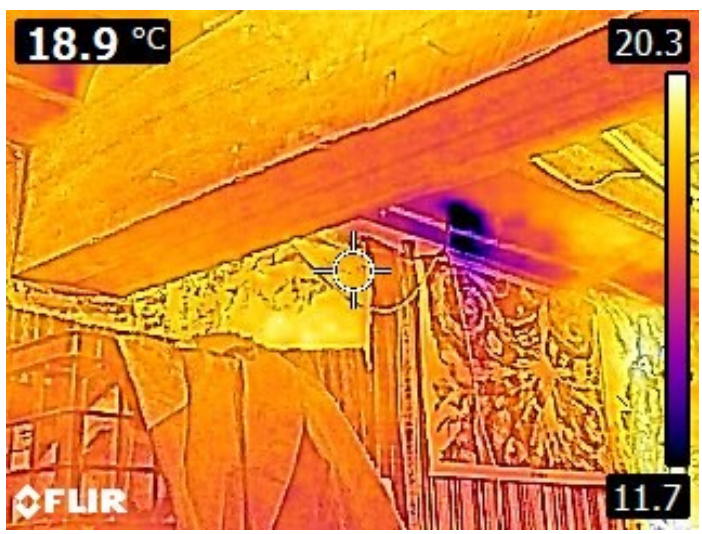

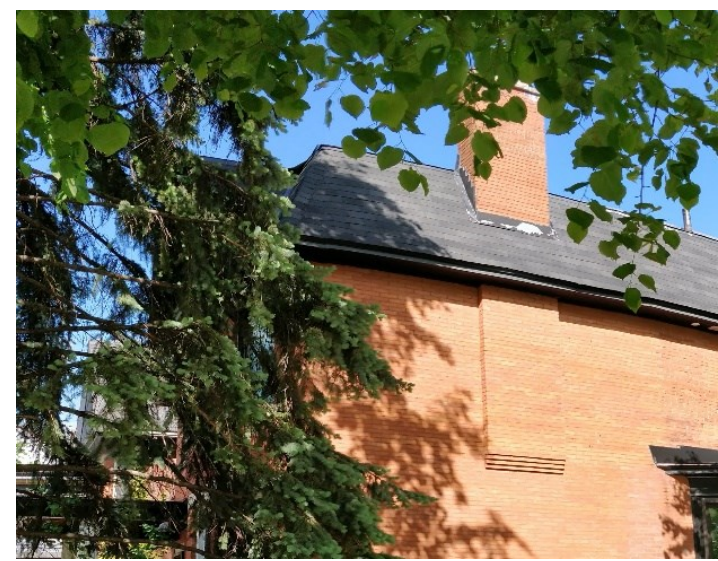

Digital photo to accompany thermography. Taken during day to see building features.

Figure 18: Hole in basement wall near addition of house discovered with thermography (digital photo on right).

Some areas of thermal bridging or potential moisture issues were found within the addition walls (Figure 19 and Figure 20). These problem areas should be investigated further to 
catch any moisture issues early on before mold starts to grow which could impact human health. To test for a moisture issue, a moisture probe can be inserted within these walls. Creating an exploratory opening to identify the materials within the wall could help identify if the pattern is from a thermal bridge. Spray foam was implemented as a recent intervention in the basement addition to reduce heat loss in this space. The issue found underneath the spray foam may be difficult to address with a minimal intervention since spray foam is difficult to remove. This demonstrates the necessity to thoroughly assess the existing condition of wall assemblies before adding additional insulation.
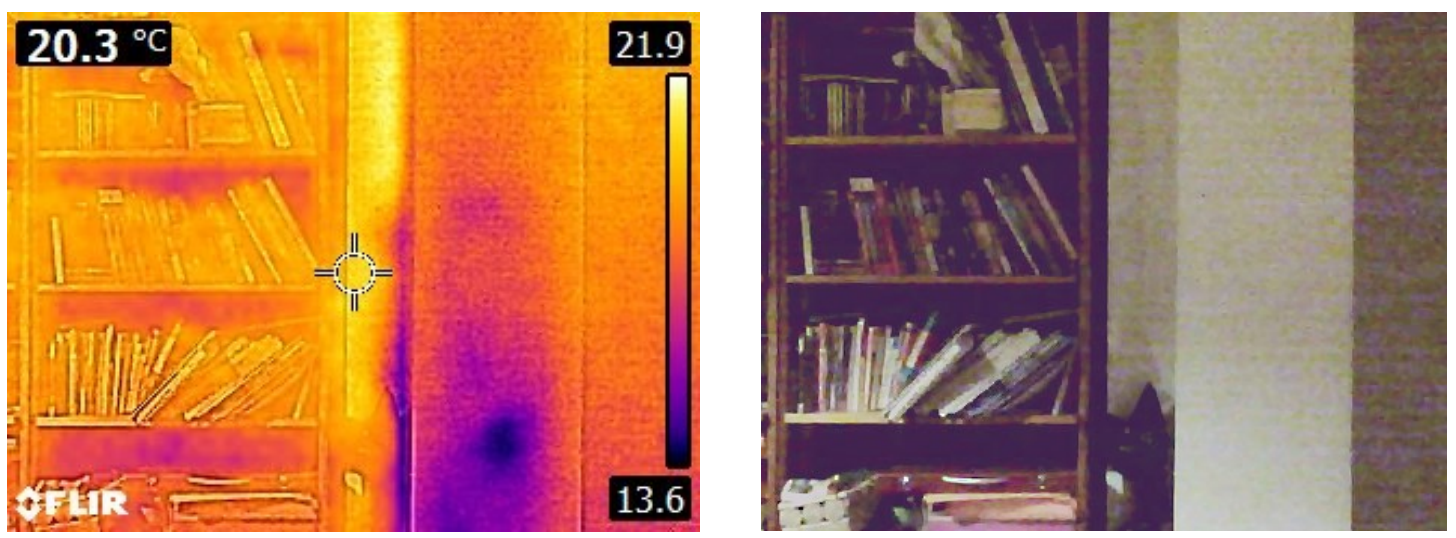

Figure 19: Wall connecting addition to main house on ground floor. Potential thermal bridging or moisture issue in wall (digital photo on right).
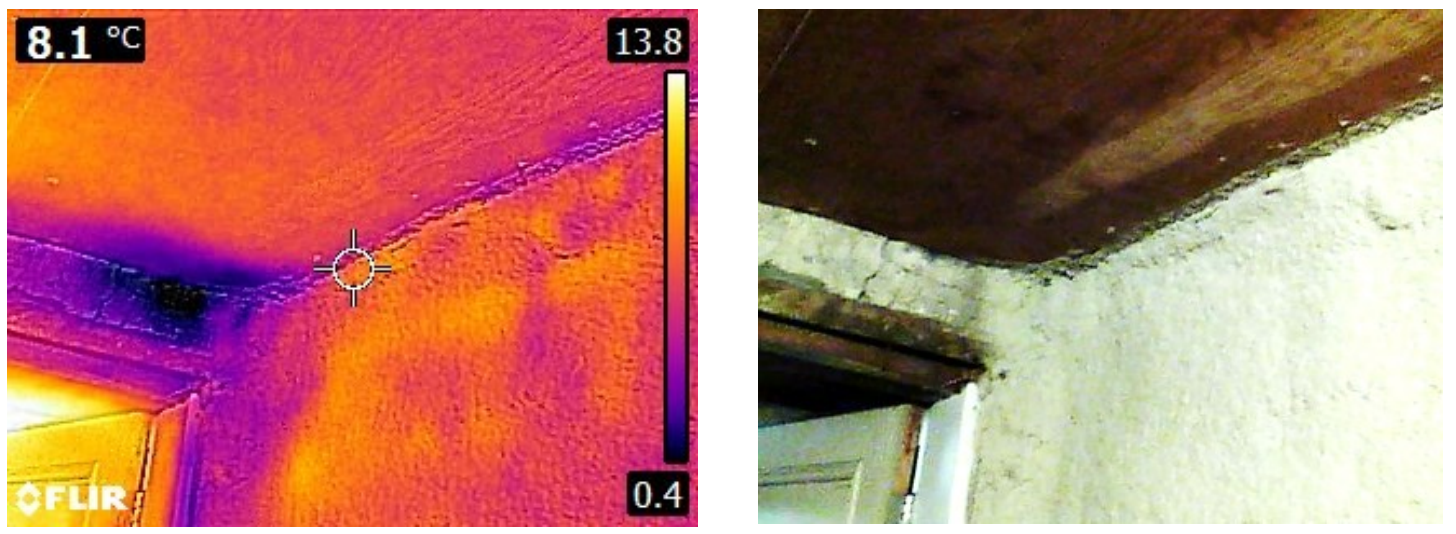

Figure 20: Potential moisture issue or thermal bridging in basement addition wall (digital photo on right). 
The historic double pane windows are performing much better than one might have expected as seen in Figure 21 because of it being able to maintain a warmer temperature. There is only some pattern of likely air infiltration occurring along the edge of the window which is operable since the surface was not wet. This can be rehabilitated to be more airtight. The figure also demonstrates the use of curtains reducing the heat loss to the exterior environment because of its warmer temperature. Thermography was useful in identifying problem areas of the house, which should be carefully examined with further testing before implementing retrofits. Conducting thermography with a blower door test would be able to identify air infiltration areas with more certainty. Inserting moisture probes in areas that are speculated to have moisture and/or thermal bridging issues based on the thermography would determine the level of moisture in these areas. Exploratory openings would determine the composition of components and help determine moisture issues and/or thermal bridges definitively.

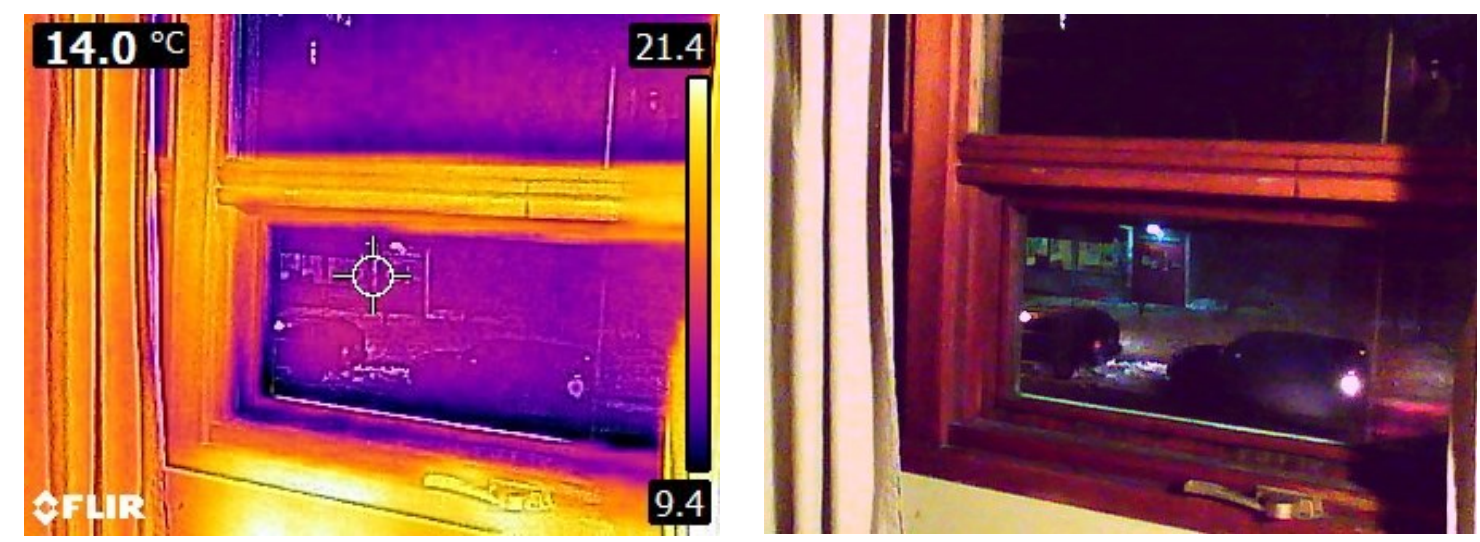

Figure 21: Historic double pane window performing quite well, only some air infiltration along opening edges of operable window. Curtains help to reduce heat loss to outdoors (digital photo on right). 


\subsection{Calibration of Energy Model}

\subsubsection{Methodology}

An actual meteorological year (AMY) file (Urbandale, 2017) was used for calibration of the model to utility bill data over a full year following the ASHRAE Guideline 14 criteria for calibration to monthly data: NMBE (normalized mean bias error) between -5\% and 5\% and CV(RMSE) (Coefficient of variation of the root mean square error) $<15 \%$ (ASHRAE, 2014). The NMBE and CV(RMSE) were calculated using the following equations (eq. 5 and 6) from ASHRAE (2014) equations shown below:

$$
\left.N M B E=\frac{1}{\bar{m}} \frac{\sum_{i=1}^{n}\left(m_{i}-s_{i}\right)}{n} \times 100 \% \quad \text { (eq. } 5\right)
$$

Where $m_{i}=$ measured energy use, $s_{i}=$ simulated energy use, $\bar{m}$ is the mean of the measured data, and $n$ is the number of measured data points. This means that a negative NMBE indicates an overall overprediction of annual energy use and a positive NMBE indicates an underprediction.

$$
C V R M S E=\frac{1}{\bar{m}} \sqrt{\frac{\sum_{i=1}^{n}\left(m_{i}-S_{i}\right)^{2}}{n}} \times 100 \%
$$

Information obtained about the house was input into the initial model to improve estimates and acceptable discrete values of sensitive uncertain parameters were simulated to complete calibration (heuristic, evidence-based calibration as described by Coakley, Raftery, and Keane (2014)). The energy model was manipulated interactively using Eppy in Python to increase speed of execution and minimize manual edits. The energy use for appliances and lighting was estimated using the average measured electricity consumption from 2015-2017 and modified until calibrated. The energy use for DHW was estimated 
based on the heating degree day (HDD) analysis for the study to determine the baseload (see Section 3.2.1).

The heat flux (Hukseflux thermal sensor HFP01-05, with $\pm 3 \%$ uncertainty and LI19 data logger) was measured for a north wall in the main part of the house and the recent addition of the house as they have different constructions. However, surface temperature measurements were not measured at the time, which led to inaccurate R-value calculations using ambient outdoor and indoor temperatures, especially with the amount of air flow occurring throughout the house. The effective R-value of the walls in the main house was estimated to be around $2.2 \mathrm{~m}^{2}-\mathrm{K} / \mathrm{W}$ based on an initial value of $3.32 \mathrm{~m}^{2}-\mathrm{K} / \mathrm{W}$ for a doublewythe brick with 38 x $140 \mathrm{~mm}$ fibreglass batt insulation from Blaszak and Richman (2012) and then adjusting for calibration. For the addition of the house, $2.6 \mathrm{~m}^{2}-\mathrm{K} / \mathrm{W}$ was the thermal resistance because of the recent insulation improvement. The schedules for occupancy, equipment use, and DHW use were refined based on detailed occupancy variation throughout the year. 
Table 3 summarizes important modelled parameters and discrete values tested for calibration of uncertain parameters. The detailed calibration methodology applied to air infiltration as an example is explained here. Air changes per hour were converted to flow coefficients using equation 1 and equation 2 (see Section 4.1). Then the flow coefficients for a range of possible $\mathrm{ACH}$ values were input into the energy model to calibrate this unknown parameter (see code on GitHub). First, the initial baseline energy model was edited using Eppy, to contain the iteration of flow coefficients. Then the new IDF was saved with a new name, simulated using an AMY weather file, the new output table was analysed to calculate NMBE and CV(RMSE) using a custom function, and the results were stored in a dictionary. The dictionary was then displayed as a table to view which iteration had the lowest NMBE and CV(RMSE) (Figure 22). Based on Figure 22, $13.5 \mathrm{ACH}$ at 50 Pa had the lowest CV(RMSE) and NMBE values so it was chosen to update the baseline model to continue further calibration of other parameters. After continuing heuristic calibration of other parameters, it was determined that the calibrated air infiltration was 14.0 ACH at $50 \mathrm{~Pa}$. 
Table 3: Model and calibration parameters

\begin{tabular}{|c|c|c|c|c|c|}
\hline Component & Sources of Uncertainty & Parameter (Units) & $\begin{array}{l}\text { Source for initial } \\
\text { model value }\end{array}$ & $\begin{array}{l}\text { Baseline model value } \\
\text { (after calibration) }\end{array}$ & $\begin{array}{l}\text { Discrete values tested for } \\
\text { calibration or modelling } \\
\text { choice }\end{array}$ \\
\hline Windows & $\begin{array}{l}\text { Not all windows are the } \\
\text { same (size, frames, time of } \\
\text { implementation), air } \\
\text { infiltration around } \\
\text { windows }\end{array}$ & $\begin{array}{l}\text { SHGC and U-value } \\
\left(\mathrm{W} / \mathrm{m}^{2}-\mathrm{K}\right)\end{array}$ & LBNL WINDOW & $\begin{array}{l}0.708 \text { SHGC } \\
2.69 \text { U-value }\left(\mathrm{W} / \mathrm{m}^{2}-\mathrm{K}\right)\end{array}$ & $\begin{array}{l}\text { Modelled clear double glazing, } \\
\text { air gap, and wooden frames in } \\
\text { LBNL WINDOW. Input } \\
\text { complex window object in } \\
\text { EnergyPlus. }\end{array}$ \\
\hline $\begin{array}{l}\text { Number of } \\
\text { occupants and } \\
\text { schedule }\end{array}$ & $\begin{array}{l}\text { Variation in occupants due } \\
\text { to bed and breakfast and } \\
\text { daycare }\end{array}$ & Number of people & $\begin{array}{l}\text { Log of occupants } \\
\text { from owner of } \\
\text { house }\end{array}$ & $\begin{array}{l}\text { Between 4-9 } \\
\text { throughout year }\end{array}$ & $\begin{array}{l}\text { Average of } 4 \text { permanent } \\
\text { occupants throughout year and } \\
\text { variations of } 4-9 \text { during the } \\
\text { day. }\end{array}$ \\
\hline DHW & $\begin{array}{l}\text { Variation in use due to } \\
\text { guests }\end{array}$ & Peak flowrate (L/hr) & $\begin{array}{l}\text { Estimate based on } \\
\text { floor area and } \\
\text { number of } \\
\text { occupants }\end{array}$ & $\begin{array}{l}16.6 \text { to } 17.5 \text { depending } \\
\text { on floor area }\end{array}$ & $\begin{array}{l}\text { Modelled using water-use } \\
\text { equipment, hot water } \\
\text { temperature } 67^{\circ} \mathrm{C} .11 .2 \text { to } 17.5 \\
\text { starting at the estimated } \\
\text { baseload and increasing by } 2 \% \\
\text { at a time. }\end{array}$ \\
\hline $\begin{array}{l}\text { Electrical } \\
\text { equipment and } \\
\text { lighting }\end{array}$ & $\begin{array}{l}\text { Scheduling of several } \\
\text { different appliances, } \\
\text { portion used for lighting } \\
\text { and portion used for } \\
\text { appliances. }\end{array}$ & $\begin{array}{l}\text { Watts per zone floor } \\
\text { area }\left(\mathrm{W} / \mathrm{m}^{2}\right)\end{array}$ & $\begin{array}{l}\text { Average of } \\
\text { measured } \\
\text { electricity energy } \\
\text { use }\end{array}$ & $\begin{array}{l}6.21 \text { for equipment and } \\
2.4 \text { to } 2.6 \text { for lighting } \\
\text { depending on the zone }\end{array}$ & $\begin{array}{l}\text { Modelled using general } \\
\text { electrical equipment object. } \\
\text { More detailed modelling not } \\
\text { required for monthly } \\
\text { resolution. }\end{array}$ \\
\hline $\begin{array}{l}\text { Ground } \\
\text { temperature }\end{array}$ & $\begin{array}{l}\text { Ground temperature is not } \\
\text { measured in weather file } \\
\text { and can vary over year }\end{array}$ & $\begin{array}{l}\text { Average temperature } \\
\text { of ground at } 6 \mathrm{~m} \\
\text { depth }\left({ }^{\circ} \mathrm{C}\right)\end{array}$ & $\begin{array}{l}\text { Default in } \\
\text { EnergyPlus } \\
\left(18^{\circ} \mathrm{C}\right)\end{array}$ & 5.0 & $5.0,6.8$ \\
\hline Roof construction & $\begin{array}{l}\text { Amount and condition of } \\
\text { insulation }\end{array}$ & $\begin{array}{l}\text { Effective R-value } \\
\left(\mathrm{K}-\mathrm{m}^{2} / \mathrm{W}\right)\end{array}$ & $\begin{array}{l}\text { OpenStudio } \\
\text { component library }\end{array}$ & 9.8 & $\begin{array}{l}\text { Recently insulated with blow- } \\
\text { in cellulose. Low sensitivity } \\
\text { parameter. }\end{array}$ \\
\hline $\begin{array}{l}\text { Basement wall } \\
\text { insulation }\end{array}$ & $\begin{array}{l}\text { Condition of insulation } \\
\text { and R-value }\end{array}$ & $\mathrm{R}$-value $\left(\mathrm{K}-\mathrm{m}^{2} / \mathrm{W}\right)$ & $\begin{array}{l}\text { OpenStudio } \\
\text { component library }\end{array}$ & 1.9 & 1.5 to 5 ( 0.1 increments $)$ \\
\hline Basement floor & Concrete slab properties & $\mathrm{R}$-value $\left(\mathrm{K}-\mathrm{m}^{2} / \mathrm{W}\right)$ & $\begin{array}{l}\text { OpenStudio } \\
\text { component library }\end{array}$ & 0.3 & $\begin{array}{l}\text { Used 8-inch heavyweight } \\
\text { concrete as approximation. }\end{array}$ \\
\hline
\end{tabular}




\begin{tabular}{|c|c|c|c|c|c|}
\hline Component & Sources of Uncertainty & Parameter (Units) & $\begin{array}{l}\text { Source for initial } \\
\text { model value }\end{array}$ & $\begin{array}{l}\text { Baseline model } \\
\text { value (after } \\
\text { calibration) }\end{array}$ & $\begin{array}{l}\text { Discrete values tested for } \\
\text { calibration or modelling } \\
\text { choice }\end{array}$ \\
\hline $\begin{array}{l}\text { Basement addition } \\
\text { walls }\end{array}$ & $\begin{array}{l}\text { Amount and condition of } \\
\text { insulation }\end{array}$ & $\begin{array}{l}\text { Effective R-value } \\
\left(\mathrm{K}-\mathrm{m}^{2} / \mathrm{W}\right)\end{array}$ & $\begin{array}{l}\text { OpenStudio } \\
\text { component library }\end{array}$ & 2.6 & 2 to 5 (0.1 increments) \\
\hline Main house walls & $\begin{array}{l}\text { Amount and condition of } \\
\text { insulation }\end{array}$ & $\begin{array}{l}\text { Effective R-value } \\
\left(\mathrm{K}-\mathrm{m}^{2} / \mathrm{W}\right)\end{array}$ & $\begin{array}{l}\text { OpenStudio } \\
\text { component library; } \\
\text { Blaszak, } 2013\end{array}$ & 2.2 & $\begin{array}{l}\text { Estimated from Blaszak and } \\
\text { Richman (2012). }\end{array}$ \\
\hline $\begin{array}{l}\text { Addition of house } \\
\text { walls }\end{array}$ & $\begin{array}{l}\text { Amount and condition of } \\
\text { insulation }\end{array}$ & $\begin{array}{l}\text { Effective R-value } \\
\left(\mathrm{K}-\mathrm{m}^{2} / \mathrm{W}\right)\end{array}$ & $\begin{array}{l}\text { OpenStudio } \\
\text { component library; } \\
\text { Blaszak, } 2013\end{array}$ & 2.6 & $\begin{array}{l}\text { Estimated from previous house } \\
\text { retrofit report. Additional } \\
\text { insulation installed recently. }\end{array}$ \\
\hline Thermal bridging & Location and magnitude & - & Thermography & $\begin{array}{l}\text { Geometry and } \\
\text { construction for } \\
\text { thermal bridging } \\
\text { along chimney }\end{array}$ & $\begin{array}{l}\text { Created geometry for chimney } \\
\text { and used brick construction } \\
\text { with air gap. }\end{array}$ \\
\hline $\begin{array}{l}\text { Heating system } \\
\text { on/off schedule }\end{array}$ & $\begin{array}{l}\text { Whether HVAC system is } \\
\text { heating for a setpoint of } \\
21^{\circ} \mathrm{C}\end{array}$ & $\begin{array}{l}\text { Temperature setpoint } \\
\left({ }^{\circ} \mathrm{C}\right)\end{array}$ & $\begin{array}{l}\text { Keller-Herzog, } \\
2018\end{array}$ & 23.0 & $\begin{array}{l}21 \text { to } 25(0.5 \text { increments }) \\
23.0 \text { to } 23.6(0.1 \text { increments })^{*}\end{array}$ \\
\hline Air leakage & $\begin{array}{l}\text { Accuracy of previously } \\
\text { conducted blower door } \\
\text { tests }\end{array}$ & $\begin{array}{l}\text { Air-changes-per- } \\
\text { hour at } 50 \mathrm{~Pa}\left(\mathrm{~h}^{-1}\right)\end{array}$ & Blower door test & 14 & $\begin{array}{l}\text { 7-14.0 ACH (0.5 increments }) \text { at } \\
50 \mathrm{~Pa}\end{array}$ \\
\hline HVAC System & $\begin{array}{l}\text { Existing gas boiler } \\
\text { efficiency }\end{array}$ & $\begin{array}{l}\text { Efficiency of system } \\
\text { (fraction) }\end{array}$ & $\begin{array}{l}\text { Documentation of } \\
\text { existing system in } \\
\text { house }\end{array}$ & $\begin{array}{l}\text { Gas boiler with } 0.7 \\
\text { efficiency }\end{array}$ & 0.6 to $0.8(0.5 \text { increments })^{* *}$ \\
\hline
\end{tabular}

Notes for Table 3:

* The thermostat temperature was a sensitive parameter. It is located close to the entrance of the house which has cold air flowing in frequently due to guests coming in and out of the house. The house is likely heating more than it needs to.

** The boiler was installed in 2013 . 


\begin{tabular}{|c|c|c|c|c|c|c|}
\hline & 11.2 & 11.399999999999999 & 11.599999999999998 & 11.799999999999997 & 11.999999999999996 & 12.5 \\
\hline CVRMSE & 37.1877 & 36.7898 & 36.3557 & 35.9602 & 35.5423 & 34.5078 \\
\hline $\begin{array}{r}\text { Monthly } \\
\text { Elec }\end{array}$ & $\begin{array}{r}{[1099.69} \\
992.8900000000001 \\
1097.54,1045.31, \ldots\end{array}$ & $\begin{array}{r}{[1100.16,993.32} \\
1098.02,1045.76 \\
1067.23,1 \ldots\end{array}$ & $\begin{array}{r}{[1100.66} \\
993.7600000000001 \\
1098.51,1046.17, \ldots\end{array}$ & $\begin{array}{r}{[1101.13,994.19} \\
1098.99 \\
1046.6100000000001, \ldots\end{array}$ & $\begin{array}{r}{[1101.61} \\
994.6300000000001 \\
1099.48,1047.06, \ldots\end{array}$ & $\begin{array}{r}{[1102.83} \\
995.73 \\
1100.7 \\
1048.19 \\
1069.49 \\
10\end{array}$ \\
\hline $\begin{array}{r}\text { Monthly } \\
\text { Gas }\end{array}$ & $\begin{array}{r}{[5048.81,4296.14} \\
4127.62,1885.83 \\
1436.12, \ldots\end{array}$ & $\begin{array}{r}{[5069.66,4315.92} \\
4150.01,1894.6 \\
1441.4,59 \ldots\end{array}$ & $\begin{array}{r}{[5097.04,4336.42} \\
4173.12,1903.46 \\
1446.65, \ldots\end{array}$ & $\begin{array}{r}{[5117.87,4356.21} \\
4195.48,1912.23 \\
1451.9,5 \ldots\end{array}$ & $\begin{array}{r}{[5142.26,4376.56} \\
4218.469999999999 \\
1921.110 \ldots\end{array}$ & $\begin{array}{r}{[5202.81,} \\
4427.21, \\
4275.66, \\
1943.25, \\
1470.4, \\
6 \ldots\end{array}$ \\
\hline NMBE & 27.0578 & 26.7258 & 26.3745 & 26.0429 & 25.6976 & 24.8384 \\
\hline
\end{tabular}

\begin{tabular}{|c|c|c|}
\hline & 13.0 & 13.5 \\
\hline CVRMSE & 33.4803 & 32.4695 \\
\hline $\begin{array}{r}\text { Monthly } \\
\text { Elec }\end{array}$ & $\begin{array}{r}{[1104.04,996.84} \\
1101.93,1049.27 \\
1070.54,1 \ldots\end{array}$ & $\begin{array}{r}{[1105.25} \\
997.9200000000001 \\
1103.15,1050.35, \ldots\end{array}$ \\
\hline $\begin{array}{r}\text { Monthly } \\
\text { Gas }\end{array}$ & $\begin{array}{r}{[5263.42,4477.89} \\
4332.9 \\
1965.3899999999999, \ldots\end{array}$ & $\begin{array}{r}{[5323.5,4528.14} \\
4389.6900000000005, \\
1987.38, \ldots\end{array}$ \\
\hline NMBE & 23.9795 & 23.1273 \\
\hline
\end{tabular}

Figure 22: Table displaying NMBE and CV(RMSE) values for different $A C H$ values of air infiltration at $50 \mathrm{~Pa}$.

\subsubsection{Results and Discussion}

The calibration achieved for the gas use had a NMBE of $-2.1 \%$ and CV(RMSE) of $14.9 \%$ (Figure 23). The calibration achieved for electricity had a NMBE of $-3.6 \%$ and CV(RMSE) of $14.4 \%$ (Figure 24). The annual gas and electricity consumption of this baseline model were $121 \mathrm{kWh} / \mathrm{m}^{2}$ (includes $24.4 \mathrm{kWh} / \mathrm{m}^{2}$ for DHW heating) and $39 \mathrm{kWh} / \mathrm{m}^{2}$.

After calibration, the model should be validated with a separate year of measured utility bill data (if possible) to ensure that the model still meets calibration guidelines and to check for overfitting. Validation with another year of utility bill data was not possible for this case study because the previous and following years involved additional changes to the building. The washing machine was replaced with a super high efficiency one, a new 
door was ordered, and a few new windows were installed in 2018 (Keller-Herzog, 2018a). In 2014, 2015, and 2016, a pump was replaced, the hot water heater was replaced with a tankless hot water heater, and a condensing dryer was purchased to replace the low efficiency dryer (Keller-Herzog, 2018a). Other parameters that can be used to evaluate the quality of calibration are Goodness of Fit (GoF, lower number is better) and the coefficient of determination ( $\mathrm{R}^{2}$, closer to 1 is best) as explained by Ruiz \& Bandera (2017). These values were calculated to be 10.67 and 0.35 for the final calibration. If time permitted, the calibration would be improved with further measurements such as precise heat flux measurements with surface temperature measurements indoors and outdoors, submetering the different hydronic heating loops, submetering electrical lighting, and recording occupancy in detail throughout the day to improve these other important indicators.

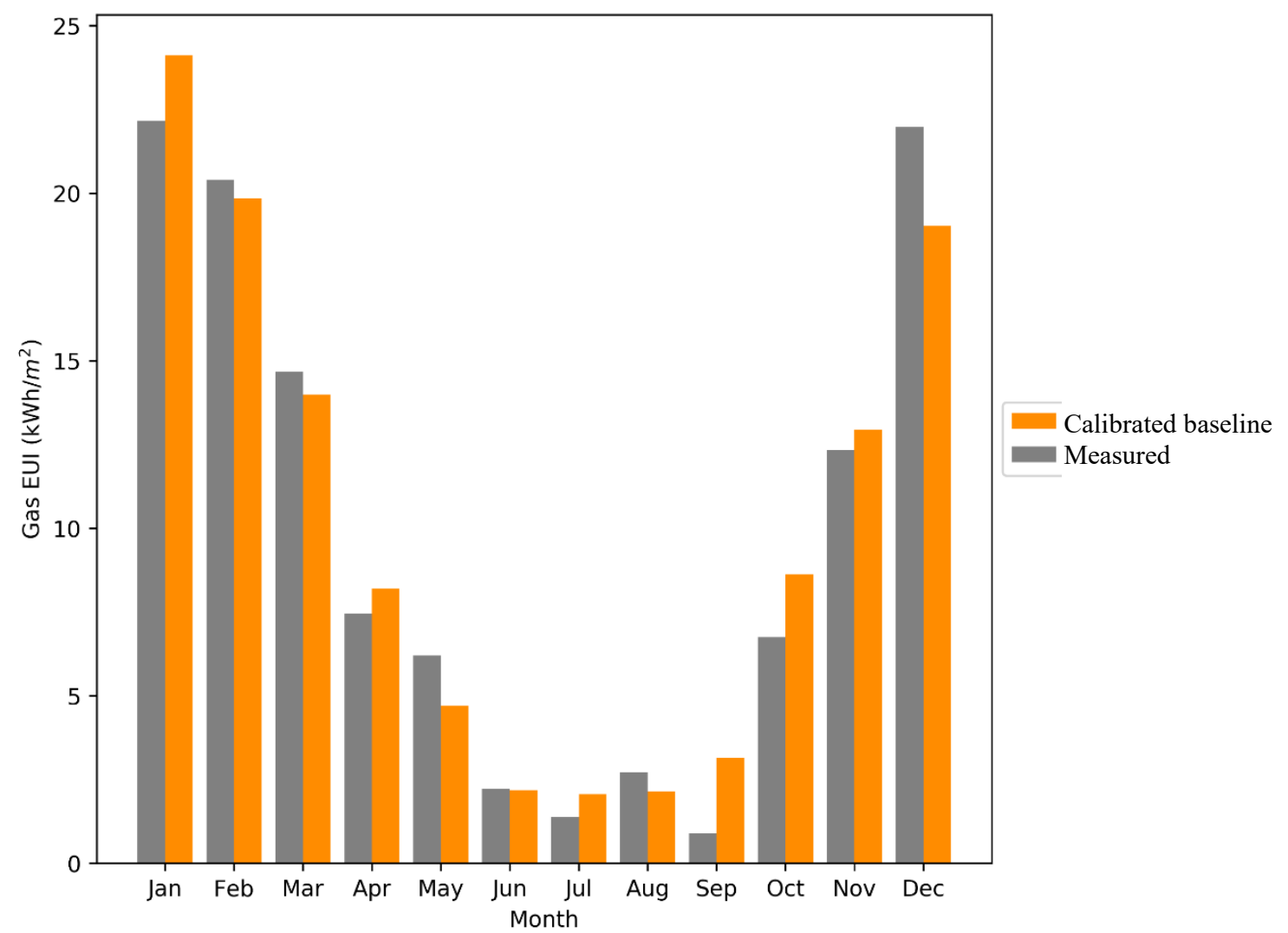

Figure 23: Measured gas and calibration results for gas energy use. $N M B E=-2.1 \%$ and $C V(R M S E)=14.9 \%$. 


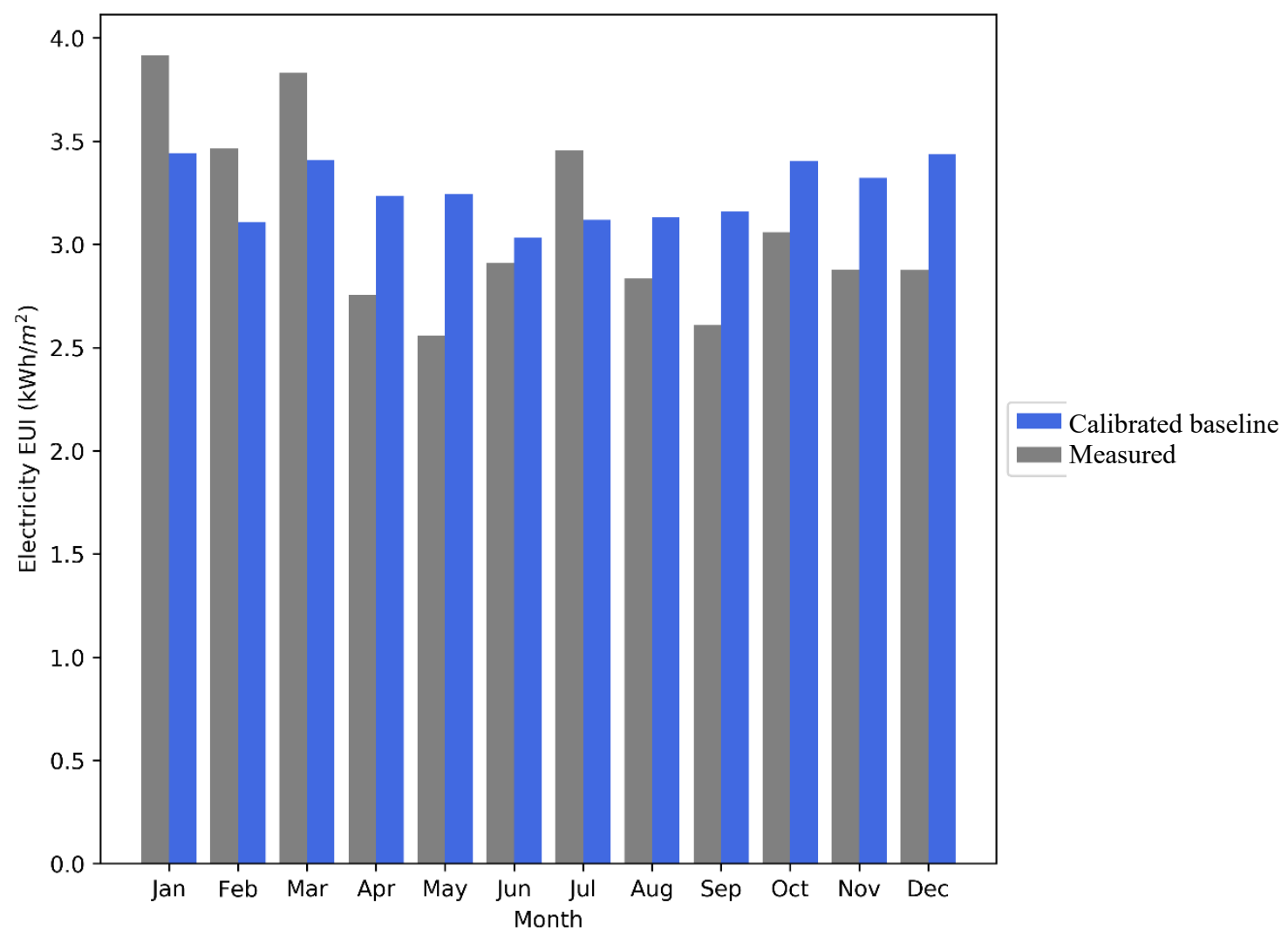

Figure 24: Measured electricity and calibration results for electricity energy use. NMBE $=-3.6 \%$ and $C V(R M S E)=14.4 \%$.

\subsection{Conclusion}

The one factor at a time sensitivity analysis was useful to inform the calibration of the energy model based on most sensitive parameters. Thermography was useful to have a holistic understanding of the behaviour of the house and identify problem areas of potential thermal bridging, air infiltration, and moisture issues. The calibration was conducted heuristically based on evidence known about the house to achieve $-2.1 \%$ and $14.9 \% \mathrm{NMBE}$ and CV(RMSE) for gas energy use and $-3.6 \%$ and $14.4 \%$ for NMBE and CV(RMSE) for electricity energy use. For future calibrations, it is recommended to collect data about the house such as precise heat flux measurements coupled with surface temperature measurements of the walls indoor and outdoors and correct environmental conditions 
(greater than $10^{\circ} \mathrm{C}$ temperature difference between indoors and outdoors), submetering the different hydronic heating loops, submetering electrical lighting, and recording occupancy in detail throughout the day. It is also recommended to use multiple indicators (NMBE, $\mathrm{CV}(\mathrm{RMSE}), \mathrm{GoF}, \mathrm{R}^{2}$ ) to achieve a higher accuracy in the calibration and representation of energy use profile in reality.

\section{Balancing Between Heritage Conservation and Energy Reductions \\ 6.1 Decision framework for Balancing Heritage Conservation and Sustainability}

Once the model is fully calibrated and validated, viable retrofit options should be selected based on sensitive parameters and other risk factors in terms of conserving heritage values. For example, if the lighting power is sensitive and can be changed without impacting the heritage character, a lighting retrofit that maximizes daylight should be selected for the analysis. This may also favour inherent energy efficient features in an HB and help conserve the heritage characteristics. A library of retrofit options, created by the author, is presented in Figure 25 to help identify the parameters for analysis. Important risk analyses to consider include heritage impact, hygrothermal analysis to assess change in moisture behaviour (e.g. when adding insulation), cost analyses, and occupant health/comfort. 


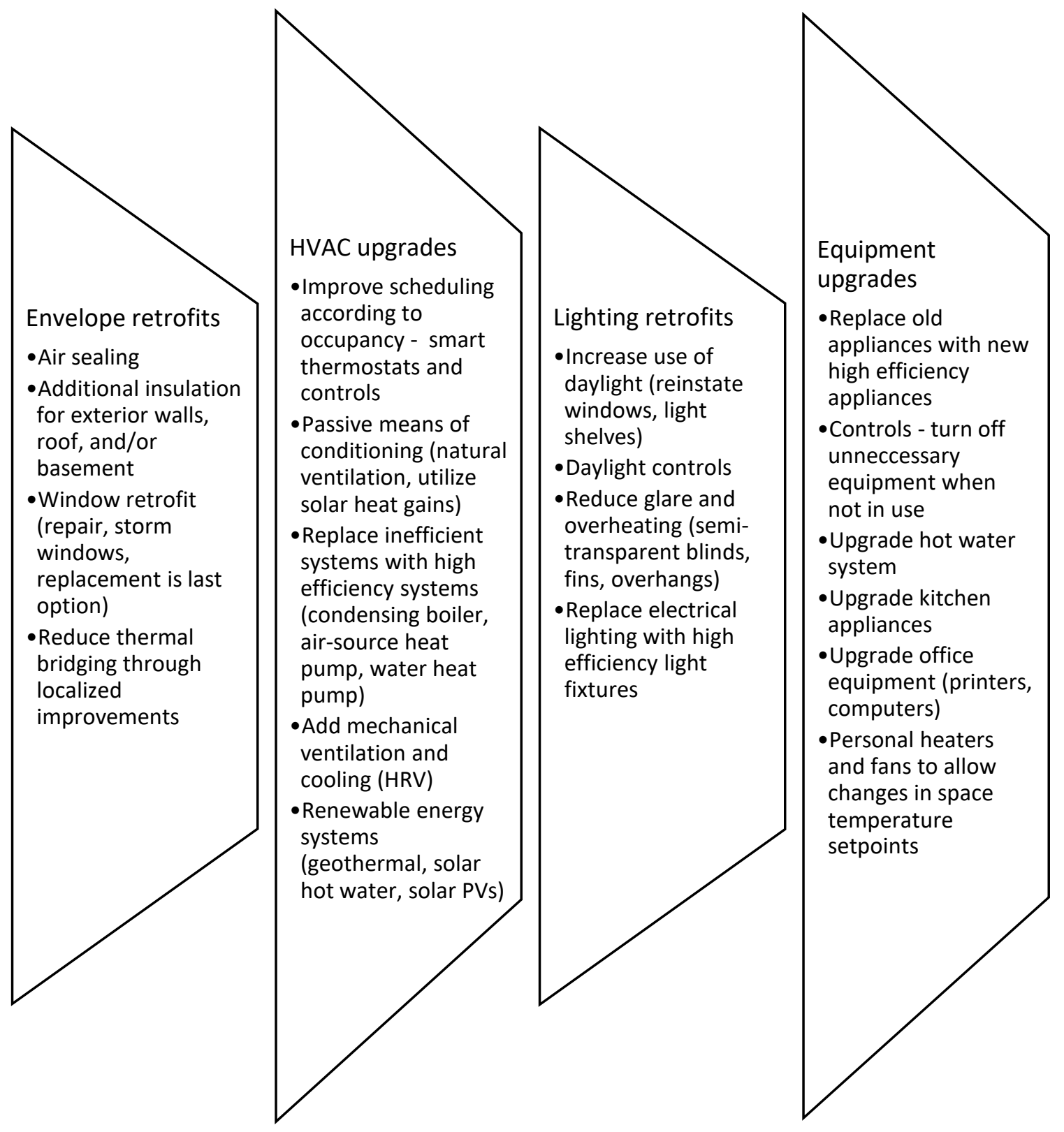

Figure 25: Library of retrofit options by retrofit type

The balance between heritage and environmental sustainability can be achieved by comparing the energy savings and risk to heritage values, while also considering other aspects of sustainability (e.g. occupant comfort). The following metrics and criteria may be used in the analysis of balancing heritage and sustainability. 


\section{Environmental Sustainability Metrics and Criteria}

- Overall wellness of occupants (IEQ, $\mathrm{CO}_{2}$, daylight)

- GHG emissions including embodied carbon of new materials vs existing materials

- Reduction in total EUI (energy use intensity) by $50 \%$ or more to achieve a deep energy retrofit

- Climate change resilience - indoor air temperature in free floating conditions, change in energy use and renewable energy

\section{Heritage Metrics and Criteria}

- Minimal intervention (refer to Parks Canada, (2010))

- Respectful of heritage values

- Reversibility (i.e. can not solely use spray foam on entire wall, but may be able to do this on new materials which do not have heritage values)

- Adaptability to current and future needs

- Proven technology

Knowing the sustainability and heritage criteria above, the balancing of these two broad objectives becomes clearer, but which has a higher priority in the comparison between the two? Does heritage have higher priority over environmental sustainability, or the other way around? Prioritization will depend on the significance of the element impacted by each retrofit option. That is why the heritage impact assessment is crucial in utilizing the decision framework to balance heritage and energy reductions. The potential heritage impact assessment should be carried out following Section 5 of ICOMOS (2011) (see 
Appendix I). To summarize this evaluation method, a more significant element of a place and a greater severity or scale of impact results in a greater overall potential impact.

Many retrofit options will have low heritage impact and implementing more changes to more HBs would help to mitigate the severity of climate change and conserve the heritage values in a new manner. This does not mean drastically changing the existing building to construct a net zero energy/carbon building. With many major changes, there is a risk of jeopardizing the authenticity and integrity of the heritage values of the building. It is still best to utilize the existing materials of the building and prioritize minimal intervention. Minimal intervention can be executed in different ways. It may mean repairing the existing historic windows so that they are airtight and adding a storm window because this is the minimal intervention required to improve the thermal performance of the windows.

To utilize the decision framework, first we look at reducing the current operational energy use intensity by a total of $50 \%$. Any measure that contributes to EUI reduction individually should be considered. A measure is determined to be viable based on reduction in EUI, occupant comfort, and respecting heritage values using the guidance provided by the decision framework shown in Figure 26. Then it can be evaluated based on climate change resilience and other project objectives not included in this study. 
Decision Framework for Selecting Viable Energy Retrofit Measures-Evaluate Individual Measures

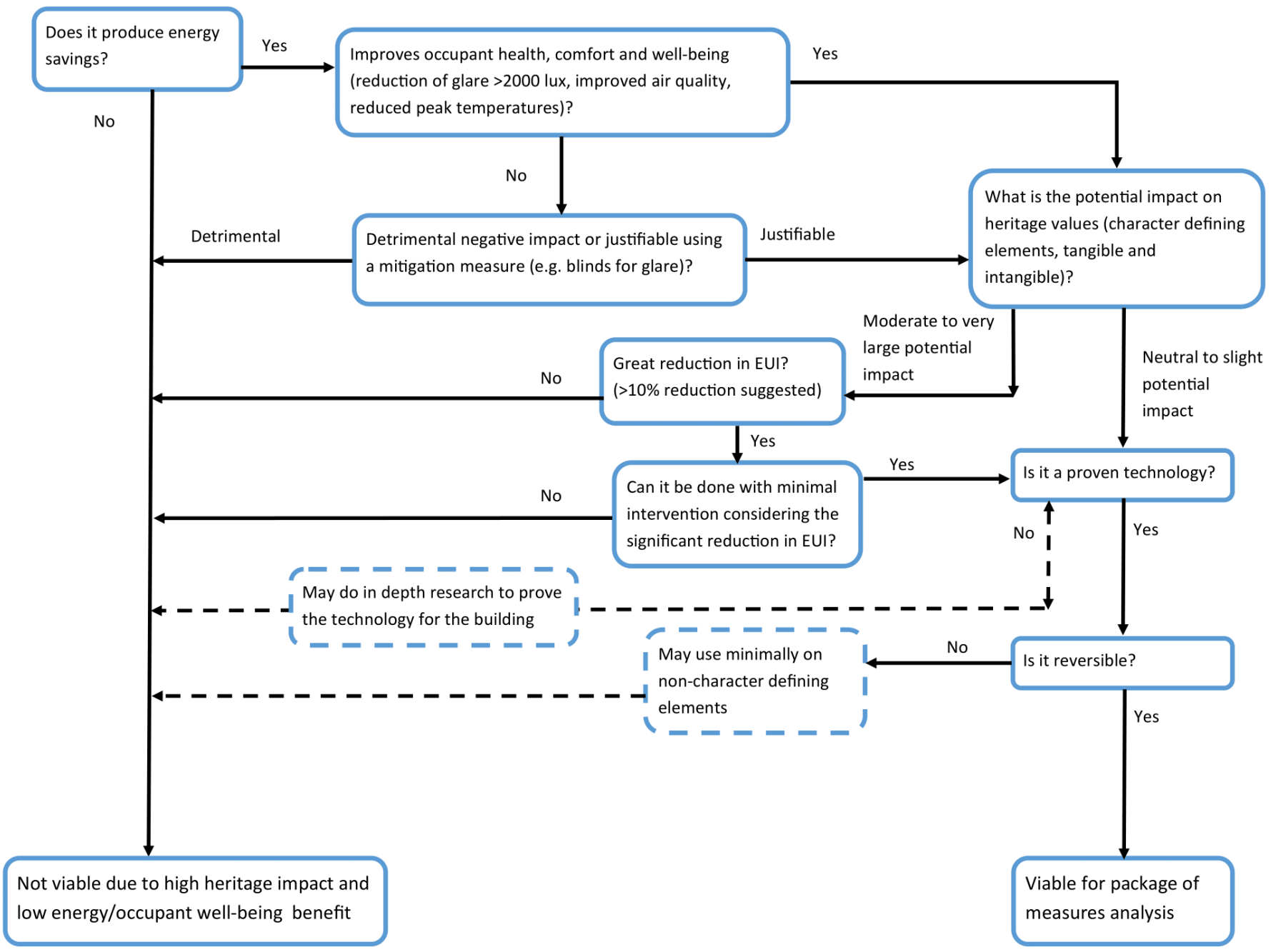

Figure 26: Decision framework for balancing energy reductions and heritage conservation, while also considering occupant comfort. If not proven technology, perform in-depth research to understand the risk before considering the technology. 


\subsection{Retrofit Options}

First retrofit measures for the building envelope were considered because this would impact the peak load for the HVAC system. Adding insulation was considered for the interior of the exterior walls because of the character defining exterior brick cladding. To determine appropriate levels of insulation, the existing wall assembly was examined and only a thickness of insulation that would fit in the existing stud cavity or on the interior of the studs before new gypsum board was considered (see Figure 27 for wall details). It was important to ensure no increase or minimal increase in wall assembly thickness. PIR (polyisocyanurate) rigid insulation board was considered as the insulation material for its high thermal resistance of $0.022 \mathrm{~W} / \mathrm{m}-\mathrm{K}$ and potential to easily remove this retrofit (whereas with spray foam, it is much more difficult to remove if necessary). Wall rehabilitation scenario 1 results in a $2.5 \mathrm{~mm}$ increase and $0.8 \mathrm{~m}^{2}-\mathrm{K} / \mathrm{W}$ improvement in thermal resistance, scenario 2 results in a $15.5 \mathrm{~mm}$ increase and $1.9 \mathrm{~m}^{2}-\mathrm{K} / \mathrm{W}$ improvement, and scenario 3 results in a $40.5 \mathrm{~mm}$ increase and $2.9 \mathrm{~m}^{2}-\mathrm{K} / \mathrm{W}$ improvement. Since there is already some insulation on the basement walls but not on the floor, insulation for the basement floor was considered (see Appendix D for table of insulation retrofit scenarios). The roof was recently insulated with blow-in cellulose, so this was not explored as an option.

Window retrofits were considered to reduce infiltration and improve thermal resistance, such as adding an interior storm window to effectively make the assembly a triple-pane clear glass window or a new triple glazed window with low-E coating and argon gas. If it is possible to modify the existing window to have low-E coating and argon gas filling, this would be a good option to conserve the authenticity of this value of the house 
(Historic England, 2016; Parks Canada, 2010). Air sealing the leakage pathways in the house was also explored as an option.

On the mechanical side, an air-source heat pump was analysed as an option because the house does not have mechanical ventilation for cooling during the summer, and the owner noted that guests are feeling uncomfortable as temperatures increase each summer. This would not have a negative impact on the character of the house if the historic radiators are conserved. The air-source heat pump is assumed to provide supplemental heating to the house to reduce gas energy use of the boiler above outdoor temperatures of $-5^{\circ} \mathrm{C}$ (NRCan, 2004). Daylight sensors and controls were modelled to turn off electrical lighting when daylight lux at the working plane is greater than 500 lux. This level of illuminance from daylight provides ample lighting to complete regular tasks and will save energy from unnecessary electrical lighting. Additional PV panels were explored as a retrofit option to increase the on-site electricity generation from renewable sources (see Sections 7 and 8, and Appendix E). Appliance upgrades of connecting sensors and controls to the plugs of appliances was also considered as a low heritage impact measure. Timers and timer plug strips or load-sensors and plug strips may be used to turn appliances off after specific times or below a specific load threshold which indicates the appliance is not in use. Older appliances may also be replaced with new efficient ones at the end of their lives. These appliance upgrades can save between 19\%-40\% based on Mercier \& Moorefield (2011). See Table 4 for a summary of the retrofits explored, heritage significance of the element impacted by retrofit, and the potential overall heritage impact. 


\section{Existing Wall Detail: $2.2 \mathrm{~m}^{2}-\mathrm{K} / \mathrm{W}$}

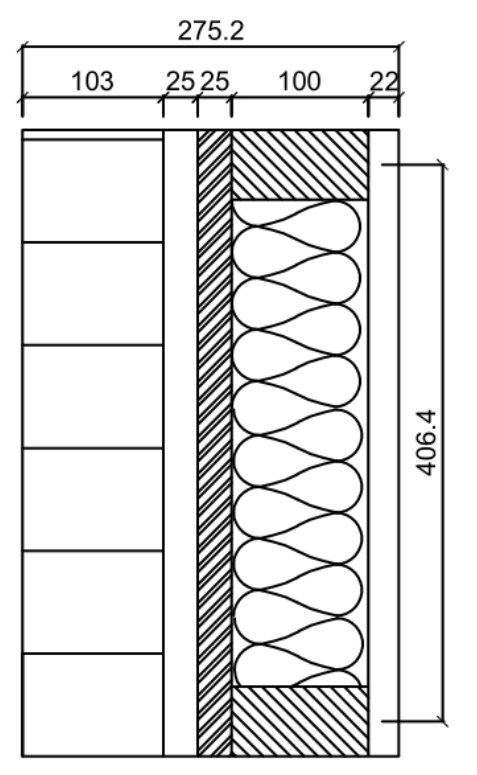

(1) (2)(3) (4) (5)
(1) Brick

(2) Air cavity with ties

(3) Wood sheathing

(4) Wood framing with

(5) Lath and plaster

Units are in $\mathrm{mm}$
Rehabilitation 1 Detail: $3.0 \mathrm{~m}^{2}-\mathrm{K} / \mathrm{W}$

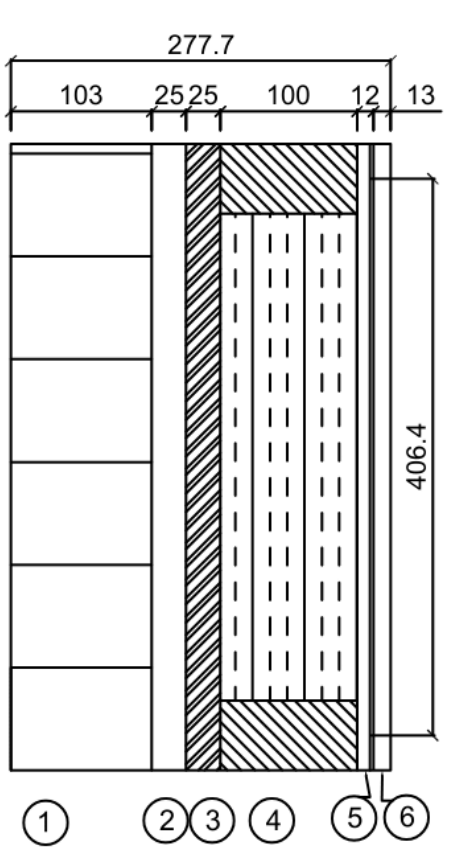

Rehabilitation 2 Detail: $4.1 \mathrm{~m}^{2}-\mathrm{K} / \mathrm{W}$

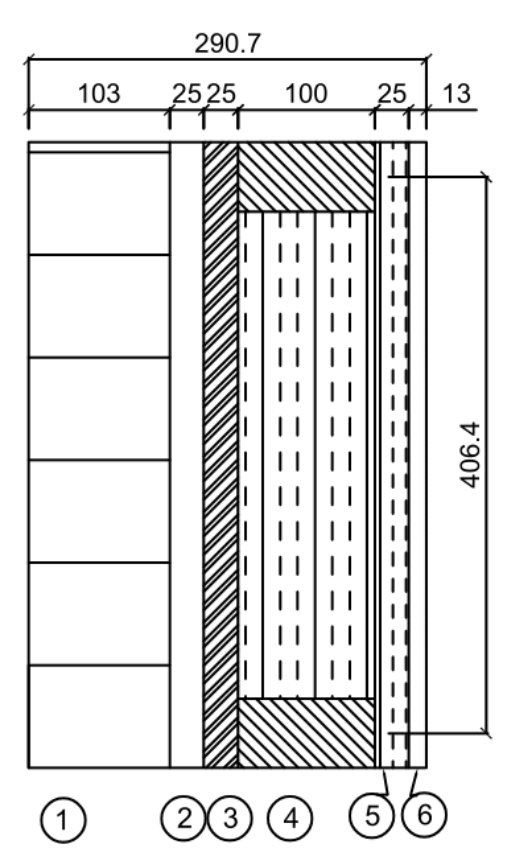

(1) Brick
Rehabilitation 3 Detail: $5.1 \mathrm{~m}^{2}-\mathrm{K} / \mathrm{W}$

(2) Air cavity with ties

(3) Wood sheathing

(4) Wood framing with

(5) Rigid PIR insulation

(6) Gypsum board

Units are in $\mathrm{mm}$

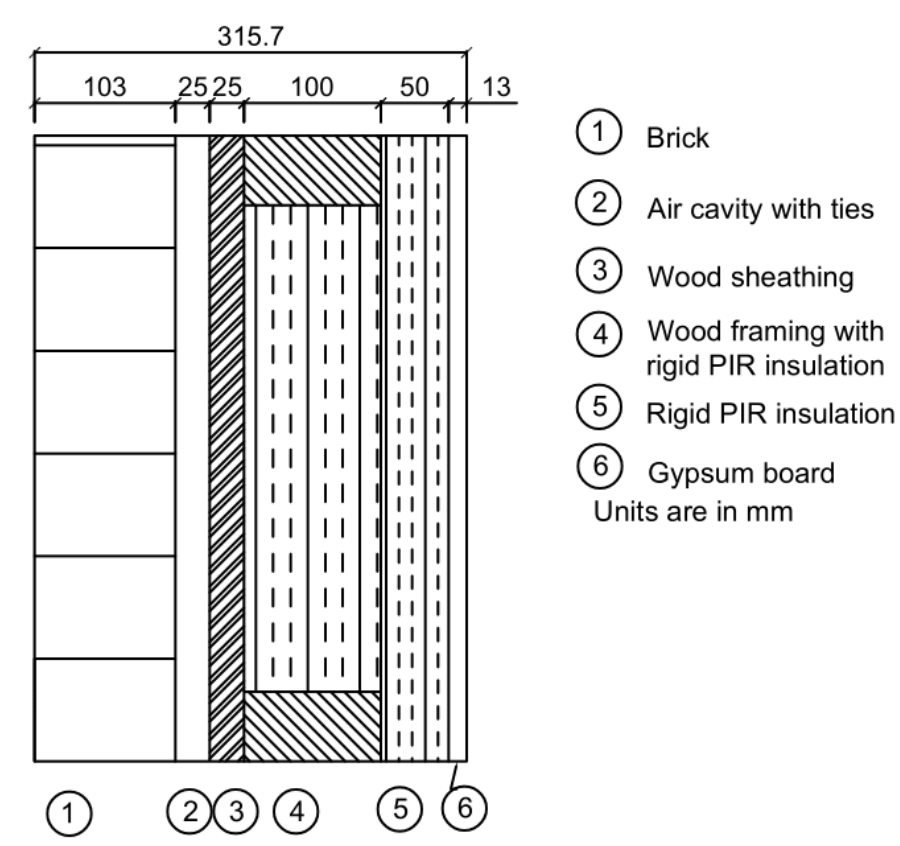

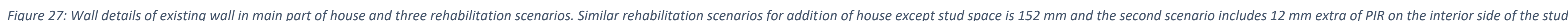
space. 
Table 4: Summary of retrofits explored, values simulated for analysis, and heritage impact assessment

\begin{tabular}{|c|c|c|c|c|c|}
\hline Energy retrofit & Current state & $\begin{array}{l}\text { Values for } \\
\text { analysis }\end{array}$ & Significance of element impacted & Scale of change & $\begin{array}{l}\text { Potential } \\
\text { overall impact } \\
\text { on heritage } \\
\text { values }\end{array}$ \\
\hline $\begin{array}{l}\text { Additional } \\
\text { insulation for } \\
\text { exterior walls }\end{array}$ & $2.2-2.6 \mathrm{~m}^{2}-\mathrm{K} / \mathrm{W}$ & $\begin{array}{l}3.0,4.1,5.1 \mathrm{~m}^{2}- \\
\mathrm{K} / \mathrm{W}\end{array}$ & $\begin{array}{l}\text { Low to high. The internal plaster is not } \\
\text { deemed a significant element. If the insulation } \\
\text { is incorrectly applied without consideration } \\
\text { for hygrothermal impact, then the high } \\
\text { significance exterior façade will be negatively } \\
\text { impacted. }\end{array}$ & Major & $\begin{array}{l}\text { Slight/Moderate } \\
\text { to Large/Very } \\
\text { Large }\end{array}$ \\
\hline $\begin{array}{l}\text { Reduce air } \\
\text { infiltration }\end{array}$ & $\begin{array}{l}14 \mathrm{ACH} \text { at } 50 \mathrm{~Pa} \\
\left(0.00781 \mathrm{~m}^{3} / \mathrm{s} / \mathrm{m}^{2} \text { at }\right. \\
50 \mathrm{~Pa}, 1.54 \mathrm{cfm} / \mathrm{ft}^{2} \text { at } \\
50 \mathrm{~Pa})\end{array}$ & $\begin{array}{l}\text { By } 30 \% \text { to } 80 \% \\
(9.8 \text { to } 2.8 \mathrm{ACH} \\
\text { at } 50 \mathrm{~Pa})\end{array}$ & $\begin{array}{l}\text { Low. Air sealing should have a minimal } \\
\text { impact on aesthetic and may be beneficial to } \\
\text { aesthetic in the case of repointing and closing } \\
\text { large gaps in the envelope. The suggested } \\
\text { level of air infiltration does not pose indoor } \\
\text { air quality issues, especially with the } \\
\text { implementation of mechanical ventilation } \\
\text { from the air-source heat pump. }\end{array}$ & Moderate & Slight \\
\hline Window retrofits & $\begin{array}{l}\text { Historic wooden } \\
\text { frame, double pane, } \\
\text { U-value }=2.67 \\
\text { SHGC }=0.7\end{array}$ & $\begin{array}{l}\text { triple pane rehab, } \\
\text { triple pane }+ \text { low- } \\
\text { E coating rehab, } \\
\text { new triple pane } \\
\text { low-E coating } \\
\text { with argon gas }\end{array}$ & $\begin{array}{l}\text { High. The historic large bay windows are } \\
\text { character defining of the house and should be } \\
\text { conserved through rehabilitation (fixing } \\
\text { weights in frames and improving } \\
\text { airtightness). }\end{array}$ & Moderate to Major & $\begin{array}{l}\text { Large/Very } \\
\text { Large }\end{array}$ \\
\hline $\begin{array}{l}\text { Air-source heat } \\
\text { pump as } \\
\text { supplementary } \\
\text { heating supply }\end{array}$ & $\begin{array}{l}2013 \text { gas boiler, } \\
\text { efficiency }=0.7\end{array}$ & - & $\begin{array}{l}\text { Low. Adding the air-source heat pump units } \\
\text { in the house should have minimal aesthetic } \\
\text { impact and it will greatly improve occupant } \\
\text { comfort by providing controlled heating and } \\
\text { cooling. The historic radiators will not be } \\
\text { removed to implement the air-source heat } \\
\text { pump. }\end{array}$ & Minor & Neutral/Slight \\
\hline
\end{tabular}




\begin{tabular}{|l|l|l|l|l|}
\hline $\begin{array}{l}\text { Daylight sensors } \\
\text { and controls }\end{array}$ & None & $\begin{array}{l}>500 \text { lux turn } \\
\text { lights off }\end{array}$ & $\begin{array}{l}\text { Negligible. The lighting and light fixtures are } \\
\text { not character defining of this house. Making } \\
\text { use of the daylight will maintain this } \\
\text { inherently sustainable feature of the house. }\end{array}$ & Negligible \\
\hline $\begin{array}{l}\text { Additional PV } \\
\text { power generation }\end{array}$ & $11.4 \mathrm{kWh} / \mathrm{m}^{2}$ & $\begin{array}{l}\text { Additional } 26 \\
\mathrm{kWh} / \mathrm{m}^{2}\end{array}$ & $\begin{array}{l}\text { High. The PV panels will be added to the top } \\
\text { of the mansard roof which is not visible from } \\
\text { the ground. This is easily reversible if } \\
\text { required. }\end{array}$ & $\begin{array}{l}\text { Minor } \\
\text { Appliance upgrade }\end{array}$ \\
\hline $\begin{array}{l}\text { No sensors and } \\
\text { controls for plugs. } \\
\text { Some appliances } \\
\text { upgraded } 2014 \text { to } \\
\text { 2018. }\end{array}$ & $\begin{array}{l}\text { 27.5\% appliance } \\
\text { energy savings } \\
\text { due to upgrades }\end{array}$ & $\begin{array}{l}\text { Negligible. Sensors and controls would be } \\
\text { added to appliance plugs and some appliances } \\
\text { may be replaced with new more efficient } \\
\text { appliances. }\end{array}$ & Minor \\
\hline
\end{tabular}

Note: The window rehabilitation involves adding interior storm windows. 


\subsection{Building Science Considerations}

Since there are changes to the thermal resistance and vapour permeability of the wall assembly, the risk of moisture accumulation needs to be considered. If moisture accumulates within the walls, then the thermal resistance will be decreased and there will be a potential for mould growth if the moisture is present for a prolonged period (Straube \& Schumacher, 2007). Additionally, if moisture accumulation occurs within the brick layer past the critical saturation point, then there will be freeze thaw damage during the winter. To consider the moisture accumulation, vapour diffusion through the wall, RH (relative humidity) at each interface between materials, and the rate of condensation need to be calculated. One way to minimize the vapour diffusion from the interior to the exterior in a cold climate and prevent moisture accumulation is to add a vapour barrier to the inner side of the insulation layer.

Vapour diffusion calculations were done using the simple Glaser Method, which uses psychometrics and are an estimate of whether there will be moisture accumulation due to vapour diffusion based on assumptions (Appendix F). The aluminum foil on the PIR insulation acts as a vapour barrier and provides a vapour resistance of $0.35 \mathrm{~Pa}-\mathrm{s}-\mathrm{m}^{2} / \mathrm{ng}$. The outdoor conditions of $-20^{\circ} \mathrm{C}$ and $75 \% \mathrm{RH}$ were chosen for Ottawa as a worse case where the temperature is lower than average, and RH is higher than average. Indoor conditions are assumed to be $21^{\circ} \mathrm{C}$ and $35 \% \mathrm{RH}$, and the insulation has a thermal resistance of 3.7 RSI. With these conditions there is no condensation plane within the wall assembly (RH does not exceed $80 \%-100 \%$ ), indicating no concern for moisture issues. The relative humidity within the wall assembly reaches a maximum of $72 \%$ in the brick layer under

these conditions. The vapour barrier solves the issue of moisture accumulation in the 
insulation. For this reason, if insulation is added, it is also recommended to add a vapour barrier on the interior side of the insulation layer to minimize vapour diffusion through the wall from the interior.

\subsection{Ranking of Options and Recommended Package}

A parametric analysis aided in the ranking of retrofit options. The results of the parametric analysis are shown in Figure 28 which are relative to the calibrated model. The modelled air-source heat pump produces the highest individual annual energy savings of about $29 \%$ of the total baseline energy use. The additional PV panels offset electricity energy use by $17 \%$. Reducing air infiltration by $80 \%$ resulting in $2.8 \mathrm{ACH}$ at $50 \mathrm{~Pa}\left(0.00156 \mathrm{~m}^{3} / \mathrm{s} / \mathrm{m}^{2}\right.$ at $50 \mathrm{~Pa}$ or $0.31 \mathrm{cfm} / \mathrm{ft}^{2}$ at $50 \mathrm{P} \mathrm{a}$ ) achieves the next highest energy savings of about $13 \%$. A thermal resistance of $5.1 \mathrm{~m}^{2}-\mathrm{K} / \mathrm{W}$ in the main house exterior walls achieves $12 \%$ energy savings. Reducing air infiltration by $70 \%$ and insulation to achieve $4.1 \mathrm{~m}^{2}-\mathrm{K} / \mathrm{W}$ walls also achieve significant energy savings of $11 \%$ and $9 \%$. New triple pane low-E argon windows and rehabilitated triple plane low-E windows both achieve 4\% energy savings. Insulating the basement floor to a high level of 6.0 RSI only achieves $2 \%$ energy savings, so it was not considered for the retrofit packages because of its invasiveness and low energy savings. Daylight controls save about $1 \%$ energy through the reduction of electrical lighting use and has no impact on the heritage character of the building, so it was considered for the retrofit packages. Increasing insulation in the addition of the house achieved only $1 \%$ energy savings due to the smaller surface area and higher starting level of insulation. It was recently insulated in 2017 , so it is also not practical to retrofit the walls of the addition of the house again (time, money, disturbance to occupants). Specific envelope improvements

were selected based on the sensitivity of a retrofit on the energy savings; for example, if 
the walls are to be insulated, it can be insulated to $4.1 \mathrm{~m}^{2}-\mathrm{K} / \mathrm{W}$ instead of $5.1 \mathrm{~m}^{2}-\mathrm{K} / \mathrm{W}$ because of the small change in savings $(3 \%)$.

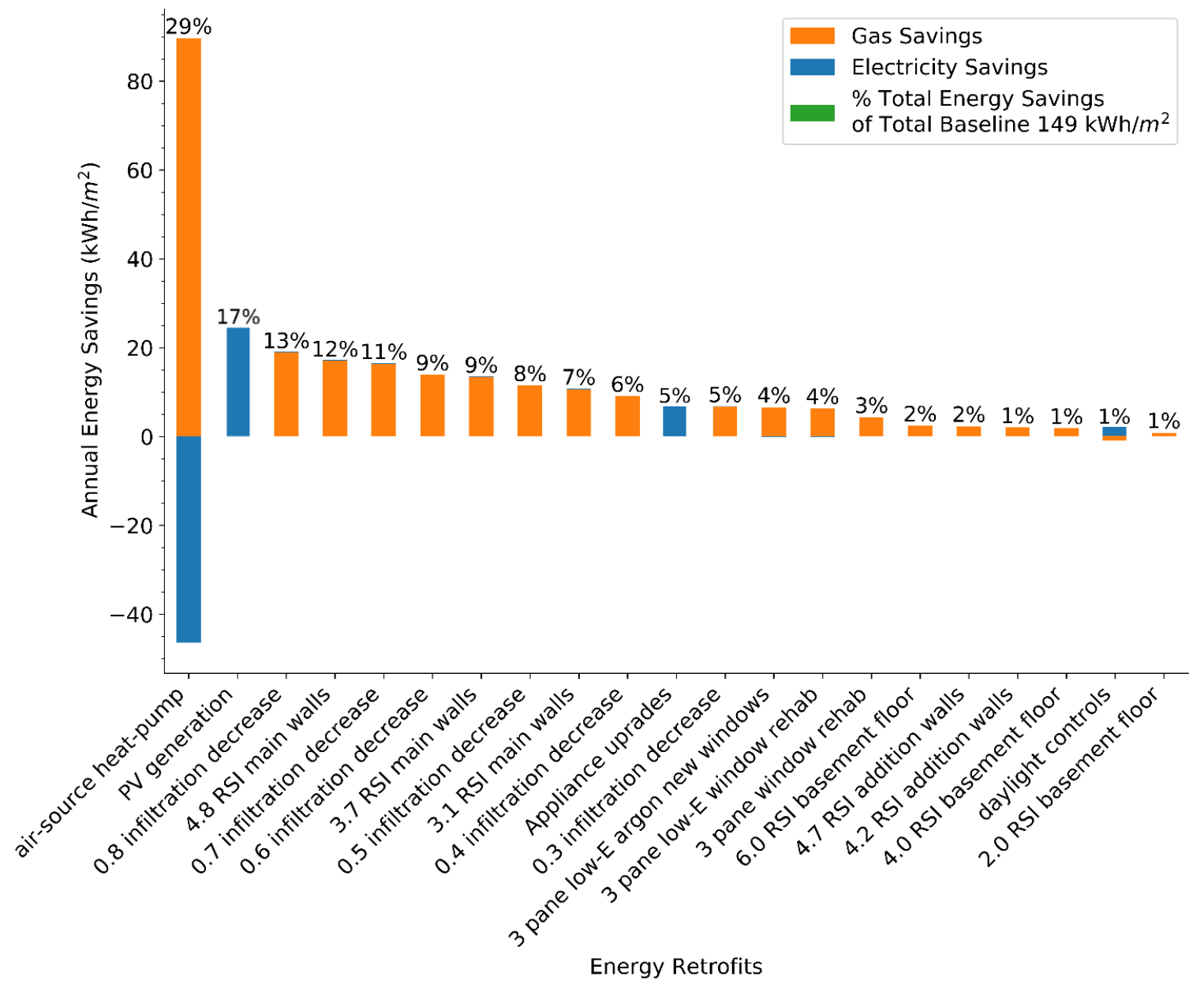

Figure 28: Results of parametric analysis of retrofit options. Thermal resistances are indicated for the level of insulation, not the effective thermal resistance of the entire wall assembly. This baseline considers the current PV generation of $11.4 \mathrm{kWh} / \mathrm{m} 2 /$ year. The window rehabilitation involves adding interior storm windows.

The retrofits that are viable from a sustainability and heritage perspective were combined and simulated to demonstrate the potential energy savings. Two different packages were simulated to compare the energy savings of highest feasible savings to a package which balances heritage conservation with energy reduction targets. A third option would be the minimal intervention approach of air sealing large cracks in the envelope without any other upgrades, which is assumed to achieve a $40 \%$ reduction in air-leakage. This minimal 
intervention option would only achieve about $6 \%$ energy savings, which is not adequate for achieving deep energy savings. The best energy savings package (air-source heat pump, $80 \%$ reduction in air leakage to $2.8 \mathrm{ACH}$ at $50 \mathrm{~Pa}, 5.1 \mathrm{~m}^{2}-\mathrm{K} / \mathrm{W}$ exterior walls, new triple pane low-E argon windows, daylighting controls, additional $26 \mathrm{kWh} / \mathrm{m}^{2} \mathrm{PV}$ power generation, and $27.5 \%$ appliance improvement) achieved $74 \%$ energy savings and a $24 \%$ increase in number of hours that the temperature setpoints are met.

The package that balanced heritage conservation and energy reductions implemented an air-source heat pump, reduced air infiltration by $70 \%$ to $4.2 \mathrm{ACH}$ at $50 \mathrm{~Pa}$ $\left(0.00234 \mathrm{~m}^{3} / \mathrm{s} / \mathrm{m}^{2}\right.$ at $50 \mathrm{~Pa}$ or $0.46 \mathrm{cfm} / \mathrm{ft}^{2}$ at $\left.50 \mathrm{~Pa}\right)$, insulated to have $4.1 \mathrm{~m}^{2}-\mathrm{K} / \mathrm{W}$ exterior walls, used the existing windows with interior storm windows to achieve triple pane lowE windows, daylight controls, and $27.5 \%$ appliance improvement. A $70 \%$ reduction in air leakage is likely more feasible in this house based on the construction and should not require the removal of the character defining chimney. The lower level of insulation still achieves a considerable amount of savings and increases the wall thickness by $15.5 \mathrm{~mm}$, which results in a total of $1.62 \mathrm{~m}^{2}$ of lost floor area (ground floor, level 1 and level 2) compared to $4.32 \mathrm{~m}^{2}$ of lost floor area for the higher level of insulation, which increases the wall thickness by $40.5 \mathrm{~mm}$. The new window frames compared to rehabilitated windows do not have a difference in energy savings and achieve a lower than $10 \%$ energy savings, so it does not make sense to risk impacting the heritage character with new window assemblies. For this reason, interior storm windows that follow the aesthetic but are distinct from the existing windows are a good option to improve the window assemblies. This second package achieved 71\% energy savings (Figure 29) and a 30\% increase in number of hours that the temperature setpoints are met. The incremental savings of each option 
demonstrates that it is crucial to simulate combinations of retrofits to get an accurate estimate of total savings and impact of each retrofit when packaged with others.

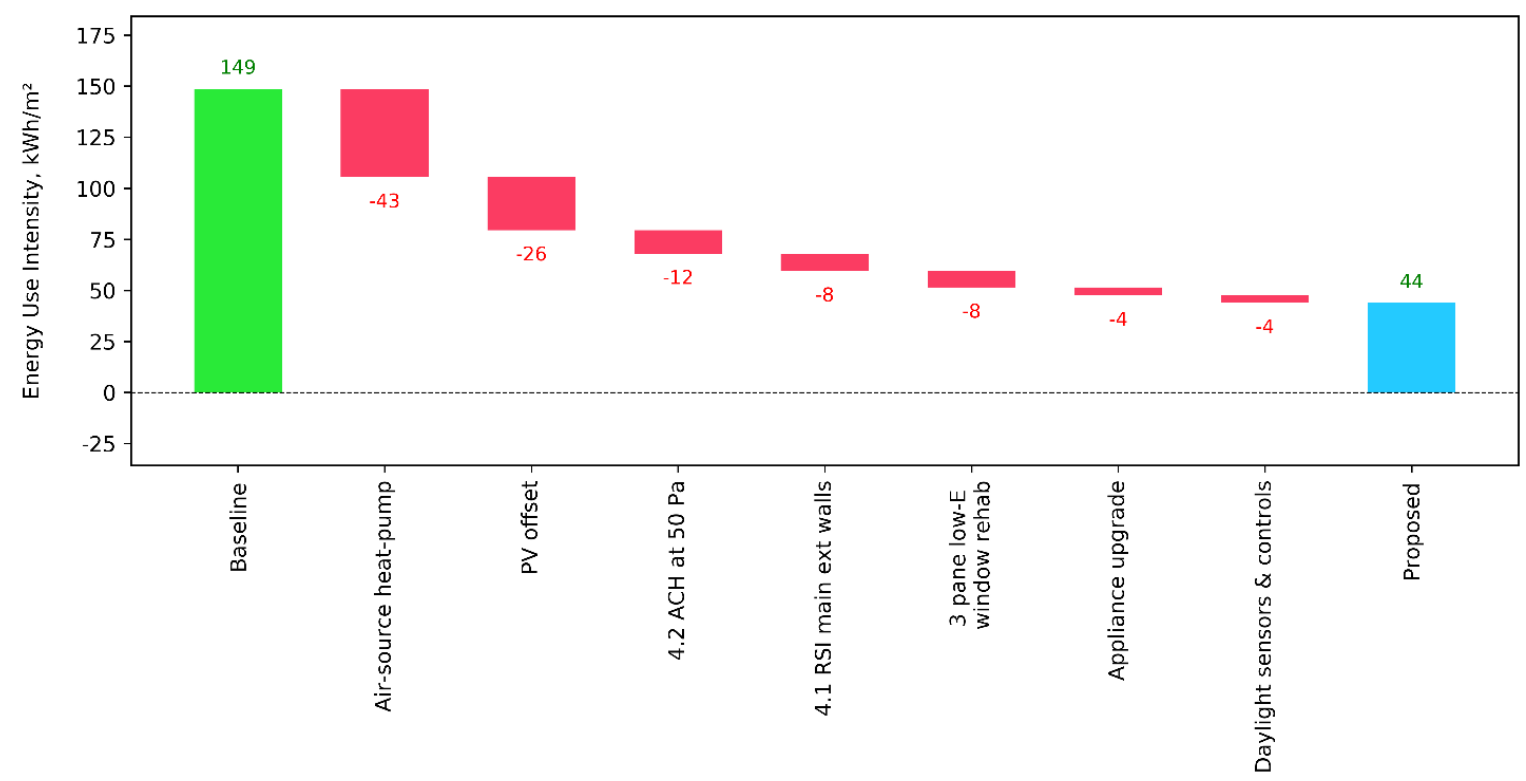

Figure 29: Incremental annual energy savings of package of retrofits that balances heritage conservation and energy reduction target relative to calibrated baseline. The window rehabilitation involves adding interior storm windows.

\subsection{Discussion}

The incremental energy savings of the recommended retrofits shown in Figure 29 demonstrate that upgrading the HVAC system and reducing air infiltration into the house are the most important retrofit measures to implement. Reducing the air infiltration to 4.2 $\mathrm{ACH}$ at $50 \mathrm{~Pa}$ (70\% reduction) was recommended because any lower is unlikely to be feasible in the house due to the air leakage pathways in the existing construction. Obtaining this level of airtightness would require the addition of an air-vapour barrier within the envelope. The hole in the basement, the chimney, and other problem areas should be sealed to achieve this level of airtightness. When air sealing the chimney, the fireplace should be conserved as a decorative character-defining element. Since the benefit of adding insulation is greater than the capital cost shown in literature, it should be implemented 
along with the addition of an air-vapour barrier to prevent moisture issues in the envelope. These recommended envelope retrofits will need to be done with care to conserve the historic mouldings around windows and doorways.

Greater energy savings from the air-source heat pump compared to other retrofits were expected since replacing older HVAC equipment was found to have the greatest energy savings in literature (see Table 1). The air-source heat pump increases electricity use by $14 \mathrm{kWh} / \mathrm{m}^{2} /$ year when combined with envelope, lighting, and appliance retrofits, whereas when implemented alone, it increases electricity use by $47 \mathrm{kWh} / \mathrm{m}^{2} /$ year. This demonstrates the importance of retrofitting the envelope before applying HVAC retrofits, so the systems can be reduced in size and operate efficiently. A ductless air-source heat pump should not be an invasive retrofit for the heritage values of the building, and it improves the comfort of occupants by providing cooling in the summer, making the building more sustainable long-term. The additional PV panels with all other retrofits results in the electricity use stays about the same at $27 \mathrm{kWh} / \mathrm{m}^{2} /$ year.

The end use breakdown for the recommended retrofits is shown in Figure 30 (excluding renewables). The gas energy used for heating can be reduced to 3.3 $\mathrm{kWh} / \mathrm{m}^{2} / \mathrm{year}$. After retrofit, the most carbon intensive source of energy use is the DHW, heated using natural gas ${ }^{6}$, which can be reduced with an integrated air-source heat pump

${ }^{6}$ The carbon intensity depends on region; in Ontario, Canada, the annual marginal emission factor of electricity is about $0.134 \mathrm{kgCO}_{2} / \mathrm{kWh}$ (Sotes, 2019) and $0.525 \mathrm{kgCO}_{2} / \mathrm{kWh}$ for natural gas (Intrinsik Corp., 2016). 
system. Further reductions in electricity can be achieved using a smart thermostat, which was not modelled due to uncertainties in occupant behaviour.

The trade-offs between the heritage conservation and energy reduction objectives are minimal and ensure that society continues to thrive through the connection to a sense of place, as promoted in Sustainable Development Goal 11.4 (United Nations, 2019), and through minimal impact on the environment. The package that balances heritage and energy savings vs the package that maximizes energy savings achieves a greater level of comfort by $6 \%$ due to greater levels of comfort during the summer. If a retrofit option involves a greater intervention, then the energy savings must be great enough, and this option must not have a detrimental impact on the heritage values of the site. The change in hygrothermal behaviour can be considered in more detail through hygrothermal modelling to minimize potential moisture issues when the building envelope conditions are drastically changed.

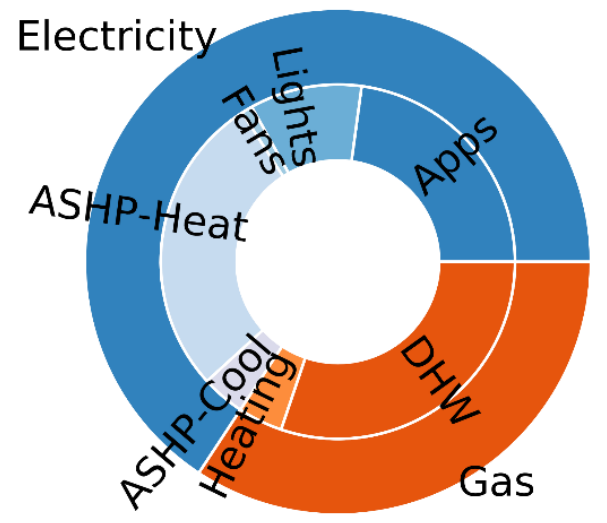

$\begin{array}{lll} & \text { EUI }\left(\mathrm{kWh} / \mathrm{m}^{2} / \mathrm{a}\right) & \text { Percentage } \\ \text { ASHP-Cool: } & 3.2 & 3.9 \% \\ \text { ASHP-Heat: } & 22.4 & 27.6 \% \\ \text { Fans: } & 0.8 & 1.0 \% \\ \text { Pumps: } & 0.2 & 0.2 \% \\ \text { Lights: } & 8.3 & 10.2 \% \\ \text { Appliances: } & 18.5 & 22.8 \% \\ \text { DHW: } & 24.4 & 30.1 \% \\ \text { Gas Heat: } & 3.3 & 4.1 \%\end{array}$

Figure 30: End use breakdown for recommended retrofits combined. Pumps are not shown in the pie chart because their energy use is close to zero. 


\subsection{Conclusion}

About $71 \%$ energy savings and $30 \%$ improvement in comfort can be achieved in an historic single-detached house in a cold climate through deep energy retrofits of the building envelope, the HVAC systems, lighting controls, and the addition of on-site renewable energy, while conserving the character defining elements of the house. A balance between energy savings, sustainability, occupant comfort, and heritage conservation was achieved using the methodology and decision framework presented. The recommended retrofits include reducing air infiltration by $70 \%$ to $4.2 \mathrm{ACH}$ at $50 \mathrm{~Pa}$, adding insulation and an airvapour barrier to achieve $4.1 \mathrm{~m}^{2}-\mathrm{K} / \mathrm{W}$ exterior walls, repairing and rehabilitating the windows to triple pane low-E windows, the addition of an air-source heat pump for supplemental heating, daylighting sensors and controls, appliance sensors and controls, and additional on-site solar PVs.

The results of this study may be representative for houses of similar construction and age in the Glebe neighbourhood; therefore, these retrofits may be applied to other houses for larger scale energy reductions within Ottawa and potentially other cold climate North American cities. The methodology in this study may be applied to retrofits for all types of existing buildings to provide more holistic sustainability retrofit recommendations. The results of this study suggest that the presented methodology and decision framework facilitate deep energy retrofits in historic residential homes in a cold climate, while conserving the heritage values of the historic house. In most cases, the energy retrofits 
benefitted heritage conservation values and occupant comfort demonstrating how heritage conservation can play a key role in sustainable development.

\section{Cost Analysis}

A cost analysis was conducted to compare the operational costs of the baseline and retrofit scenarios and determine the simple payback for the capital costs (purchase and installation) of the retrofit package.

\subsection{Methodology}

The methodology for the cost analysis was to estimate capital costs for each retrofit measure, cost savings as a result of operational energy savings and a simple payback for the entire retrofit package to give the client/owner an idea of costs and payback. This cost analysis does not consider inflation, taxes, or maintenance costs. A reasonable payback period might be around 10-15 years. Since components will not need to be replaced within 25 years of installation this simplifies the analysis.

\subsubsection{Capital Costs}

Capital costs were determined from previous retrofits conducted on the house (considering inflation to 2020), local contractor websites, and economic studies. The carbon tax is assumed to be $\$ 50 /$ ton $\mathrm{CO}_{2}$ presuming that the retrofits are implemented in 2022. The final capital cost considers the carbon tax cost of $\$ 50 /$ ton $\mathrm{CO}_{2}$ by subtracting the tax for the associated carbon savings of 150 tonnes over 20 years (see Section 8 for details of carbon savings). Table 5 shows the capital costs for retrofits which includes material/equipment and labour/installation. The windows had the highest capital cost of all the building retrofits. For this reason, three different window options were considered to 
see if capital cost could be reduced. The first option explored was a rehabilitation of the existing windows and adding a storm window with low-E coating. Since windows are now usually constructed as double pane units, this was considered as the storm window. The second option explored was the rehabilitation of the existing windows and adding only a low-E film to the interior side of the glazing. Purchasing costs were calculated by multiplying the cost per unit by the number of units. 
Table 5: Capital costs of individual retrofits (costs are in CAD\$)

\begin{tabular}{|c|c|c|c|c|c|c|}
\hline Retrofit & Cost per Unit & Number of Units & $\begin{array}{l}\text { Purchase } \\
\text { Cost }\end{array}$ & $\begin{array}{l}\text { Labour } \\
\text { Cost }\end{array}$ & $\begin{array}{l}\text { Total Capital } \\
\text { Cost } \\
\end{array}$ & Source \\
\hline $\begin{array}{l}\text { Air-source heat-pump } \\
\text { (mini split ductless) }\end{array}$ & \$2250/unit & 4 & $\$ 9,000$ & $\$ 4,000$ & $\$ 13,000$ & $\begin{array}{l}\text { ("Home Stars Get a Quote," } \\
\text { 2020; Kegel et. al, 2012) }\end{array}$ \\
\hline $\begin{array}{l}\text { Air tightening envelope } \\
\text { (weather stripping and } \\
\text { filling in large holes in } \\
\text { envelope) }\end{array}$ & $\$ 250 /$ house & 1 & $\$ 250$ & & $\$ 250$ & (Keller-Herzog, 2018a) \\
\hline $\begin{array}{l}\text { Adding } 125 \mathrm{~mm} \text { PIR (3.7 } \\
\text { RSI) insulation to achieve } \\
\text { 4.1 RSI wall assembly }\end{array}$ & $\$ 0.254 / \mathrm{m}^{2}-\mathrm{mm}$ & $\begin{array}{l}271.77 \mathrm{~m}^{2} \text { exterior } \\
\text { walls*125 } \mathrm{mm} \\
\text { insulation }\end{array}$ & $\$ 8,635$ & $\$ 3465$ & $\$ 12,100$ & $\begin{array}{l}\text { (Palmer, 2017; "PIR Boards," } \\
\text { 2019) }\end{array}$ \\
\hline $\begin{array}{l}\text { Rehab/retrofit historic } \\
\text { windows + low-E coating } \\
\text { (option } 1 \text { ) }\end{array}$ & $\begin{array}{l}\$ 175 \text { rehab/window } \\
\$ 826.50 \text { retrofit/ } \\
\text { window }\end{array}$ & 20 windows & $\$ 20,730$ & & $\$ 20,730$ & $\begin{array}{l}\text { (Irving, 2019; "Window } \\
\text { Replacement Cost Estimator," } \\
\text { 2019) }\end{array}$ \\
\hline $\begin{array}{l}\text { Only low-E film and rehab } \\
\text { of windows (option 2) }\end{array}$ & $\begin{array}{l}\$ 175 \mathrm{rehab} / \text { window } \\
\$ 53.82 / \mathrm{m}^{2}\end{array}$ & $\begin{array}{l}20 \text { windows, } 39.13 \\
\mathrm{~m}^{2} \text { window area }\end{array}$ & $\$ 6,305$ & & $\$ 6,300$ & (Debusk, 2012; Irving, 2019) \\
\hline $\begin{array}{l}\text { Only repair/rehab windows } \\
\text { (option 3) }\end{array}$ & $\$ 175$ rehab/window & 20 windows & $\$ 3,500$ & & $\$ 3,500$ & (Irving, 2019) \\
\hline $\begin{array}{l}\text { Daylight sensors and } \\
\text { controls }\end{array}$ & $\begin{array}{l}\$ 394 \text { for a school, } \\
\text { assume } 25 \% \text { of the cost } \\
\text { for a house }\end{array}$ & 1 & $\$ 98.50$ & & $\$ 99$ & $\begin{array}{l}\text { (Wireless Lighting Controls, } \\
\text { 2016) }\end{array}$ \\
\hline $\begin{array}{l}\text { Appliance plug sensors } \\
\text { and controls }\end{array}$ & $\begin{array}{l}\$ 0.00 \text { because province } \\
\text { installs smart metering }\end{array}$ & & $\$ 0.00$ & & $\$ 0.00$ & (Armel et. al, 2013) \\
\hline Additional PV panels & \$ 320.67/panel & 20 panels & $\$ 6413$ & $\$ 7723$ & $\$ 14,140$ & $\begin{array}{l}\text { (“Canadian Solar,” 2020; } \\
\text { "Cost of Solar Power In } \\
\text { Canada," 2019) }\end{array}$ \\
\hline \multicolumn{5}{|c|}{ Total with option 1 window retrofit with storm window } & \multicolumn{2}{|l|}{$\$ 59,620$} \\
\hline \multicolumn{5}{|c|}{ Total with option 1, minus carbon tax $\left(\$ 50 /\right.$ ton $\mathrm{CO}_{2}$ saved $)$} & \multicolumn{2}{|l|}{$\$ 52,320$} \\
\hline \multicolumn{5}{|c|}{ Total with option 2 window repair and rehabilitation with low-E coating } & \multicolumn{2}{|l|}{$\$ 45,190$} \\
\hline \multicolumn{5}{|c|}{ Total with option 2, minus carbon tax $\left(\$ 50 /\right.$ ton $\mathrm{CO}_{2}$ saved $)$} & \multicolumn{2}{|l|}{$\$ 37,890$} \\
\hline \multicolumn{5}{|c|}{ Total with option 3 window repair/rehabilitation } & \multicolumn{2}{|l|}{$\$ 43,090$} \\
\hline \multicolumn{5}{|c|}{ Total with option 3 , minus carbon tax $\left(\$ 50 /\right.$ ton $\mathrm{CO}_{2}$ saved) } & \multicolumn{2}{|l|}{$\$ 35,790$} \\
\hline
\end{tabular}

Note: The purchase cost includes the combined cost of materials/equipment and labour if no labour cost given. 


\subsubsection{Operational Costs}

The amount of energy used during each hour of the day in winter and summer were summed to calculate the different time of use costs. Table 6 shows the total winter and summer on/off/mid peak hours and electricity costs for the different times of use in Ontario. The retrofit results in a $\$ 384$ cost increase and $\$ 52$ decrease ( $\$ 332$ total increase) attributed to electrical heating and cooling supplied by the air-source heat-pump.

Table 7 gives the cost breakdown for Enbridge gas energy use in Ontario. The gas pricing was multiplied by the total volume $\left(\mathrm{m}^{3}\right)$ of gas used each month. The volume of gas was calculated from energy simulation output using a conversion of $10.33 \mathrm{kWh} / \mathrm{m}^{3}$ (NRCan, 2015). Table 8 shows the monthly cost of gas energy use for the baseline and retrofit options. The cost savings from gas operation after retrofit are $\$ 1057$ annually.

Table 6: Total on/off/mid peak hours and electricity time of use costs for baseline and retrofit

\begin{tabular}{|c|c|c|c|c|c|c|}
\hline \multirow{2}{*}{ Season } & \multirow[b]{2}{*}{ Time of Use } & \multirow[b]{2}{*}{$\begin{array}{l}\text { Price } \\
(\$ / k W h)\end{array}$} & \multicolumn{2}{|c|}{ Energy (kWh) } & \multicolumn{2}{|c|}{ Operational Cost (\$) } \\
\hline & & & Baseline & Retrofit & Baseline & Retrofit \\
\hline \multirow[t]{5}{*}{ Winter } & $\begin{array}{l}\text { off peak weekdays } \\
1-7 \mathrm{hrs}, 19-24 \\
\text { hrs }\end{array}$ & 0.065 & 1731 & 3906 & $\$ 113$ & $\$ 254$ \\
\hline & $\begin{array}{l}\text { on peak weekdays } \\
7-11 \mathrm{hrs}, 17-19 \\
\text { hrs }\end{array}$ & 0.132 & 1590 & 2300 & $\$ 210$ & $\$ 304$ \\
\hline & $\begin{array}{l}\text { mid peak weekdays } \\
11-17 \mathrm{hrs}\end{array}$ & 0.095 & 1391 & 1917 & $\$ 132$ & $\$ 182$ \\
\hline & $\begin{array}{l}\text { off peak weekend } \\
1-24 \mathrm{hrs}\end{array}$ & 0.065 & 1958 & 3483 & $\$ 127$ & $\$ 226$ \\
\hline & Total & - & 6670 & 11605 & $\$ 582$ & $\$ 966$ \\
\hline \multirow[t]{5}{*}{ Summer } & $\begin{array}{l}\text { off peak weekdays } \\
1-7 \mathrm{hrs}, 19-24 \\
\text { hrs }\end{array}$ & 0.077 & 1651 & 1776 & $\$ 127$ & $\$ 137$ \\
\hline & $\begin{array}{l}\text { on peak weekdays } \\
11-17 \mathrm{hrs}\end{array}$ & 0.157 & 1358 & 1308 & $\$ 213$ & $\$ 205$ \\
\hline & $\begin{array}{l}\text { mid peak weekdays } \\
7-11 \mathrm{hrs}, 17-19 \\
\text { hrs }\end{array}$ & 0.113 & 1569 & 1395 & $\$ 177$ & $\$ 158$ \\
\hline & $\begin{array}{l}\text { off peak weekend } \\
1-24\end{array}$ & 0.065 & 2257 & 1733 & $\$ 147$ & $\$ 113$ \\
\hline & Total & - & 5184 & 5389 & $\$ 664$ & $\$ 612$ \\
\hline
\end{tabular}


Table 7: Gas price breakdown from utility bills

\begin{tabular}{|l|l|}
\hline Cost breakdown & Prices $\mathbf{( \$ \mathbf { m } 3 )}$ \\
\hline Delivery to customer & $\$ 0.13$ \\
\hline Site restoration clearance & $-\$ 0.01$ \\
\hline Transportation to Enbridge & $\$ 0.05$ \\
\hline Gas supply charge & $\$ 0.12$ \\
\hline Total & $\mathbf{\$ 0 . 2 9}$ \\
\hline
\end{tabular}

Table 8: Monthly gas cost for baseline and retrofit

\begin{tabular}{|l|l|l|l|l|l|l|}
\hline & \multicolumn{2}{|l}{ Baseline } & \multicolumn{2}{l|}{ Retrofit } \\
\hline Month & $\begin{array}{l}\text { Energy used } \\
\mathbf{( k W h )}\end{array}$ & $\begin{array}{l}\text { Energy } \\
\text { used }\left(\mathbf{m}^{\mathbf{3}}\right)\end{array}$ & Cost $\mathbf{( \$ )}$ & $\begin{array}{l}\text { Energy } \\
\text { used (kWh) }\end{array}$ & $\begin{array}{l}\text { Energy } \\
\text { used }\left(\mathbf{m}^{\mathbf{3}}\right)\end{array}$ & Cost (\$) \\
\hline Jan & 8083 & 782 & $\$ 224.2$ & 1736 & 168 & $\$ 48.15$ \\
\hline Feb & 6656 & 644 & $\$ 184.6$ & 1289 & 125 & $\$ 35.74$ \\
\hline Mar & 4689 & 454 & $\$ 130.1$ & 835.0 & 80.8 & $\$ 23.16$ \\
\hline Apr & 2747 & 266 & $\$ 76.18$ & 742.5 & 71.8 & $\$ 20.59$ \\
\hline May & 1574 & 152 & $\$ 43.66$ & 762.1 & 73.7 & $\$ 21.13$ \\
\hline Jun & 732 & 732 & $\$ 209.9$ & 439.5 & 42.5 & $\$ 12.19$ \\
\hline Jul & 692 & 67 & $\$ 19.19$ & 454.1 & 43.9 & $\$ 12.59$ \\
\hline Aug & 721 & 70 & $\$ 20.00$ & 454.1 & 43.9 & $\$ 12.59$ \\
\hline Sep & 1056 & 102 & $\$ 29.29$ & 222.4 & 21.5 & $\$ 6.17$ \\
\hline Oct & 2893 & 280 & $\$ 80.22$ & 764.9 & 74.0 & $\$ 21.21$ \\
\hline Nov & 4339 & 420 & $\$ 120.3$ & 743.7 & 72.0 & $\$ 20.62$ \\
\hline Dec & 6376 & 617 & $\$ 176.8$ & 844.3 & 81.7 & $\$ 23.42$ \\
\hline Total & $\mathbf{4 0 , 5 6 0}$ & $\mathbf{4 , 5 9 0}$ & $\mathbf{\$ 1 , 3 1 0}$ & $\mathbf{9 , 2 9 0}$ & $\mathbf{9 0 0}$ & $\$ \mathbf{2 6 0}$ \\
\hline
\end{tabular}

\subsection{Results and Discussion}

\subsubsection{Operational Cost Savings}

Table 9 shows a summary of the baseline and retrofit operational costs. Although electricity costs increase by $\$ 332$, the gas savings are $\$ 1057$, resulting in a total annual savings of \$724. New PVs on available site area (see Figure 31) were considered for the retrofit package to help offset costs and carbon emissions. Electricity generation from PVs was assumed to occur mostly during mid peak winter hours and summer on peak hours (11-17 hrs). Based on the average of 2015-2017 current PV generation, the generation split 
between winter and summer was estimated to be about $32 \%$ during the winter and $68 \%$ during the summer (see Appendix E for full power generation data). About 3.25 times greater annual operational savings of $\$ 2356$ are achieved when additional PVs generating $8608 \mathrm{kWh} /$ year are added.

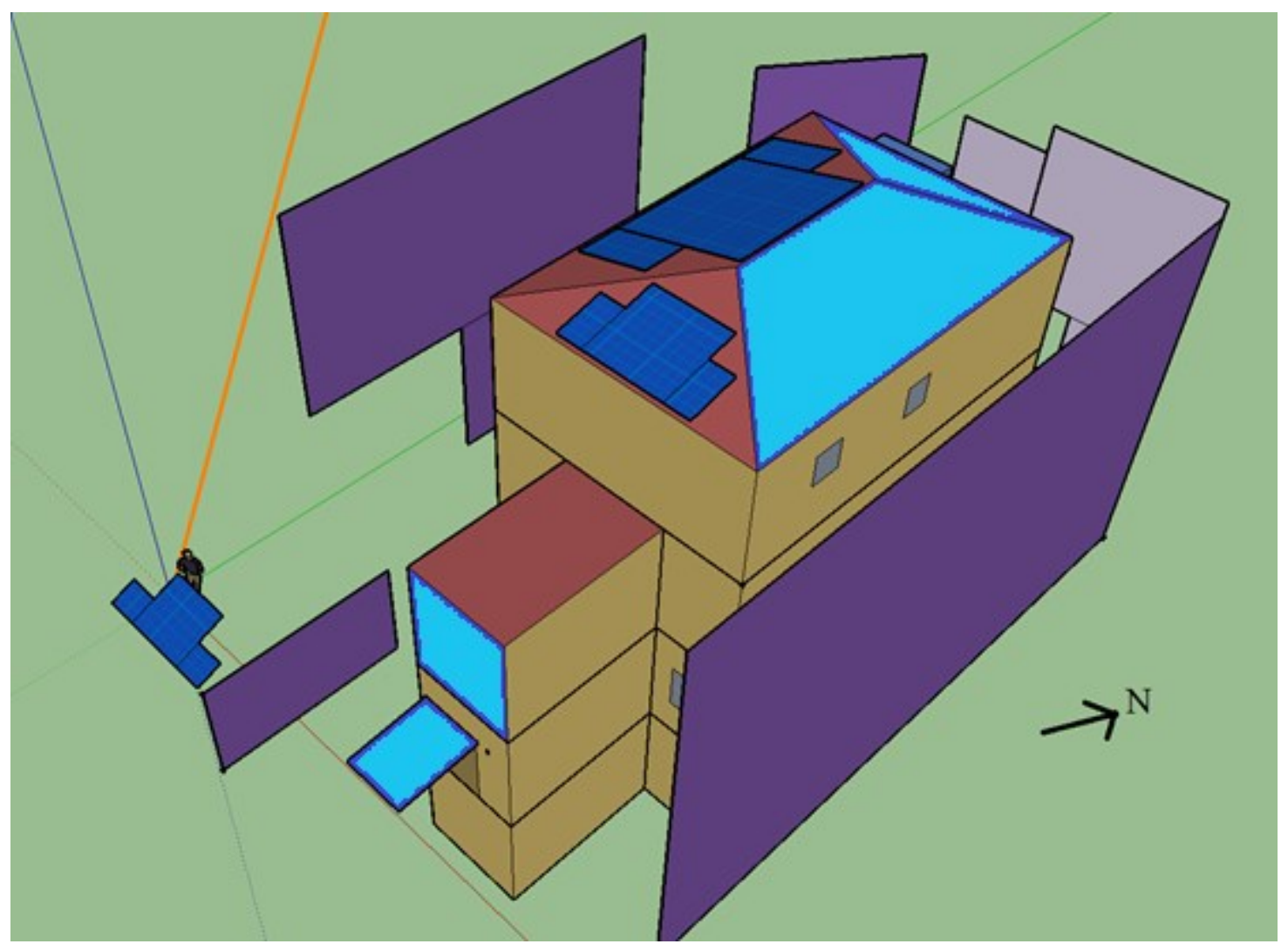

Figure 31: Available areas for new PVs shown as light blue surfaces, which were selected based on least amount of shading and most direct sunlight.

Table 9: Summary of baseline and retrofit operational costs

\begin{tabular}{|l|l|l|l|l|l|}
\hline $\begin{array}{l}\text { Operational Energy } \\
\text { Source }\end{array}$ & $\begin{array}{l}\text { Baseline } \\
\text { Costs }\end{array}$ & $\begin{array}{l}\text { Retrofit } \\
\text { Costs }\end{array}$ & $\begin{array}{l}\text { Annual } \\
\text { Savings }\end{array}$ & $\begin{array}{l}\text { Retrofit with } \\
\text { new PVs }\end{array}$ & $\begin{array}{l}\text { Annual } \\
\text { Savings }\end{array}$ \\
\hline Electricity & $\$ 1,250$ & $\$ 1,580$ & $-\$ 330$ & $-\$ 50$ & $\$ 1,300$ \\
\hline Gas & $\$ 1,310$ & $\$ 260$ & $\$ 1,060$ & $\$ 260$ & $\$ 1,060$ \\
\hline Total & $\$ 2,560$ & $\$ 1840$ & $\$ 720$ & $\$ 200$ & $\$ 2,360$ \\
\hline
\end{tabular}




\subsubsection{Payback Period}

A summary of the simple payback cost analysis is presented in Table 10 below. The simple payback for the retrofit package with the window rehabilitation ${ }^{7}$ is around 30 years, with the low-E film8 is around 33 years, and about 53 years for a full retrofit when the savings of renewables are not considered. With additional PVs, the capital cost increases but the simple payback period is shortened significantly to 15 years, 16 years, and 22 years for the three options. From a cost perspective, the retrofit package with option 3 of repairing the windows and adding PVs is the better option.

The estimated capital costs for this deep energy retrofit package of $\$ 43,085$ is within the estimated capital costs of $\$ 40,420+/-\$ 30,358$ USD from Brennan Less \& Jain Walker (2014). For cold climate deep energy retrofits, the same study found the cost of retrofits to be about $\$ 815 \mathrm{USD} / \mathrm{MMBtu}$ energy savings. The recommended retrofit package costs about $\$ 359 /$ MMBtu $(35,196 \mathrm{kWh}=120 \mathrm{MMBtu})$ energy savings, which is significantly cheaper than the study. This may be due to advancements in technology that lower purchasing costs from the time of the study to present. The lower costs are also likely because there were already some recent energy retrofits done on the house, so it was performing better than average.

${ }^{7}$ The reduction in energy savings for just the rehabilitation of windows is about $4 \%$ and was accounted for in the payback calculation.

${ }^{8}$ The reduction in energy savings for just the low-E coating is about $2 \%$ and was accounted for in the payback calculation. 
Table 10: Summary of simple payback for complete retrofit package considering different window retrofit options and carbon tax of $\$ 50 /$ ton $\mathrm{CO}_{2}$

\begin{tabular}{|l|l|l|l|l|l|l|}
\hline & $\begin{array}{l}\text { 1. Retrofit } \\
\text { windows }+ \\
\text { low-E film }\end{array}$ & $\begin{array}{l}\mathbf{2} \text { Rehab } \\
\text { existing } \\
\text { windows }+ \\
\text { low-E film }\end{array}$ & $\begin{array}{l}\text { 3. Rehab } \\
\text { existing } \\
\text { windows }\end{array}$ & $\begin{array}{l}\text { New PVs }+ \\
\text { option 1 }\end{array}$ & $\begin{array}{l}\text { New PVs } \\
+ \text { option 2 }\end{array}$ & $\begin{array}{l}\text { New PVs } \\
+ \text { option } \\
\mathbf{3}\end{array}$ \\
\hline $\begin{array}{l}\text { Total } \\
\text { capital cost }\end{array}$ & $\$ 45,480$ & $\$ 31,050$ & $\$ 28,950$ & $\$ 59,620$ & $\$ 45,190$ & $\$ 43,090$ \\
\hline $\begin{array}{l}\text { Total cost } \\
\text { minus } \\
\text { carbon tax }\end{array}$ & $\$ 38,180$ & $\$ 23,760$ & $\$ 21,650$ & $\$ 52,320$ & $\$ 37,890$ & $\$ 35,790$ \\
\hline $\begin{array}{l}\text { Simple } \\
\text { payback } \\
\text { period } \\
\text { (years) }\end{array}$ & $\mathbf{5 3}$ & $\mathbf{3 3}$ & $\mathbf{3 0}$ & $\mathbf{2 2}$ & $\mathbf{1 6}$ & $\mathbf{1 5}$ \\
\hline
\end{tabular}

\subsubsection{Considerations}

Cost calculations do not consider taxes, inflation in future years, discount rates, or rate of return on investment. The calculations for PV generation were simplified due to time constraint and are only an estimate of the potential energy generation of new solar panels. Miscellaneous array and power conditioning losses were assumed to be $5 \%$. The Maxpower CS6X-310 PV panels were considered because they are a good option for Canada with high inverter efficiency of $97 \%$ and durability against environmental deterioration (PV Module Product Datasheet, 2017). The payback period may be greater or less depending on real capital costs and power generation from PV arrays.

\subsection{Conclusion}

The recommended package of retrofits with the simple repair of the existing windows has a simple payback period of 15 years. This payback period was possible with the additional savings of new solar PV panels installed on available site area and considering the cost of carbon emissions (carbon tax). The recommended retrofit package is viable if the capital 
costs of $\$ 43,085$ can be paid by the homeowner. Government incentives and policies can aid in the cost feasibility of homeowners implementing deep energy retrofits.

\section{Carbon Analysis}

Athena Impact Estimator for Buildings was used for the embodied carbon analysis to compare the embodied carbon of the retrofits to the carbon savings of reducing the energy use.

\subsection{Methodology}

The location of the building is input to consider the location's electricity grid and transportation of materials. The carbon intensities of power generation sources in Athena reflect the industry average efficiencies in North America and grid mix depends on location. The location is also used to determine transportation modes and distances, and technologies for product manufacturing. A regional market share analysis is conducted to determine the source location of products. Ecoinvent 3.4 electricity data is used to determine carbon intensity of electricity grids for Canadian provinces.

The building height is input for estimates of crane use if necessary. The building type selected was single family residential which impacts the maintenance of the building in the software. The annual operational energy use for different energy sources was input based on the baseline calibrated energy model and recommended retrofit model. The system boundary option of A to C includes raw material supply, transport, manufacturing, transport, construction-installation process, repainting of surfaces for maintenance (excludes all other kinds of maintenance), replacement, operational energy use, deconstruction demolition, transport, disposal (facility equipment energy use and landfill 
site effects). A to D would also include the benefits and loads beyond the building life for example of steel recycling and carbon sequestration of wood products. The A to D boundary condition was chosen to consider the carbon sequestration of the existing wood structure of the building. The A to C boundary condition was chosen for calculating the embodied carbon of retrofit materials since the analysis period was only 20 years.

The bill of materials report generated by Athena's calculations shows the details of quantities of each material used for different components of the existing house (Figure 32). The program calculates amounts of nails and other building materials required for the size (dimensions of component are input by user) of specific components (e.g. walls). The LCA report only shows the total environmental impact for different metrics (global warming potential, fossil fuel consumption, etc.) for components of the house (walls, roofs, foundation, floors, beams, columns, and extra materials), not individual materials.

The bill of materials for the retrofit package is shown in Figure 33. It is assumed that a similar amount of piping and materials would be used for mechanical systems in a new house. Additionally, embodied carbon of building systems (e.g. HVAC, sanitary, sprinklers, elevators) was found to be quite low at around $2 \%$ of total embodied carbon of a building (Häkkinen, Kuittinen, Ruuska, \& Jung, 2015). Due to the assumed similar systems and insignificance of building systems in the total embodied carbon, it was not considered in the carbon analysis. The embodied carbon of daylight and appliance sensors and controls was not considered due to limitations in data available in embodied carbon tools and research.

To calculate the embodied energy saved by conserving most of the existing building, the lifespan of the existing materials was assumed to be 180 years since it is about 
131 years old (built in 1889) now and it is assumed to endure at least another 50 years. For the retrofit, a life span of 20 years and A to C lifecycle was used as the analysis period since this is an acceptable time until significant maintenance/repair/replacement is required. Other assumptions are shown in Table 11 below.

Table 11: Assumptions made for the existing building material inputs for Athena calculations

\begin{tabular}{|l|l|}
\hline Component & Assumption \\
\hline Roof insulation & $406 \mathrm{~mm}$ thickness \\
\hline $\begin{array}{l}\text { Wood shingles on roof of addition } \\
\text { of house }\end{array}$ & Type of wood assumed to be cedar siding \\
\hline Plaster and lath & $\begin{array}{l}\text { Used } 5 / 8 \text { " thickness of gypsum fibre board to represent existing } \\
\text { plaster and lath since it is not available in the software }\end{array}$ \\
\hline
\end{tabular}

Athena does not allow calculations without having a framing for the wall since it is designed for new construction calculations. However, for the retrofit, the wood studs and plywood in the wall framing will be conserved to reduce unnecessary waste so we would ignore the carbon from the framing in the total retrofit carbon. The carbon emissions and payback of the PV array was calculated separately from the envelope retrofit since it is not included in the Athena database. 


\begin{tabular}{|c|c|c|c|c|c|c|c|c|c|c|}
\hline Material & Unit & $\begin{array}{c}\text { Total } \\
\text { Quantity }\end{array}$ & $\begin{array}{c}\text { Columns \& } \\
\text { Beams }\end{array}$ & Floors & Foundations & Roofs & Walls & $\begin{array}{c}\text { Project Extra } \\
\text { Materials } \\
\end{array}$ & Mass Value & Mass Unit \\
\hline 1/2" Glass Mat Gypsum Panel & $\mathrm{m} 2$ & 418.0898 & 0.0000 & 268.3560 & 0.0000 & 80.6837 & 69.0501 & 0.0000 & 4.1377 & Tonnes \\
\hline 8" Normal Weight Concrete Block & Blocks & $1,694.4219$ & 0.0000 & 0.0000 & 0.0000 & 0.0000 & \begin{tabular}{|r|}
$1,694.421$ \\
9
\end{tabular} & 0.0000 & 30.0421 & Tonnes \\
\hline Ballast (aggregate stone) & $\mathrm{kg}$ & \begin{tabular}{r|}
$12,602.657$ \\
5 \\
\end{tabular} & 0.0000 & 0.0000 & 0.0000 & \begin{tabular}{|r|}
$12,602.65$ \\
75 \\
\end{tabular} & 0.0000 & 0.0000 & 12.6027 & Tonnes \\
\hline Cedar Wood Bevel Siding & $\mathrm{m} 2$ & 240.9541 & 0.0000 & 0.0000 & 0.0000 & 0.0000 & \begin{tabular}{|l|}
240.9541 \\
\end{tabular} & 0.0000 & 1.0192 & Tonnes \\
\hline Cold Rolled Sheet & Tonnes & 0.0744 & 0.0000 & 0.0000 & 0.0000 & 0.0000 & 0.0744 & 0.0000 & 0.0744 & Tonnes \\
\hline Concrete Benchmark CAN $25 \mathrm{MPa}$ & m3 & 8.9629 & 0.0000 & 0.0000 & 8.9629 & 0.0000 & 0.0000 & 0.0000 & 20.8784 & Tonnes \\
\hline Double Glazed No Coating Air & $\mathrm{m} 2$ & 172.6875 & 0.0000 & 0.0000 & 0.0000 & 0.0000 & 172.6875 & 0.0000 & 2.7964 & Tonnes \\
\hline FG Batt R11-15 & $\mathrm{m} 2(25 \mathrm{~mm})$ & 912.7683 & 0.0000 & 0.0000 & 0.0000 & 0.0000 & 912.7683 & 0.0000 & 0.2857 & Tonnes \\
\hline Mortar & m3 & 11.5075 & 0.0000 & 0.0000 & 0.0000 & 0.0000 & 11.5075 & 0.0000 & 21.7262 & Tonnes \\
\hline Nails & Tonnes & 0.1743 & 0.0000 & 0.0352 & 0.0000 & 0.0453 & 0.0938 & 0.0000 & 0.1743 & Tonnes \\
\hline Natural Stone & $\mathrm{m} 2$ & 135.5538 & 0.0000 & 0.0000 & 0.0000 & 0.0000 & \begin{tabular}{|l|}
135.5538 \\
\end{tabular} & 0.0000 & 10.2218 & Tonnes \\
\hline Ontario (Standard) Brick & $\mathrm{m} 2$ & 251.1943 & 0.0000 & 0.0000 & 0.0000 & 0.0000 & \begin{tabular}{|l|}
251.1943 \\
\end{tabular} & 0.0000 & 30.3945 & Tonnes \\
\hline Paper Tape & Tonnes & 0.0022 & 0.0000 & 0.0000 & 0.0000 & 0.0000 & 0.0022 & 0.0000 & 0.0022 & Tonnes \\
\hline
\end{tabular}

\begin{tabular}{|c|c|c|c|c|c|c|c|c|c|c|}
\hline Material & Unit & $\begin{array}{c}\text { Total } \\
\text { Quantity }\end{array}$ & $\begin{array}{c}\text { Columns \& } \\
\text { Beams }\end{array}$ & Floors & Foundations & Roofs & Walls & \begin{tabular}{|c|} 
Project Extra \\
Materials \\
\end{tabular} & Mass Value & Mass Unit \\
\hline Rebar, Rod, Light Sections & Tonnes & 0.2680 & 0.0000 & 0.0000 & 0.0000 & 0.0000 & 0.2680 & 0.0000 & 0.2680 & Tonnes \\
\hline Roofing Asphalt & $\mathrm{kg}$ & $5,156.8617$ & 0.0000 & 0.0000 & 0.0000 & \begin{tabular}{|r|}
$5,156.861$ \\
7
\end{tabular} & 0.0000 & 0.0000 & 5.1569 & Tonnes \\
\hline Screws Nuts \& Bolts & Tonnes & 0.0039 & 0.0000 & 0.0025 & 0.0000 & 0.0008 & 0.0006 & 0.0000 & 0.0039 & Tonnes \\
\hline Small Dimension Softwood Lumber, kiln-dried & $\mathrm{m} 3$ & 8.4587 & 0.0000 & 0.0000 & 0.0000 & 2.0492 & 6.4094 & 0.0000 & 3.5791 & Tonnes \\
\hline Softwood Plywood & m2 (9mm) & 843.4765 & 0.0000 & 323.5707 & 0.0000 & 97.2845 & 422.6213 & 0.0000 & 3.8321 & Tonnes \\
\hline Water Based Latex Paint & $\mathrm{L}$ & 177.3373 & 0.0000 & 0.0000 & 0.0000 & 0.0000 & 177.3373 & 0.0000 & 0.1330 & Tonnes \\
\hline Welded Wire Mesh / Ladder Wire & Tonnes & 0.0772 & 0.0000 & 0.0000 & 0.0772 & 0.0000 & 0.0000 & 0.0000 & 0.0772 & Tonnes \\
\hline
\end{tabular}

Figure 32: Bill of materials for existing house. 


\begin{tabular}{|c|c|c|c|c|c|c|c|c|c|c|}
\hline Material & Unit & $\begin{array}{c}\text { Total } \\
\text { Quantity }\end{array}$ & $\begin{array}{c}\text { Columns \& } \\
\text { Beams }\end{array}$ & Floors & Foundations & Roofs & Walls & $\begin{array}{c}\text { Project Extra } \\
\text { Materials }\end{array}$ & Mass Value & Mass Unit \\
\hline 1/2" Glass Mat Gypsum Panel & $\mathrm{m} 2$ & 196.0134 & 0.0000 & 0.0000 & 0.0000 & 0.0000 & 196.0134 & 0.0000 & 1.9399 & Tonnes \\
\hline Double Glazed No Coating Air & $\mathrm{m} 2$ & 13.9565 & 0.0000 & 0.0000 & 0.0000 & 0.0000 & 13.9565 & 0.0000 & 0.2260 & Tonnes \\
\hline Nails & Tonnes & 0.0390 & 0.0000 & 0.0000 & 0.0000 & 0.0000 & 0.0390 & 0.0000 & 0.0390 & Tonnes \\
\hline Polyiso Foam Board (unfaced) & m2 (25mm) & 921.4752 & 0.0000 & 0.0000 & 0.0000 & 0.0000 & 921.4752 & 0.0000 & 0.6901 & Tonnes \\
\hline Screws Nuts \& Bolts & Tonnes & 0.0018 & 0.0000 & 0.0000 & 0.0000 & 0.0000 & 0.0018 & 0.0000 & 0.0018 & Tonnes \\
\hline Water Based Latex Paint & $\mathrm{L}$ & 2.4584 & 0.0000 & 0.0000 & 0.0000 & 0.0000 & 2.4584 & 0.0000 & 0.0018 & Tonnes \\
\hline
\end{tabular}

Figure 33: Bill of materials for retrofits. 


\subsection{Results and Discussion}

\subsubsection{Carbon Emissions Calculations using Athena}

The annual operational global warming potential is $10,747 \mathrm{~kg} \mathrm{CO}_{2} \mathrm{eq}$, calculated from Athena's carbon intensities based on the house location in Ottawa. The avoided emissions of conserving the historic building would be $15,900 \mathrm{~kg} \mathrm{CO}_{2}$ eq for an assumed lifespan of 180 years ( 50 years of continued use in the future) and considering the carbon sequestration of wood components (Figure 34). About $400 \mathrm{~kg} \mathrm{CO}_{2}$ eq would be wasted from the plaster and lath and old insulation that would not be conserved during the retrofit. The retrofit would create about $2130 \mathrm{~kg} \mathrm{CO}$ eq of embodied carbon. The operational energy savings from the envelope, HVAC, lighting and appliance sensors and controls retrofit corresponds to about $135,870 \mathrm{~kg} \mathrm{CO}_{2}$ eq carbon emissions saved over 20 years of operation or $6793 \mathrm{~kg}$ $\mathrm{CO}_{2}$ eq annually (Figure 35). The carbon emissions of the envelope retrofit would be paid back within the first year after the retrofit is completed (see calculations in Appendix G for details). The carbon emissions saved from the retrofit over about 2.3 years of operation is already equal to the carbon emissions of the existing structure. 


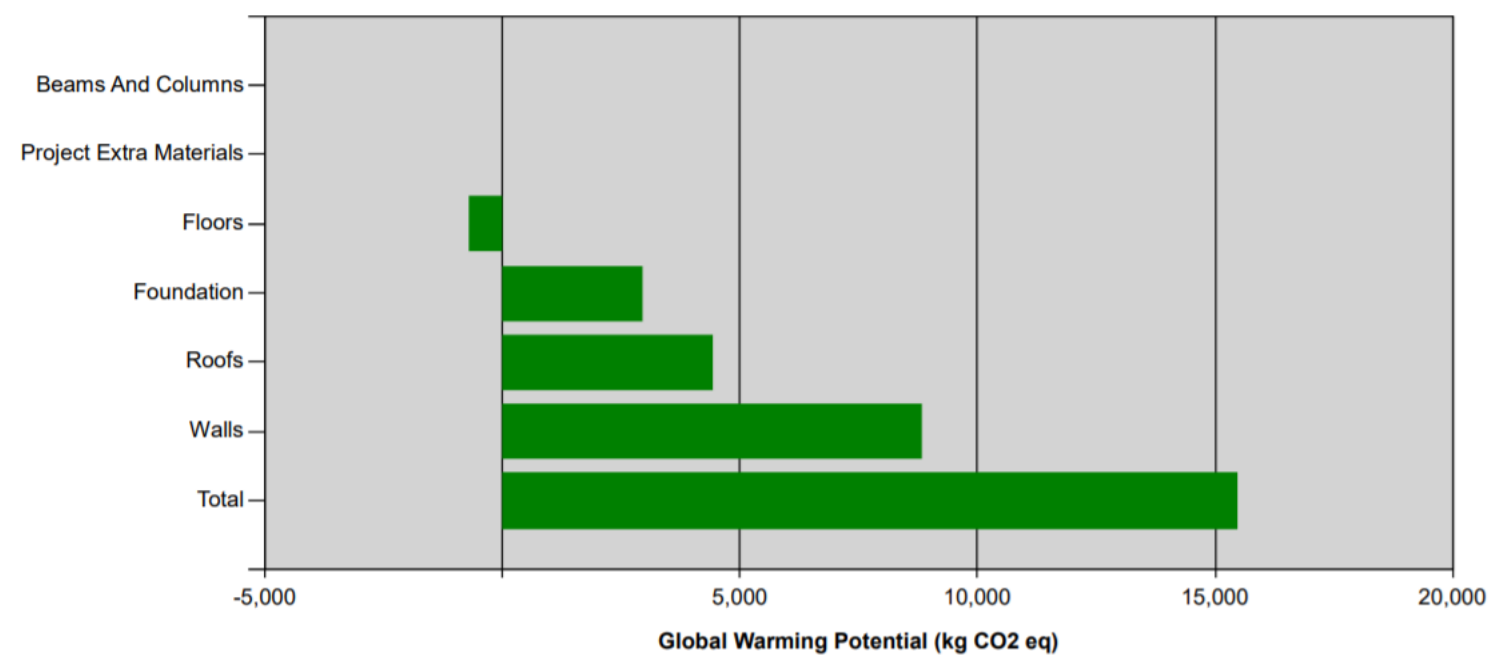

\begin{tabular}{|l|c|r|}
\hline \multicolumn{1}{|c|}{ Assembly Group } & Unit & \multicolumn{1}{c|}{ Total } \\
\hline Beams And Columns & $\mathrm{kg} \mathrm{CO} 2$ eq & $0.00 \mathrm{E}+00$ \\
\hline Floors & $\mathrm{kg} \mathrm{CO} 2 \mathrm{eq}$ & $-7.22 \mathrm{E}+02$ \\
\hline Foundation & $\mathrm{kg} \mathrm{CO} 2 \mathrm{eq}$ & $2.95 \mathrm{E}+03$ \\
\hline Project Extra Materials & $\mathrm{kg} \mathrm{CO} 2$ eq & $0.00 \mathrm{E}+00$ \\
\hline Roofs & $\mathrm{kg} \mathrm{CO} 2$ eq & $4.41 \mathrm{E}+03$ \\
\hline Walls & $\mathrm{kg} \mathrm{CO} 2$ eq & $8.83 \mathrm{E}+03$ \\
\hline Total & $\mathbf{k g ~ C O 2 ~ e q}$ & $\mathbf{1 . 5 5 E}+\mathbf{0 4}$ \\
\hline
\end{tabular}

Figure 34: Avoided carbon emissions of conserving most existing building components for a 180-year lifespan (A to D).

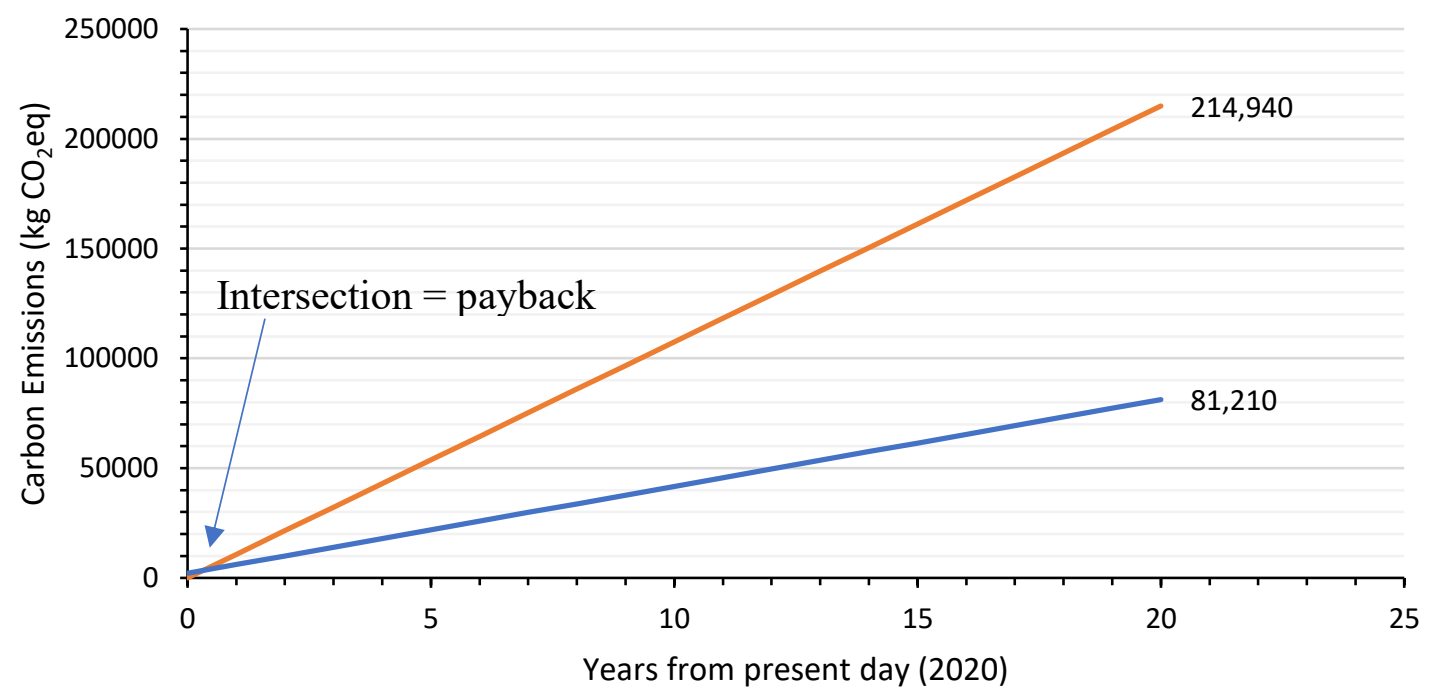

Existing, unretrofitted $\longrightarrow$ Retrofitted

Figure 35: Existing unretrofitted vs retrofitted embodied and operational carbon emissions 


\subsubsection{Solar PV Carbon Emissions}

Based on Bush, Jacques, Scott, \& Barrett, (2014) the embodied carbon intensity of solar PVs is about $100 \mathrm{~g} \mathrm{CO}_{2} \mathrm{eq} / \mathrm{kWh}$ output ${ }^{9}$. For the estimated output of $8608 \mathrm{kWh} / \mathrm{year}$, the embodied $\mathrm{CO}_{2}$ eq emissions are calculated to be about $860.8 \mathrm{~kg} \mathrm{CO}_{2}$ eq. The $8608 \mathrm{kWh} /$ year equates to $17,346 \mathrm{~kg} \mathrm{CO}_{2}$ eq of carbon emissions saved over 20 years from solar PV power generation ${ }^{10}$. The operational savings per year equates to about $867 \mathrm{~kg} \mathrm{CO}_{2}$ eq per year. Therefore, the embodied energy of the solar PV array is also paid back within the year. The total carbon savings, accounting for the savings from solar PV power generation, over 20 years is 150 tonnes $\mathrm{CO}_{2}$ eq (Figure 36).

For the type of existing construction, massing, and the relatively low embodied carbon retrofit, the embodied carbon becomes quite negligible over the lifespan of the building as it only comprises $1.9 \%$ over a 180 -year period of operation (includes PV solar embodied energy). Embodied carbon calculations become more important when selecting more environmentally friendly materials for specific retrofits or construction. In this case, it makes sense to conserve most of the existing structure because of the savings of 15.5 tonnes $\mathrm{CO}_{2}$ eq from reduced construction materials in the present, saving the associated direct damages to the environment and conserving the historic value of the building.

${ }^{9}$ Used Fig. 7 from Bush, Jacques, Scott, \& Barrett, (2014) of carbon intensities (g CO $\mathrm{CO}_{2}$ eq) vs $\mathrm{kWh} / \mathrm{m}^{2}$ average annual irradiance. Based on the average annual solar irradiance of the PV surfaces of about $2095 \mathrm{kWh} / \mathrm{m}^{2}$ (modelled using a TMY weather file), then the carbon intensity is estimated to be about $100 \mathrm{~g}$ $\mathrm{CO}_{2} \mathrm{eq} / \mathrm{kWh}$ output.

${ }^{10} \mathrm{PV}$ operational carbon savings were calculated comparing the difference in operational carbon emissions with and without PV solar panels in Athena (see Appendix G). 


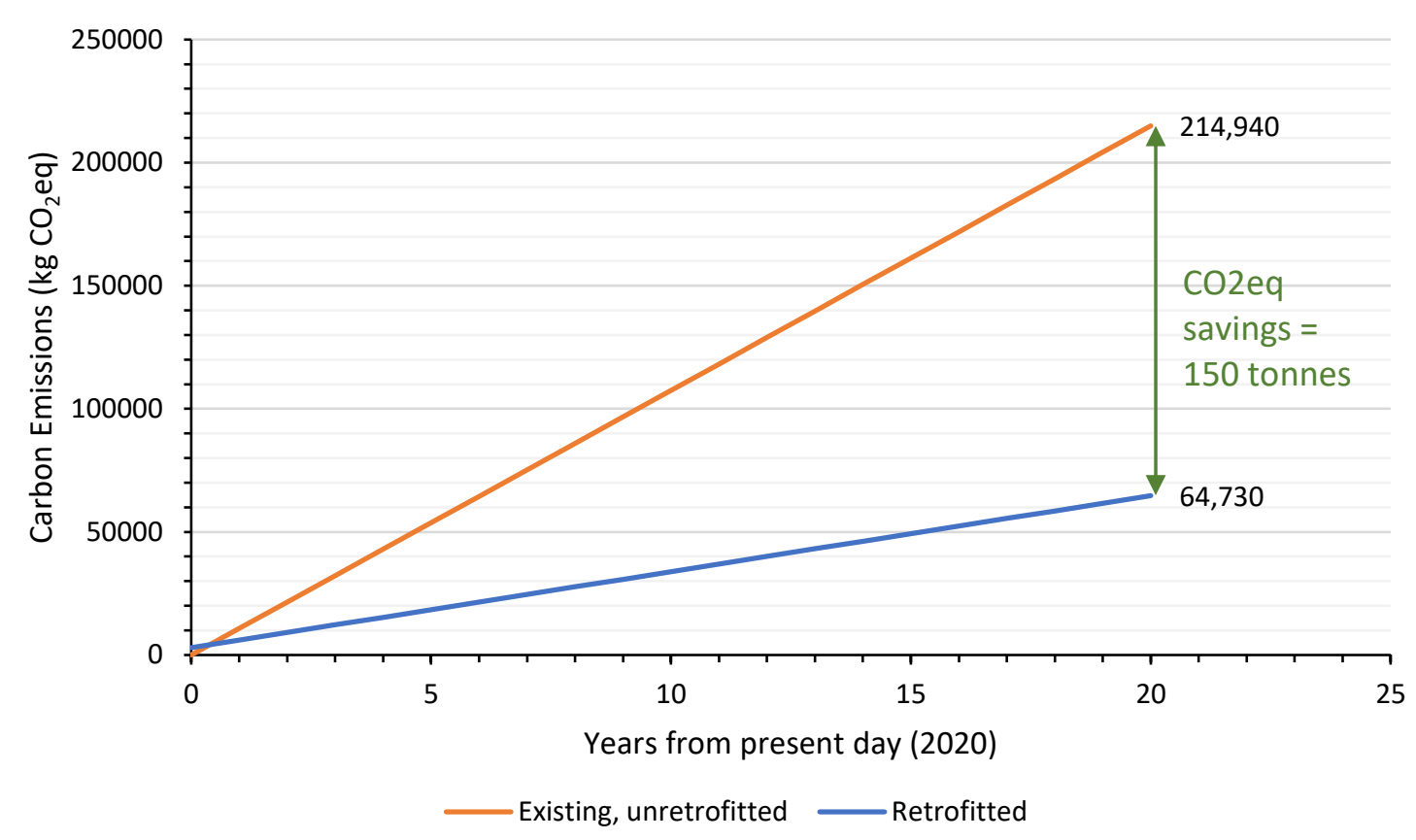

Figure 36: Existing unretrofitted vs retrofitted (including solar PV) embodied and operational carbon emissions. Total carbon savings from retrofit is 150 tonnes $\mathrm{CO}_{2}$ eq.

\subsection{Other Considerations}

The refrigerant in air-source heat pumps needs to be properly contained to avoid unwanted greenhouse gas emissions with a high GWP (global warming potential) of around 1370 to 2100 for commonly used refrigerants. Exploring the use of a lower GWP refrigerant, such as RHR-1 (mix of 75\% R152a and 25\% R32), can reduce the GWP to 279 and performs well in comparison to the other refrigerants (Kong, Zhang, \& Nie, 2018). However, this mixture is combustible whereas the commonly used refrigerants are not. The safety and viability of alternative refrigerants needs to be researched for cold climates. Athena does not account for destruction of vegetation, eco-system alteration and land disturbance (Athena Institute, 2019). The protection of the environment and natural land are important benefits of reusing as much materials of the existing building as possible. The embodied energy calculations may not show whether a material should be conserved based on a quick 
carbon payback, but the principles of conservation align well with environmental sustainability. If the element is in good condition, has heritage significance, and does not severely hinder the building performance, then it should be conserved. The embodied energy and carbon payback of a new house constructed to code was not compared to the existing building and retrofit scenarios, but this would be an interesting future analysis to complete.

\subsection{Conclusion}

In conclusion, the carbon payback of $2991 \mathrm{~kg} \mathrm{CO}_{2}$ eq associated with the retrofit package (including additional solar PV) would occur within the first year of operation after the retrofit. The annual carbon emissions from the operation of the house was reduced from $10,747 \mathrm{~kg} \mathrm{CO}_{2}$ eq to $3087 \mathrm{~kg} \mathrm{CO}_{2} \mathrm{eq}$, which is a $71 \%$ decrease. This demonstrates that the deep energy retrofit is beneficial to save 150 tonnes $\mathrm{CO}_{2}$ eq over 20 years of operation compared to the existing building operation. Conserving most of the existing structure which comprises $15,500 \mathrm{~kg} \mathrm{CO}_{2}$ eq of embodied energy is good heritage conservation and environmental sustainability practice. 


\section{Recommendations and Future Work}

Recommendations to further validate the research done for this thesis would be to focus on the implementation, monitoring, and maintenance step of the methodology, which was not in the scope of this thesis. This could entail updating the model and comparing it to measured energy data and submetering after retrofits are implemented. The energy analysis and cost analysis demonstrate that a full retrofit of the historic windows is not economically feasible, nor does it achieve a high amount of energy savings (4\%). The airtightness of rehabilitated heritage windows should be tested, since this is the main energy loss pathway compared to new window assemblies. As part of real-world validation, it would also be beneficial to demonstrate how a chimney can be well sealed to reduce heat loss and air leakage, while conserving this character defining element of a heritage house. Another element of the implementation phase that should be tested is how to best make use of historic radiators with new HVAC systems such as implementing a water heat pump system using historic decorated radiators. Conducting and integrating quantitative thermography into the process of creating a calibrated energy model is suggested as part of future work. Utilizing more non-invasive tools that do not require large amounts of data measured over long periods are good for reducing cost, the impact on the building, and improving the efficiency of the process of creating a calibrated energy model.

Informing the public about habits within their homes and offices that could reduce energy consumption to drive energy reductions is advised, since occupants are a significant variable in energy use predictions. The large-scale potential carbon reductions of changes 
in occupant behaviour and how to influence occupants to change may be pursued to help achieve additional carbon savings.

Detailed energy modelling should be made more easily adoptable by many people through workshops, improving software to be more user friendly, and possibly a certification process. This way the most appropriate energy retrofits for a specific building can be selected based on environmental and economic factors. The creation of the energy model involved simplifications in the geometry due to the software limitations. Improving energy modelling software so that complex geometry can be modelled and understood by the software without issues would advance the modelling process.

Additional policies to aid homeowners in implementing deep energy retrofits including on-site renewable energy for their homes will facilitate climate action within the residential sector. It is also important that homeowners of older houses are made aware of the potential heritage significance of certain elements, which when conserved, have environmental and social benefits.

The metrics used for calibration in this thesis were NMBE and CV(RMSE) for monthly data as outlined by ASHRAE guideline 14. An improved standard of calibration for energy models should be explored to enhance the quality of simulation predictions. Using other metrics such as the coefficient of variation and goodness of fit to determine the adequacy of the calibration may be investigated.

The carbon analysis in this thesis only looked at the carbon payback of the retrofit and savings compared to the existing building. Future work could involve comparing life cycle carbon emissions of various types of new buildings (with varying levels of energy 
consumption) compared to conserving an existing typology of heritage buildings such as the heritage house in this thesis.

The methodology of calibration used in this thesis was to conduct a one factor at a time sensitivity analysis on the initial energy model and use qualitative thermography and data from site surveys to inform the heuristic evidence-based calibration. The difficulty in applying Bayesian calibration to a complex heritage building model and how much it improves the energy predictions for the purpose of selecting measures to achieve a deep energy retrofit is a potential topic for further research. The methodology and decision framework presented in this thesis may be integrated into a software to facilitate the use of them for heritage conservation projects.

Finally, determining how to get better estimates from energy models, calculating uncertainty using a Monte Carlo analysis or other methods, and validating with real retrofits would improve the confidence in energy simulation results. Having this confidence will aid in appropriate decision-making by having accurate estimates of performance predictions. 


\section{Final Conclusions}

Trade-offs between heritage conservation and sustainability are necessary, since the IPCC findings indicate that carbon intensive existing buildings should be retrofitted. The total carbon emissions from the building stock need to be reduced by $81 \%$ and $99 \%$ by 2030 and 2050 to keep global warming below $1.5^{\circ} \mathrm{C}$. Heritage buildings embody cultural values that should be conserved for the social benefits. This presents a need to follow a methodology and decision framework for conducting deep energy retrofit analyses to achieve greater carbon reductions, while protecting significant values. While there are a handful of studies on energy retrofits and energy savings within heritage buildings, this thesis combines strategies from several methodologies to present a non-invasive methodology for creating a detailed calibrated energy model to simulate options in a systematic way. A decision framework is presented to help heritage and building professionals balance multiple objectives of energy and carbon reductions, occupant comfort, heritage values, and cost. The other contribution of this thesis was to provide a case study within a North American cold climate, where there have been limited studies done for energy retrofits of heritage buildings, which also considers occupant comfort and embodied carbon emissions.

The heritage house that was studied was built in 1889 in Ottawa, Canada. The heritage values are embedded within the Queen Anne Revival and Dutch Colonial architectural styles of the house. These values are identified by the historic red brick cladding, wooden double hung windows, large bay windows, stone foundation walls, and mansard roof. The house also has significant historical associations to James and William Hopper architects and current community leader and owner of the house, Angela Keller- 
Herzog. On the interior, the character defining elements are the decorated iron radiators, wood moulding and fireplace.

The methodology consisted of: an historical analysis; documentation/technical measurements/energy audit (architectural drawings, laser scanning, thermography); detailed energy model; sensitivity analysis; calibration of energy model based on evidence; viable retrofit options selected based on heritage impact assessment and other risk analyses; individual options analysis; recommending an appropriate package; and implementation, monitoring, maintenance and documentation of retrofits. Following this methodology and decision framework, the character defining elements were conserved, and $71 \%$ energy savings are predicted with the recommended retrofit package. This was achieved through: retrofits to the building envelope (reducing air infiltration, additional insulation, adding a vapour barrier, and repairing and rehabilitating windows); upgrade of HVAC system with a supplementary air-source heat pump while still making use of the radiators; additional solar PVs on-site; daylight sensors and controllers to reduce electrical lighting; and appliance sensors and controls to reduce unnecessary appliance energy use.

The cost analysis demonstrated that the high cost and low energy benefit of new storm windows, results in a payback period of 54 years. A 15-year payback period is achieved for the entire retrofit package when windows are simply repaired and additional solar PV panels are installed. The additional energy, carbon and cost savings of the PV panels reduced the payback period by 16 years (when compared to the same package and window retrofit option). The recommended retrofit package has a capital cost of $\$ 43,084$.

The carbon payback of the retrofit occurs within the first year because of its low embodied carbon of $2991 \mathrm{~kg} \mathrm{CO}_{2}$ eq. The retrofit package achieves a 71\% reduction in 87 
annual operational carbon emissions, saving 150 tonnes $\mathrm{CO}_{2}$ eq over 20 years of operation. Although the carbon payback may be quick for new retrofit elements, the payback period may be longer for a complete demolition and new construction, and other environmental impacts are not factored into the embodied carbon calculations. Considering the responsibility and values of heritage professionals and sustainability consultants, conserving the existing building has a positive social and overall sustainability impact.

This thesis presented a methodology and decision framework to balance the trade-offs between heritage conservation and sustainability for achieving deep energy and carbon savings within a heritage house in Ottawa. This approach can be applied to many residential or institutional/commercial heritage and existing buildings to realize a considerable amount of energy and associated carbon emissions reductions, to meet climate change mitigation objectives. 


\section{References}

Adhikari, R., Longo, E., Pracchi, V., Rogora, A., Rosina, E., \& Guilia, S. (2011). Methodological procedure for energy performance evaluation of historical buildings. Conference Proceedings of the 27th International Conference on Passive and Low Energy Architecture, Louvain-La-Neuve, Belgium. Presses Universitaires de Louvain.

Alev, Ü., Eskola, L., Arumägi, E., Jokisalo, J., Donarelli, A., Siren, K., ... Kalamees, T. (2014). Renovation alternatives to improve energy performance of historic rural houses in the Baltic Sea region. Energy and Buildings. https://doi.org/10.1016/j.enbuild.2014.03.049

Alongi, A., Scoccia, R., Motta, M., \& Mazzarella, L. (2015). Numerical investigation of the Castle of Zena energy needs and a feasibility study for the implementation of electric and gas driven heat pump. Energy and Buildings, 95, 32-38. https://doi.org/10.1016/j.enbuild.2014.11.012

Arumägi, E., \& Kalamees, T. (2014). Analysis of energy economic renovation for historic wooden apartment buildings in cold climates. Applied Energy. https://doi.org/10.1016/j.apenergy.2013.10.041

Ascione, F., de Rossi, F., \& Vanoli, G. P. (2011). Energy retrofit of historical buildings: theoretical and experimental investigations for the modelling of reliable performance scenarios. Energy and Buildings, 43(8), 1925-1936. https://doi.org/10.1016/J.ENBUILD.2011.03.040

ASHRAE. (2014). ASHRAE Guideline 14: Measurement of Energy, Demand, and Water Savings. American Society of Heating, Refrigeration and Air-Conditioning Engineers.

ASHRAE. (2017). ASHRAE Handbook-Fundamentals. American Society of Heating, Refrigeration and Air-Conditioning Engineers.

Athena Institute. (2019). User Manual and Transparency Document.

Belisle, R. (2017). Energy Efficiency Evaluation - 166 Glebe. Ottawa.

Ben, H., \& Steemers, K. (2014). Energy retrofit and occupant behaviour in protected housing: A case study of the Brunswick Centre in London. Energy and Buildings. https://doi.org/10.1016/j.enbuild.2014.05.019

Bertolin, C., \& Loli, A. (2018). Sustainable interventions in historic buildings: A developing decision making tool. Journal of Cultural Heritage, 34, 291-302. https://doi.org/10.1016/j.culher.2018.08.010

Bin, G., \& Parker, P. (2012). Measuring buildings for sustainability: Comparing the initial and retrofit ecological footprint of a century home - The REEP House. Applied Energy, 93, 24-32. https://doi.org/10.1016/j.apenergy.2011.05.055

Blaszak, K. M., \& Richman, R. (2013). Prioritizing Method for Retrofitting Toronto's Single-Family Housing Stock to Reduce Heating and Cooling Loads. Journal of 
Architectural Engineering, 19(4), 229-244. https://doi.org/10.1061/(asce)ae.19435568.0000102

Brennan Less, \& Jain Walker. (2014). A Meta-Analysis of Deep Energy Retrofit Performance in U.S.

Bullen, P. A., \& Love, P. E. D. (2011). Adaptive reuse of heritage buildings. Structural Survey. https://doi.org/10.1108/02630801111182439

Bush, R., Jacques, D. A., Scott, K., \& Barrett, J. (2014). The carbon payback of microgeneration: An integrated hybrid input-output approach. 85-98. https://doi.org/10.1016/j.apenergy.2013.12.063

CCBFC (Canadian Commission on Building and Fire Codes), NRC (National Research Council of Canada). (2015). National Energy Code of Canada for Buildings. Ottawa.

CANADIAN SOLAR CS6X-310P, 310 WATT POLY SOLAR PANEL. (2020). Retrieved from https://www.gogreensolar.com/products/canadian-solar-cs6x-310p-pt-310watt-poly-solar-panel

Carrie Armel, K., Gupta, A., Shrimali, G., \& Albert, A. (2013). Is disaggregation the holy grail of energy efficiency? The case of electricity. Energy Policy. https://doi.org/10.1016/j.enpol.2012.08.062

Chapman, R., Howden-Chapman, P., Viggers, H., O’Dea, D., \& Kennedy, M. (2009). Retrofitting houses with insulation: A cost-benefit analysis of a randomised community trial. Journal of Epidemiology and Community Health, 63(4), 271-277. https://doi.org/10.1136/jech.2007.070037

CIBSE. (2002). Guide to building services for historic buildings - sustainable services for traditional buildings. London.

City of Ottawa, (2019). Phase II: Clemow Estate Heritage Study: area analysis and recommendations. $1-51$.

Clemow Estate Phase II. (2016). Retrieved from Glebe Community Association website: https://glebeca.ca/clemow-estate-phase-ii/

Cost of Solar Power In Canada. (2019). Retrieved from https://energyhub.org/cost-solarpower-canada/\#system-costs

Debusk, S. (2012). New Low-e Glass or Window Film? A Comparison to Help You Decide. Retrieved from https://www.buildings.com/news/industrynews/articleid/14300/title/new-low-e-glass-or-window-film-a-comparison-to-helpyou-decide/viewall/true

Diamond, R. C. (2001). An overview of the u.s. building stock 1. (January), 1-17.

DOE (Department of Energy). (2011). Buildings energy data book. Washington, DC: U.S. Department of Energy, Office of Energy Efficiency and Renewable Energy.

DOE (Department of Energy). (2020). EnergyPlus Testing and Validation. Retrieved from 
https://energyplus.net/testing

Duffie, J., \& Beckman, W. (1991). Solar Engineering of Thermal Processes (2nd ed.). New York, NY: Wiley.

Ecological Building Network, Integral Group, \& Siegel \& Strain Architects. (2015). The Total Carbon Study.

Economidou, M., Atanasiu, B., Despret, C., Maio, J., Nolte, I., \& Rapf, O. (2011). Europe's buildings under the microscope - a country-by-country review of the energy performance of buildings. Brussels: Buildings Performance Institute Europe.

Elefante, C. (2017). Changing World, Evolving Value: A Historic Preservation Roadmap Toward 2050. https://doi.org/10.2307/26250094

Elliott, A. (2011). Who will speak for historic buildings in the Glebe? Glebe Report.

EnergyPlus. (2018). DOE (U.S. Department of Energy), Building Technologies Offices (BTO) and National Renewable Energy Laboratory (NREL).

EnergyPlus Version 8.9 Documentation Input Output Reference. (2018). U.S. Department of Energy.

EU-Parliament. Directive 2010/31/Eu of the European Parliament and of the Council on the Energy Performance of Buildings. , (2010).

Fennell, H. C., \& Haehnel, J. (2005). Setting airtightness standards. ASHRAE Journal, 47(9), 26-31.

Ferland, S. (2012). Energy Efficiency Evaluation - 166 Glebe. Ottawa, Canada.

Ferriss, L. (Goody C. (2019). Leveraging the Historic Built Environment to Meet CarbonReduction Targets. APT International Miami, 1-28.

Fifita, S., Handa, C., Mundaca, L., \& Forster, P. (2018). Special Report: Global Warming of 1.5C, Ch. 2 Mitigation pathways compatible with $1.5 \mathrm{C}$ in the context of sustainable development. Geneva, Switzerland: IPCC, Meteorological Organization.

Grimmer, A. E. (1995). The Secretary of the Interior's Standards for the Treatment of Historic Properties with Guidelines for Preserving, Rehabilitation, Restoring \& Reconstructing Historic Buildings. Washington, DC: National Park Service.

Grytli, E., Kvaerness, L., Rokseth, L., \& Ygre, K. (2014). The Impact of Energy Improvement Measures on Heritage Buildings. Journal of Architectural Conservation, 18(3), 89-106. https://doi.org/10.1080/13556207.2012.10785120

Häkkinen, T., Kuittinen, M., Ruuska, A., \& Jung, N. (2015). Reducing embodied carbon during the design process of buildings. Journal of Building Engineering, 4, 1-13. https://doi.org/10.1016/j.jobe.2015.06.005

Harrestrup, M., \& Svendsen, S. (2015). Full-scale test of an old heritage multi-storey building undergoing energy retrofitting with focus on internal insulation and moisture. Building and

Environment,

85 , 123-133. 
https://doi.org/10.1016/j.buildenv.2014.12.005

Historic England. (2016). Secondary Glazing for Windows. Energy Efficiency and Historic Buildings, 85 .

Home Stars Get a Quote. (2020). Retrieved from https://homestars.com/

ICOMOS. (2011). Guidance on Heritage Impact Assessments for Cultural World Heritage Properties.

ICOMOS. (2019). The Future of Our Pasts: Engaging cultural heritage in climate action, ICOMOS Climate Change and Heritage Working Group.

IEA Annex 61 Business and Technical Concepts for Deep Energy Retrofits of Public Buildings. (2017). Retrieved from https://iea-annex61.org/

Intrinsik Corp., (2016). Greenhouse Gas Emissions Associated With Various Methods Of Power Generation In Ontario. Retrieved from https://www.opg.com/darlingtonrefurbishment/Documents/IntrinsikReport_GHG_OntarioPower.pdf

Irving, B. (2019). Investing in Old Windows. Retrieved from https://www.thisoldhouse.com/ideas/investing-old-windows

Jermyn, D., \& Richman, R. (2016). A process for developing deep energy retrofit strategies for single-family housing typologies: Three Toronto case studies. Energy and Buildings, 116, 522-534. https://doi.org/10.1016/j.enbuild.2016.01.022

Kegel, M., Sunye, R., \& Tamasauskas, J. (2012). Life Cycle Cost Comparison and Optimisation of Different Heat Pump Systems in the Canadian Climate. Retrieved from http://esim.ca

Keller-Herzog, A. (2018a). Environmental Cost Data Log Sheet. Ottawa, Canada.

Keller-Herzog, A. (2018b). Interview: Sustainability retrofits done to historic house studied.

Kong, X., Zhang, Y., \& Nie, J. (2018). A new mixture refrigerant for space heating air source heat pump: Theoretical modelling and performance analysis. Applied Sciences (Switzerland), 8(4), 1-16. https://doi.org/10.3390/app8040622

Loli, A., \& Bertolin, C. (2018). Towards Zero-Emission Refurbishment of Historic Buildings: A Literature Review. Buildings, $8(2), \quad 22$. https://doi.org/10.3390/buildings8020022

Ma, Z., Cooper, P., Daly, D., \& Ledo, L. (2012). Existing building retrofits: Methodology and state-of-the-art. Energy \& Buildings, 55, 889-902. https://doi.org/10.1016/j.enbuild.2012.08.018

Mercier, C., \& Moorefield, L. (2011). Commercial Office Plug Load Savings Assessment Final Report on: Commercial Office Plug Load Field Monitoring and Assessment.

MMAH (Ministry of Municipal Affairs and Housing). (2016). Ontario Supplementary 
Standard SB-10 Energy Efficiency Requirements.

Moran, F., Blight, T., Natarajan, S., \& Shea, A. (2014). The use of Passive House Planning Package to reduce energy use and $\mathrm{CO} 2$ emissions in historic dwellings. Energy and Buildings, 75, 216-227. https://doi.org/10.1016/j.enbuild.2013.12.043

Morelli, M., Rønby, L., Mikkelsen, S. E., Minzari, M. G., Kildemoes, T., \& Tommerup, H. M. (2012). Energy retrofitting of a typical old Danish multi-family building to a "nearly-zero" energy building based on experiences from a test apartment. Energy and Buildings. https://doi.org/10.1016/j.enbuild.2012.07.046

NRCan (Natural Resrouces Canada). (2004). Heating and Cooling with a Heat Pump.

NRCan (Natural Resrouces Canada). (2015). Energy Efficiency in Buildings: Benchmarks and Best Practices for Acute and Extended Health Care Facilities: A Guide for Energy Managers and Finance Officers.

NRCan (Natural Resrouces Canada). (2016). Comprehensive Energy Use Database Query System. Retrieved December 19, 2019, from http://oee.nrcan.gc.ca/corporate/statistics/neud/dpa/data_e/query_system/querysyste m.cfm

OpenStudio. (2018). National Renewable Energy Laboratory (NREL), U.S. Department of Energy, ANL, LBNL, ORNL, and PNNL.

Palmer, J., Livingstone, M., \& Adams, A. (2017). What Does it Cost to Retrofit Homes? UK Government Department for Business, Energy \& Industrial Strategy.

Parks Canada. (2006). Writing Statements of Significance.

Parks Canada. (2010). Standards and Guidelines for the Conservation of Historic Places in Canada. https://doi.org/R62-343/2010E-PDF

PIR (polyisocyanurate) Boards. (2019). Retrieved from Insulation Shop Ltd website: https://www.insulationshop.co/pir_rigid_insulation_boards.html

Pracchi, V. (2014). Historic Buildings and Energy Efficiency. Policy \& Practice, 5(2), 210-225. https://doi.org/10.1179/1756750514Z.00000000052

PV Module Product Datasheet MAXPOWER CS6X-310| 315|320|325P. (2017). Guelph, Ontario, Canada: Canadian Solar Inc.

Roberti, F., Oberegger, U. F., \& Gasparella, A. (2015). Calibrating historic building energy models to hourly indoor air and surface temperatures: Methodology and case study. Energy and Buildings, 108, 236-243. https://doi.org/10.1016/j.enbuild.2015.09.010

Ruiz, G. R., \& Bandera, C. F. (2017). Validation of calibrated energy models: Common errors. Energies, 10(10). https://doi.org/10.3390/en10101587

Schulte, D. (2018). BETTER BUILDINGS FOR A LOW-CARBON FUTURE Report of the Standing Committee on Environment and Sustainable Development. Retrieved from 
Www.ourcommons.ca

Sedovic, W., \& Gotthelf, J. H. (2005). What Replacement Windows Can't Replace: The Real Cost of Removing Historic Windows. APT Bulletin: Journal of Preservation Technology, 36(4), 25-29.

Senate. (2018). Reducing Greenhouse Gas Emissions from Canada's Built Environment. Ottawa, Canada.

Sotes, J. (2019). A Clearer View on Ontario's Emissions: Electricity emissions factors and guidelines. In The Atmospheric Fund. Toronto, ON, Canada.

Straube, J., \& Schumacher, C. (2007). Interior Insulation Retrofits of Load-Bearing Masonry Walls in Cold Climates. Journal of Green Building, 2(2).

Troi, A. (2011). Historic buildings and city centres-the potential impact of conservation compatible energy refurbishment on climate protection and living conditions. Retrieved from http://www.buildup.eu/sites/default/files/2011_EM_Troi_Impact.pdf

United Nations. (2019). Sustainable Development Goal 11 - Make cities and human settlements. Retrieved from United Nations website: https://sustainabledevelopment.un.org/sdg11

University of Alaska Fairbanks. (2017). Permeability of Common Building Material to Water Vapor.

Urbandale Centre for Home Energy Research. (2017). Carleton University.

Van Balen, K. (2008). The Nara Grid: an evaluation scheme based on the Nara Document on Authenticity. APT Bulletin: Journal of Preservation Technology, 39(2-3), 39-45.

Walker, I. S., \& Wilson, D. J. (1998). Field validation of algebraic equations for stack and wind driven air infiltration calculations. ASHRAE Transactions, 104(2), 118.

Webb, A. L. (2017). Energy retrofits in historic and traditional buildings: A review of problems and methods. https://doi.org/10.1016/j.rser.2017.01.145

Window Replacement Cost Estimator. (2019). Retrieved from Ecoline Windows website: https://www.ecolinewindows.ca/pricing/

Wireless Lighting Controls: A Total Cost Analysis. (2016).

Young, R. A. (2012). Stewardship of the Built Environment: Sustainability, preservation, and reuse. https://doi.org/doi:10.5822/978-1-61091-236-5

Zhou, W. (2018). IPCC 2018, cap2. Global Warming of $1.5^{\circ}$ C. An IPCC Special Report. 


\section{Appendices}

A: Floor Plans used to create model geometry

Only first floor is provided as it gives an idea of massing and spaces in building (other floors are similar)

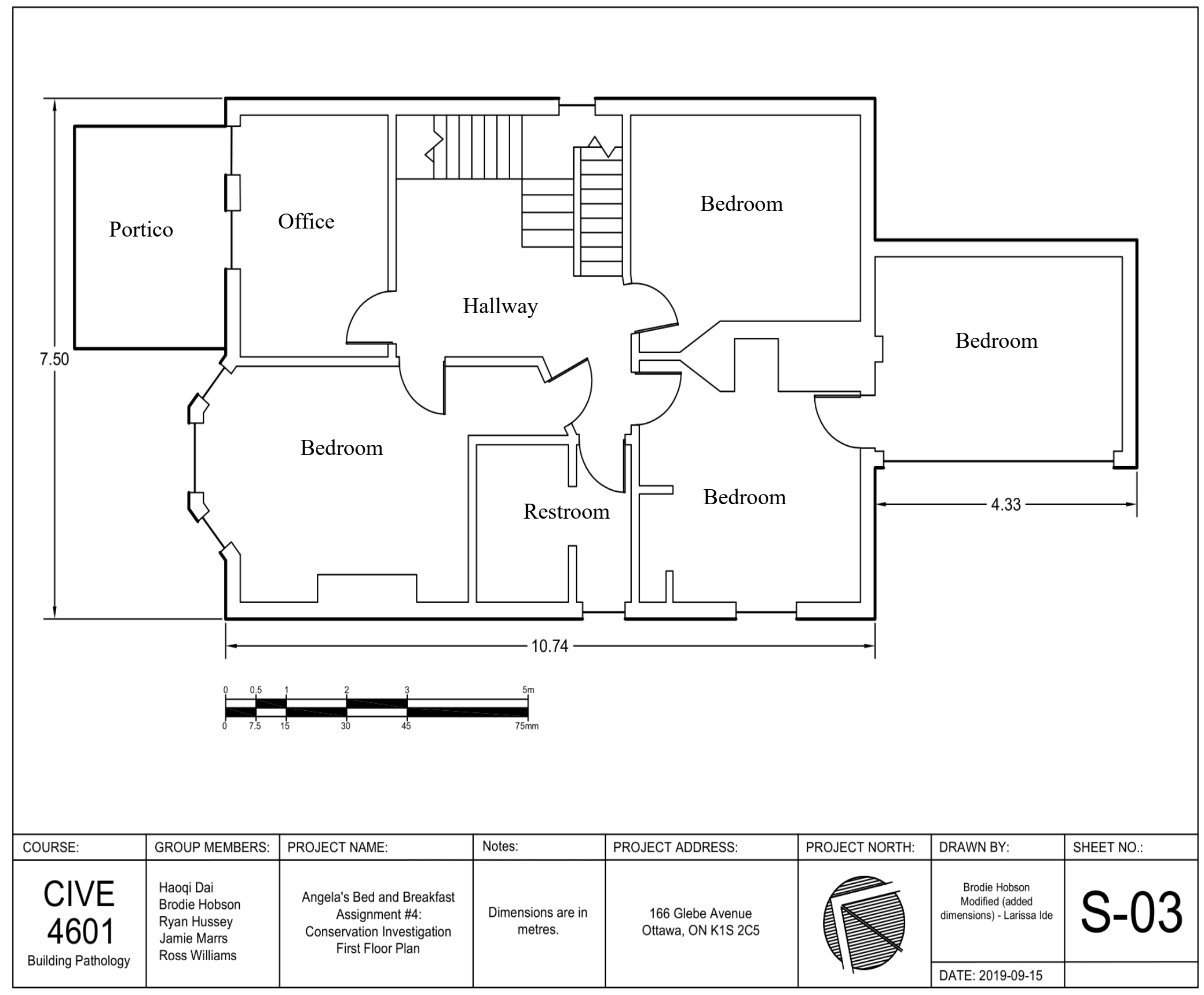




\section{B: Model Geometry and Model Details}

Different views of the final model

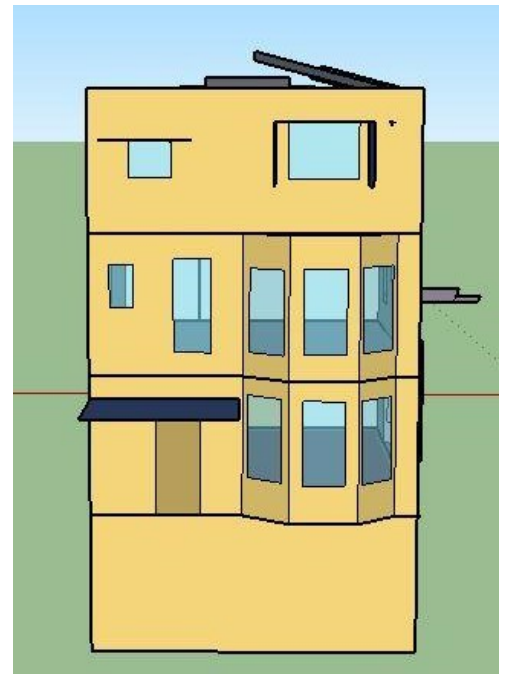

(a) North-West façade

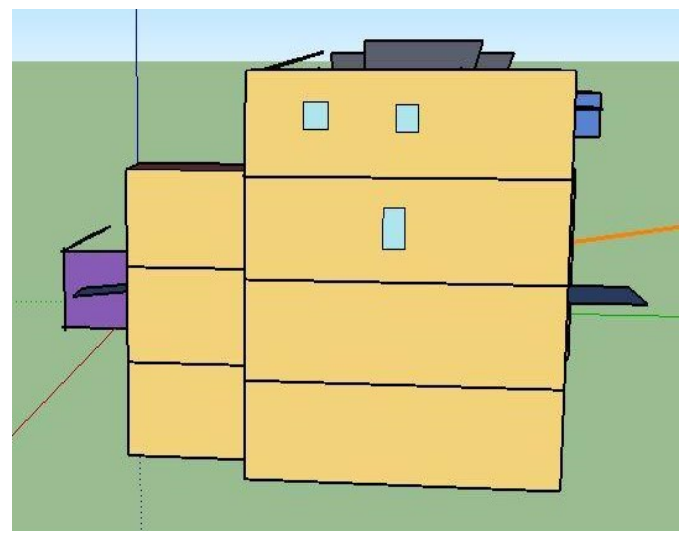

(c) North-East façade

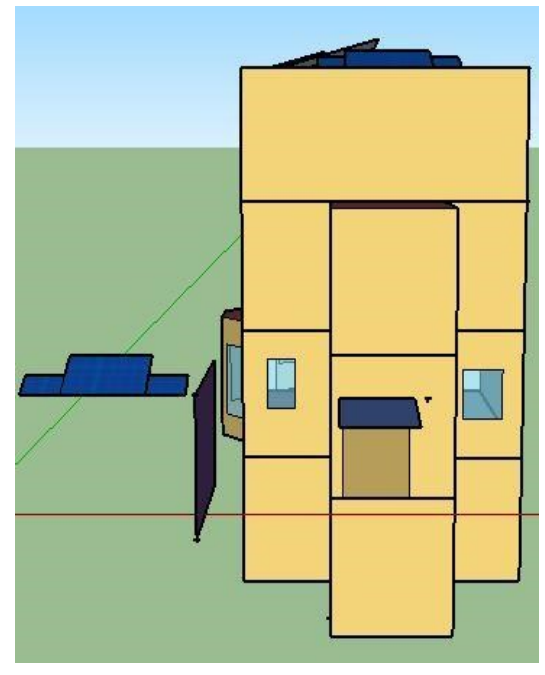

(b) South-East façade

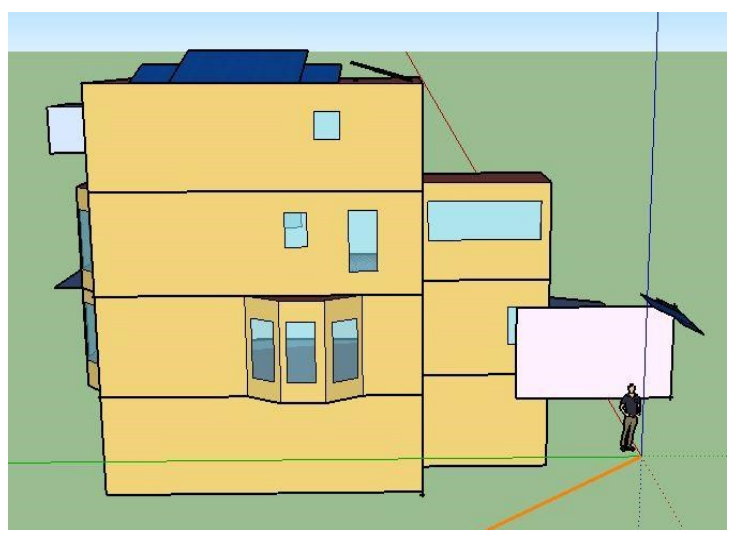

(d) South-West façade

Internal Gains:

People: Fraction radiant $=0.3$. Fraction convective $=0.7$.

Lighting was $2.56 \mathrm{~W} / \mathrm{m}^{2}$ or $2.40 \mathrm{~W} / \mathrm{m}^{2}$ (basement has a lower level of lighting) depending on the zone. Fraction radiant $=0.5$. Fraction convective $=0.5$.

Electrical equipment (appliances): $6.2 \mathrm{~W} / \mathrm{m}^{2}$ for all zones. Fraction latent $=0.1$. Fraction radiant $=0.2$. Fraction convective $=0.7$.

Total sum of internal loads $=8.6$ to $8.7 \mathrm{~W} / \mathrm{m}^{2}$ 


\section{C: Full Sensitivity Analysis Results}

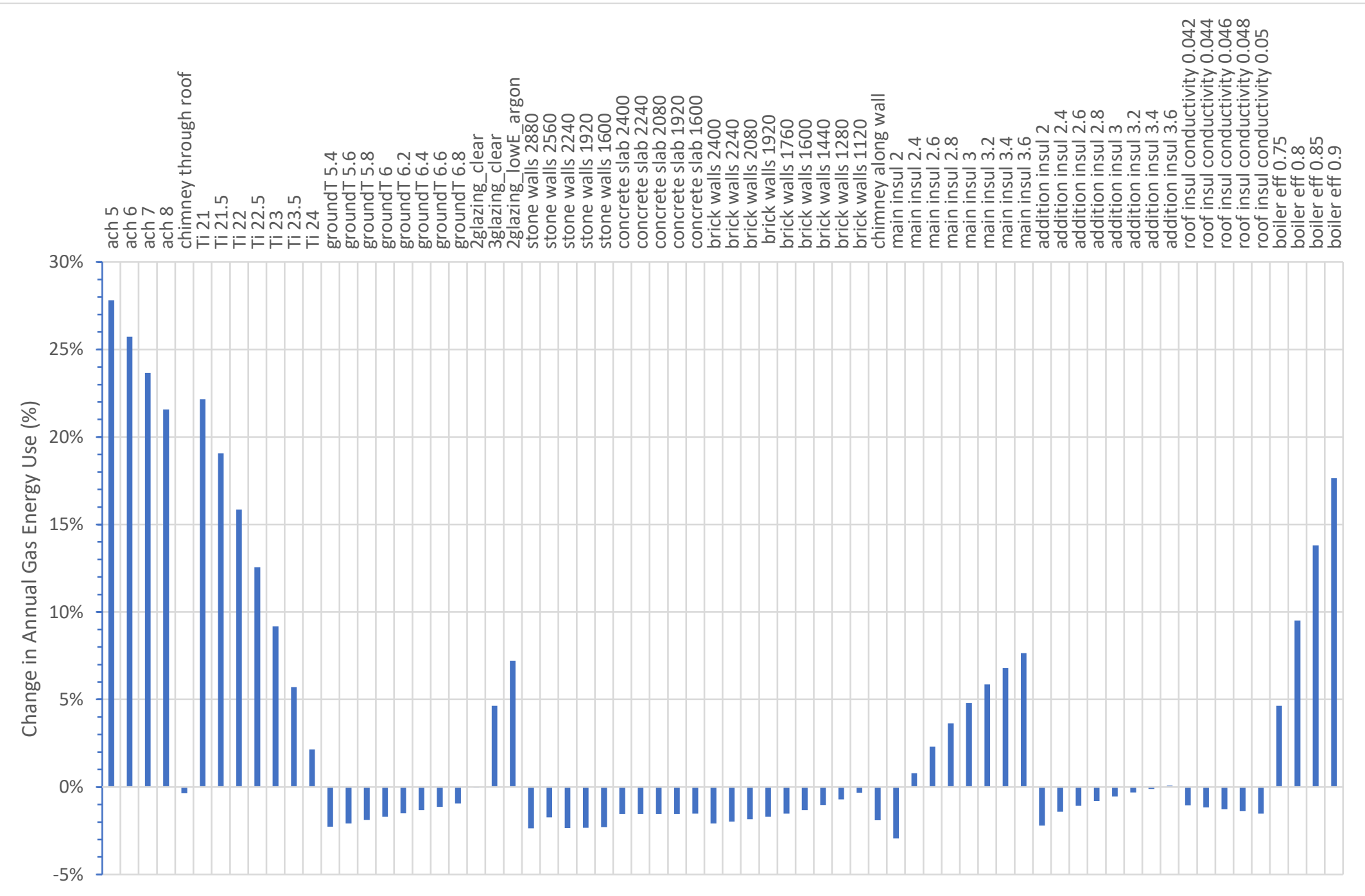




\section{D: Insulation Retrofit Scenarios}

\begin{tabular}{|l|l|}
\hline $\begin{array}{l}\text { Existing - Main House } \\
\text { Wall }\end{array}$ & $\begin{array}{l}\text { Thickness } \\
\text { (mm) }\end{array}$ \\
\hline Brick & 103 \\
\hline Air Cavity & 25 \\
\hline Wood sheathing & 25 \\
\hline Wood framing and batt & 100 \\
\hline Lath and plaster & 22.2 \\
\hline Total: & 275.2 \\
\hline $\begin{array}{l}\text { RSI based on model } \\
\text { calibration }\end{array}$ & 2.2 \\
\hline $\begin{array}{l}\text { Measurements in } \\
\text { Recap of combined } \\
\text { point clouds - main } \\
\text { house wall thickness }\end{array}$ & 282 \\
\hline $\begin{array}{l}\text { Measurements in } \\
\text { Recap of combined } \\
\text { point clouds - addition } \\
\text { of house wall thickness }\end{array}$ & 316 \\
\hline
\end{tabular}

\begin{tabular}{|c|c|c|c|c|c|}
\hline Rehabilitation 1 & $\begin{array}{l}\text { Thickness } \\
\text { (mm) }\end{array}$ & Rehabilitation 2 & $\begin{array}{l}\text { Thickness } \\
\text { (mm) }\end{array}$ & Rehabilitation 3 & $\begin{array}{l}\text { Thickness } \\
(\mathrm{mm})\end{array}$ \\
\hline Brick (old) & 103 & Brick (old) & 103 & Brick (old) & 103 \\
\hline Air Cavity & 25 & Air Cavity & 25 & Air Cavity & 25 \\
\hline Wood sheathing & 25 & Wood sheathing & 25 & Wood sheathing & 25 \\
\hline $\begin{array}{l}\text { Wood framing (old), } \\
\text { PIR }(50 \mathrm{~mm} \times 2)\end{array}$ & 100 & $\begin{array}{l}\text { Wood framing } \\
\text { (old), PIR ( } 50 \mathrm{~mm} \\
\text { x2) }\end{array}$ & 100 & $\begin{array}{l}\text { Wood framing } \\
\text { (old), PIR ( } 50 \mathrm{~mm} \\
\text { x2) }\end{array}$ & 100 \\
\hline PIR & 12 & PIR & 25 & PIR & 50 \\
\hline Gypsum board & 12.7 & Gypsum board & 12.7 & Gypsum board & 12.7 \\
\hline Total: & 277.7 & Total: & 290.7 & Total: & 315.7 \\
\hline $\begin{array}{l}\text { Increase from existing } \\
(\mathrm{mm})\end{array}$ & 2.5 & $\begin{array}{l}\text { Increase from } \\
\text { existing }(\mathrm{mm})\end{array}$ & 15.5 & $\begin{array}{l}\text { Increase from } \\
\text { existing (mm) }\end{array}$ & 40.5 \\
\hline $\begin{array}{l}\text { Total loss in area on } \\
\text { ground floor, level } 1 \\
\text { and level } 2\end{array}$ & $21 \mathrm{~cm}^{2}$ & $\begin{array}{l}\text { Total loss in area } \\
\text { on ground floor, } \\
\text { level } 1 \text { and level } 2\end{array}$ & $162 \mathrm{~cm}^{2}$ & $\begin{array}{l}\text { Total loss in area } \\
\text { on ground floor, } \\
\text { level } 1 \text { and level } \\
2\end{array}$ & $4.17 \mathrm{~m}^{2}$ \\
\hline $\begin{array}{l}\text { New RSI of wall } \\
\text { considering thermal } \\
\text { bridging of studs }\end{array}$ & 3.5 & $\begin{array}{l}\text { New RSI of wall } \\
\text { considering } \\
\text { thermal bridging } \\
\text { of studs }\end{array}$ & 4.1 & $\begin{array}{l}\text { New RSI of wall } \\
\text { considering } \\
\text { thermal bridging } \\
\text { of studs }\end{array}$ & 5.2 \\
\hline $\begin{array}{l}\text { RSI of insulation based } \\
\text { on model inputs (other } \\
\text { components are } 0.36 \\
\text { RSI in model) }\end{array}$ & 3.1 & $\begin{array}{l}\text { RSI of insulation } \\
\text { based on model } \\
\text { inputs (other } \\
\text { components are } \\
0.36 \text { RSI in model) }\end{array}$ & 3.7 & $\begin{array}{l}\text { RSI of insulation } \\
\text { based on model } \\
\text { inputs (other } \\
\text { components are } \\
0.36 \text { RSI in } \\
\text { model) }\end{array}$ & 4.8 \\
\hline
\end{tabular}




\begin{tabular}{|l|l|l|l|}
\hline Existing - Addition Wall & $\begin{array}{l}\text { Thickness } \\
(\mathbf{m m})\end{array}$ & Thermal conductivity (W/m-K) & $\begin{array}{l}\text { RSI = } \\
\text { deltaX/k }\end{array}$ \\
\hline Brick & 100 & 0.78 & 0.13 \\
\hline Air Cavity & 25 & -- & 0.17 \\
\hline Wood sheathing & 13 & 0.07 & 0.19 \\
\hline Studs & 152 & 0.15 & 1.01 \\
\hline Batt & 152 & 0.05 & 3.0 \\
\hline Wood framing and batt, Req & 152 & 0.05 & 2.4 \\
\hline Gypsum board & 12.7 & 0.16 & 0.08 \\
\hline Total & $\mathbf{3 0 3}$ & $\begin{array}{l}\text { Total RSI considering thermal } \\
\text { bridging of studs }\end{array}$ & $\mathbf{3 . 0}$ \\
\hline RSI of insulation based on model inputs (other components are 0.36 RSI in model) & 2.6 \\
\hline
\end{tabular}

\begin{tabular}{|l|l|l|l|}
\hline Addition wall - Rehab 1 & $\begin{array}{l}\text { Thickness } \\
(\mathbf{m m})\end{array}$ & Thermal conductivity (W/m-K) & $\begin{array}{l}\text { RSI = } \\
\text { deltaX/k }\end{array}$ \\
\hline Brick & 100 & 0.78 & 0.13 \\
\hline Air Cavity & 25 & -- & 0.17 \\
\hline Wood sheathing & 13 & 0.07 & 0.19 \\
\hline $\begin{array}{l}\text { Studs (assuming 6 in (152 } \\
\text { mm)) }\end{array}$ & 152 & 0.15 & 1.01 \\
\hline PIR & 152 & 0.022 & 6.91 \\
\hline Wood framing and batt, Req & 152 & 0.05 & 4.0 \\
\hline Gypsum board & 12.7 & 0.16 & 0.08 \\
\hline Total & $\mathbf{3 0 3}$ & $\begin{array}{l}\text { Total RSI considering thermal } \\
\text { bridging of studs }\end{array}$ & $\mathbf{4 . 6}$ \\
\hline RSI of insulation based on model inputs (other components are 0.36 RSI in model) & 4.2 \\
\hline
\end{tabular}

\begin{tabular}{|l|l|l|l|}
\hline Addition wall - Rehab 2 & $\begin{array}{l}\text { Thickness } \\
(\mathbf{m m})\end{array}$ & Thermal conductivity (W/m-K) & $\begin{array}{l}\text { RSI = } \\
\text { deltaX/k }\end{array}$ \\
\hline Brick & 100 & 0.78 & 0.13 \\
\hline Air Cavity & 25 & & 0.17 \\
\hline Wood sheathing & 13 & 0.07 & 0.19 \\
\hline $\begin{array}{l}\text { Studs (assuming 6 in (152 } \\
\text { mm)) }\end{array}$ & 152 & 0.15 & 1.0 \\
\hline PIR in stud space & 152 & 0.022 & 6.9 \\
\hline PIR2 & 12 & 0.022 & 0.55 \\
\hline Wood framing and batt, Req & 152 & 0.05 & 4.0 \\
\hline Gypsum board & 12.7 & 0.16 & 0.08 \\
\hline Total & $\mathbf{3 1 5}$ & $\begin{array}{l}\text { Total RSI considering thermal } \\
\text { bridging of studs }\end{array}$ & $\mathbf{5 . 1}$ \\
\hline RSI of insulation based on model inputs (other components are 0.36 RSI in model) & 4.7 \\
\hline
\end{tabular}




\begin{tabular}{|c|c|c|c|}
\hline $\begin{array}{l}\text { Basement Floor } \\
\text { - Existing }\end{array}$ & $\begin{array}{l}\text { Thickness } \\
(\mathbf{m m})\end{array}$ & $\begin{array}{l}\text { Thermal } \\
\text { conductivity } \\
\text { (W/m-K) }\end{array}$ & $\begin{array}{l}\text { RSI }= \\
\text { deltaX/k }\end{array}$ \\
\hline Concrete & 101.6 & 1.31 & 0.077 \\
\hline Carpet & & & 0.216 \\
\hline Total & 101.6 & & 0.29 \\
\hline \multicolumn{4}{|l|}{$\begin{array}{l}\text { Basement floor } \\
\text { rehab } 1\end{array}$} \\
\hline Carpet & -- & -- & 0.216 \\
\hline Wood floor & 25.4 & 0.121 & 0.210 \\
\hline PIR insulation & 50 & 0.022 & 2.27 \\
\hline Concrete & 101.6 & 1.31 & 0.077 \\
\hline Total & 177 & & 2.8 \\
\hline $\begin{array}{l}\text { Increase from } \\
\text { existing }\end{array}$ & 75 & & 2.5 \\
\hline \multicolumn{3}{|c|}{ RSI of insulation based on model inputs } & 2.1 \\
\hline \multicolumn{4}{|c|}{\begin{tabular}{l|l} 
Basement floor & \\
rehab 2 &
\end{tabular}} \\
\hline Carpet & -- & -- & 0.216 \\
\hline Wood floor & 25.4 & 0.121 & 0.210 \\
\hline PIR insulation & 100 & 0.022 & 4.55 \\
\hline Concrete & 101.6 & 1.31 & 0.077 \\
\hline Total & 227 & & 4.8 \\
\hline $\begin{array}{l}\text { Increase from } \\
\text { existing }\end{array}$ & 125 & & 4.5 \\
\hline \multicolumn{3}{|c|}{ RSI of insulation based on model inputs } & 4.1 \\
\hline \multicolumn{4}{|c|}{\begin{tabular}{l|l|l} 
Basement floor & \\
rehab 3 &
\end{tabular}} \\
\hline Carpet & -- & -- & 0.216 \\
\hline Wood floor & 25.4 & 0.121 & 0.210 \\
\hline PIR insulation & 150 & 0.022 & 6.82 \\
\hline Concrete & 101.6 & 1.31 & 0.077 \\
\hline Total & 277 & & 7.1 \\
\hline $\begin{array}{l}\text { Increase from } \\
\text { existing }\end{array}$ & 175 & & 6.8 \\
\hline \multicolumn{3}{|c|}{ RSI of insulation based on model inputs } & 6.4 \\
\hline
\end{tabular}




\section{E: PV Power Generation Calculations}

Site Information

\begin{tabular}{|l|l|l|l|l|}
\hline & Addition shingles & $\begin{array}{l}\text { Larger roof } \\
\text { space }\end{array}$ & Smaller roof space & $\begin{array}{l}\text { Overhang } \\
\text { above back } \\
\text { door }\end{array}$ \\
\hline $\begin{array}{l}\text { Available shingle } \\
\text { area (m } \mathbf{m}^{\mathbf{2}}\end{array}$ & 8.5 & 13.5 & 16.1 & 3.74 \\
\hline Panel tilt (degrees) & 83.2 & 66 & 12 & 5 \\
\hline Orientation & South & South & Northeast & South \\
\hline
\end{tabular}

Panel Information

\begin{tabular}{|l|l|}
\hline Manufacturer & Canadian Solar \\
\hline Model & Maxpower CS6X-310 \\
\hline $\begin{array}{l}\text { Nominal panel } \\
\text { power at STC }(\mathrm{W})\end{array}$ & 310 \\
\hline Panel area $\left(\mathrm{m}^{2}\right)$ & 1.92 \\
\hline Efficiency of panels & $16 \%$ \\
\hline
\end{tabular}

Other Assumptions

\begin{tabular}{|l|l|}
\hline $\begin{array}{l}\text { Miscellaneous array and power } \\
\text { conditioning losses }(\%)\end{array}$ & 5 \\
\hline Inverter efficiency $(\%)$ & 97 \\
\hline PV absorption rate $(\%)$ & 100 \\
\hline $\begin{array}{l}\text { Temperature coefficient for } \\
\text { module efficiency }\left(\% /{ }^{\circ} \mathrm{C}\right)\end{array}$ & 0.40 \\
\hline $\begin{array}{l}\text { Nominal operating cell } \\
\text { temperature }\left({ }^{\circ} \mathrm{C}\right)\end{array}$ & 45 \\
\hline Irradiance at STC $\left(\mathrm{W} / \mathrm{m}^{2}\right)$ & 1000 \\
\hline Reference temperature $\left({ }^{\circ} \mathrm{C}\right)$ & 25 \\
\hline
\end{tabular}

Solar Resource Ottawa

\begin{tabular}{|c|c|c|c|c|c|c|c|}
\hline \multirow[b]{2}{*}{ Month } & \multicolumn{2}{|c|}{$\begin{array}{l}\text { Daily solar radiation } \\
\text { (kWh/m2-day) }\end{array}$} & \multicolumn{4}{|c|}{ Daily solar radiation - tilted $\left(\mathrm{kWh} / \mathrm{m}^{2}\right.$-day) } & \multirow[b]{2}{*}{$\begin{array}{l}\text { Clearness } \\
\text { index (Duffie } \\
\text { \& Beckman, } \\
1991 \text { ) }\end{array}$} \\
\hline & $\begin{array}{l}\text { South } \\
\text { orientation }\end{array}$ & $\begin{array}{l}\text { NE roof } \\
\text { surface }\end{array}$ & $\begin{array}{l}\text { Addition } \\
\text { shingles }\end{array}$ & $\begin{array}{l}\text { Larger } \\
\text { roof } \\
\text { space }\end{array}$ & $\begin{array}{l}\text { Smaller } \\
\text { roof space }\end{array}$ & $\begin{array}{l}\text { Overhang } \\
\text { above } \\
\text { back door }\end{array}$ & \\
\hline Jan & 0.225 & 0.0409 & 0.226 & 8.49 & 0.076 & 0.235 & 0.48 \\
\hline Feb & 0.230 & 0.0751 & 0.230 & 8.66 & 0.140 & 0.240 & 0.54 \\
\hline Mar & 0.267 & 0.1225 & 0.267 & 10.1 & 0.228 & 0.278 & 0.55 \\
\hline Apr & 0.295 & 0.1854 & 0.295 & 11.1 & 0.346 & 0.307 & 0.51 \\
\hline May & 0.337 & 0.2173 & 0.337 & 12.6 & 0.405 & 0.351 & 0.51 \\
\hline Jun & 0.368 & 0.2272 & 0.369 & 13.8 & 0.423 & 0.384 & 0.51 \\
\hline Jul & 0.370 & 0.2267 & 0.370 & 13.9 & 0.422 & 0.386 & 0.53 \\
\hline Aug & 0.371 & 0.1870 & 0.372 & 14.0 & 0.348 & 0.387 & 0.51 \\
\hline Sep & 0.347 & 0.1339 & 0.348 & 13.1 & 0.250 & 0.362 & 0.48 \\
\hline Oct & 0.307 & 0.0746 & 0.307 & 11.5 & 0.139 & 0.320 & 0.44 \\
\hline Nov & 0.276 & 0.0392 & 0.277 & 10.4 & 0.073 & 0.288 & 0.36 \\
\hline Dec & 0.252 & 0.0305 & 0.252 & 9.49 & 0.057 & 0.263 & 0.41 \\
\hline
\end{tabular}




\begin{tabular}{|l|l|l|l|l|l|}
\hline & Addition shingles & Larger roof space & Smaller roof space & Overhang above back door & Total \\
\hline $\begin{array}{l}\text { Max panels at each } \\
\text { location }\end{array}$ & 4 & 7 & 8 & 1 & 20 \\
\hline Panel area $\left(\mathbf{m}^{\mathbf{2}}\right)$ & 7.68 & 13.44 & 15.36 & 1.92 \\
\hline
\end{tabular}

\section{Energy Output}

\begin{tabular}{|c|c|c|c|c|c|c|c|c|}
\hline & & & & & Monthly & tput (kV & & \\
\hline Month & $\begin{array}{l}\text { Mean monthly } \\
\text { ambient } \\
\text { temperature }\left({ }^{\circ} \mathrm{C}\right)\end{array}$ & $\operatorname{Tc}\left({ }^{\circ} \mathrm{C}\right)$ & $\begin{array}{l}\text { Days per } \\
\text { month }\end{array}$ & Avg monthly array efficiency $(\%)$ & $\begin{array}{l}\text { Addition } \\
\text { shingles }\end{array}$ & $\begin{array}{l}\text { Larger } \\
\text { roof } \\
\text { space }\end{array}$ & $\begin{array}{l}\text { Smaller } \\
\text { roof } \\
\text { space }\end{array}$ & $\begin{array}{l}\text { Overhang } \\
\text { above } \\
\text { back door }\end{array}$ \\
\hline Jan & -10.47 & 8.85 & 31 & $17.19 \%$ & 8.5 & 560 & 5.8 & 2.2 \\
\hline Feb & -8.39 & 12.49 & 28 & $16.95 \%$ & 7.7 & 509 & 9.4 & 2.0 \\
\hline Mar & -0.55 & 20.59 & 31 & $16.43 \%$ & 9.6 & 634 & 16.5 & 2.5 \\
\hline Apr & 6.42 & 26.52 & 30 & $16.05 \%$ & 10.1 & 662 & 23.5 & 2.6 \\
\hline May & 14.30 & 34.40 & 31 & $15.54 \%$ & 11.5 & 757 & 27.6 & 3.0 \\
\hline Jun & 19.30 & 39.41 & 30 & $15.22 \%$ & 11.9 & 785 & 27.4 & 3.1 \\
\hline Jul & 20.66 & 41.28 & 31 & $15.09 \%$ & 12.3 & 807 & 28.0 & 3.2 \\
\hline Aug & 20.17 & 40.28 & 31 & $15.16 \%$ & 12.4 & 814 & 23.2 & 3.2 \\
\hline Sep & 14.80 & 34.13 & 30 & $15.56 \%$ & 11.5 & 756 & 16.5 & 3.0 \\
\hline Oct & 8.47 & 26.75 & 31 & $16.03 \%$ & 10.8 & 711 & 9.8 & 2.8 \\
\hline Nov & 1.70 & 17.90 & 30 & $16.60 \%$ & 9.7 & 642 & 5.2 & 2.5 \\
\hline Dec & -4.54 & 12.96 & 31 & $16.92 \%$ & 9.4 & 617 & 4.2 & 2.4 \\
\hline & & & & Total output (kWh) & 8608 & & & \\
\hline & & & & Total output (kWh/m²) & 26 & & & \\
\hline & & & & $\begin{array}{l}\text { Total retrofit energy use after } \\
\text { considering PV generation (current and } \\
\text { new) }\end{array}$ & 44 & & & \\
\hline & & & & Total baseline including current PV & 149 & & & \\
\hline & & & & Total \% savings & $71 \%$ & & & \\
\hline
\end{tabular}




\section{F: Moisture Calculations}

\section{Winter Conditions}

\begin{tabular}{|l|l|}
\hline & Assumptions \\
\hline $\mathrm{T}_{\mathrm{i}}(\mathrm{C})$ & 21 \\
\hline & \\
& \\
$\mathrm{T}_{\mathrm{o}}(\mathrm{C})$ & -20 \\
\hline $\mathrm{RH}_{\mathrm{i}}$ & 0.35 \\
\hline $\mathrm{RH}_{\mathrm{o}}$ & 0.75 \\
\hline
\end{tabular}

$\mathrm{k}=$ thermal conductivity

\begin{tabular}{|l|l|l|l|}
\hline Materials & $\mathbf{x}(\mathbf{m})$ & $\mathbf{k}(\mathbf{W} / \mathbf{m k})$ & $\mathbf{m u}\left(\mathbf{n g} / \mathbf{P a - s - \mathbf { m } ^ { 2 } )}\right.$ \\
\hline gypsum & 0.0127 & 0.16 & 3760 \\
\hline $\begin{array}{l}\text { PIR insulation } \\
\text { enclosed in } \\
\text { aluminum foil to act } \\
\text { as a vapour barrier }\end{array}$ & 0.125 & 0.022 & 2.9 \\
\hline wood sheathing & 0.025 & 0.07 & 109 \\
\hline air & 0.025 & 0.15 & 7000 \\
\hline brick & 0.103 & 0.78 & 410 \\
\hline
\end{tabular}

$\mathrm{mu}=$ permeance

$\mathrm{R}$, thermal resistance $=\mathrm{x} / \mathrm{k}$

$R_{w}$, vapour resistance $=1 / \mathrm{mu}$

$\mathrm{p}_{\mathrm{w}}=$ vapour pressure

$\mathrm{p}_{\mathrm{sw}}=$ saturated vapour pressure

$q=$ heat flux

$\mathrm{q}_{\mathrm{w}}=$ vapour flux

$\mathrm{T}_{\mathrm{dp}}=$ dew point temperature

\begin{tabular}{|l|l|}
\hline $\mathrm{p}_{\mathrm{sw}, \mathrm{i}}(\mathrm{Pa})$ & 2479 \\
\hline $\begin{array}{l}\mathrm{p}_{\mathrm{sw}, \mathrm{o}}=\exp (16.65- \\
4030 /(\mathrm{T}(\mathrm{C})+235)) * 1000(\mathrm{~Pa})\end{array}$ & 123.2 \\
\hline $\mathrm{p}_{\mathrm{w}, \mathrm{i}}(\mathrm{Pa})$ & 867.6 \\
\hline $\mathrm{p}_{\mathrm{w}, \mathrm{o}}=\mathrm{p}_{\mathrm{sw}, \mathrm{o}} * \mathrm{RHo}(\mathrm{Pa})$ & 92.4 \\
\hline $\mathrm{q}=\left(\mathrm{T}_{\mathrm{i}}-\mathrm{T}_{\mathrm{o}}\right) / \mathrm{R}$ total $\left(\mathrm{W} / \mathrm{m}^{2}\right)$ & 10.1 \\
\hline $\mathrm{q}_{\mathrm{w}}=\left(\mathrm{p}_{\mathrm{wi}}-\mathrm{p}_{\mathrm{wo}}\right) / \mathrm{R}_{\mathrm{w} \_}$total $\left(\mathrm{ng} / \mathrm{s}-\mathrm{m}^{2}\right)$ & $2.14 \mathrm{E}+03$ \\
\hline
\end{tabular}




\begin{tabular}{|l|l|l|l|l|}
\hline & $\mathbf{R}\left(\mathbf{m}^{2}-\mathbf{K} / \mathbf{W}\right)$ & Source & $\begin{array}{l}\mathbf{R}_{\mathbf{w}}(\mathbf{P a}-\mathbf{s}- \\
\left.\mathbf{m}^{2} / \mathbf{n g}\right)\end{array}$ & Source \\
\hline indoor film & 0.100 & assumed & - & \\
\hline gypsum & 0.079 & (ASHRAE 2017) & 0.000266 & (ASHRAE 2017) \\
\hline $\begin{array}{l}\text { PIR insulation } \\
\text { wood } \\
\text { sheathing }\end{array}$ & 3.20 & (ASHRAE 2017) & 0.350 & $\begin{array}{l}\text { (University of Alaska } \\
\text { Fairbanks, 2017) }\end{array}$ \\
\hline air & 0.36 & (ASHRAE 2017) & 0.00920 & $\begin{array}{l}\text { (University of Alaska } \\
\text { Fairbanks, 2017) }\end{array}$ \\
\hline brick & 0.17 & (ASHRAE 2017) & 0.000143 & (ASHRAE 2017) \\
\hline outdoor film & 0.132 & (ASHRAE 2017) & 0.00244 & (ASHRAE 2017) \\
\hline Total & 0.040 & assumed & - & \\
\hline
\end{tabular}

\begin{tabular}{|l|l|l|l|l|}
\hline Interfaces & $\mathbf{P}_{\mathbf{w}} \mathbf{( P a )}$ & $\mathbf{T}_{\mathbf{d p}}(\mathbf{C})$ & $\mathbf{P}_{\text {sw }}(\mathbf{P a})$ & $\mathbf{R H}$ \\
\hline gypsum & 867.6 & 20.0 & 2329.6 & $37 \%$ \\
\hline gypsum_PIR & 867.0 & 19.2 & 2216.8 & $39 \%$ \\
\hline PIR_woodsheating & 117.6 & -13.0 & 222.4 & $53 \%$ \\
\hline woodsheathing_air & 97.9 & -16.6 & 165.0 & $59 \%$ \\
\hline air_brick & 97.6 & -18.3 & 143.1 & $68 \%$ \\
\hline brick & 92.4 & -19.6 & 127.6 & $\mathbf{7 2 \%}$ \\
\hline outdoors & 92.4 & -20.0 & 123.2 & $75 \%$ \\
\hline
\end{tabular}




\section{G: Carbon Calculations}

Note: Athena was used to calculate the $\mathrm{CO}_{2}$ eq embodied carbon for stage $\mathrm{A}$ to $\mathrm{C}$ (excludes end of life) of the wood studs and plywood in the walls which was calculated to be 1340 $\mathrm{kg} \mathrm{CO}$ eq. The total mass of the wood used in the house walls was calculated to be 3019 $\mathrm{kg}$ wood using dimensions input into Athena. This confirms an acceptable value for the carbon intensity of wood to be about $0.44 \mathrm{~kg} \mathrm{CO} 2 \mathrm{eq} / \mathrm{kg}$ of wood.

$1340 \mathrm{~kg} \mathrm{CO} 2 \mathrm{eq} / 3019 \mathrm{~kg}$ wood $=0.44 \mathrm{~kg} \mathrm{CO} \mathrm{CO}_{2} \mathrm{eq} / \mathrm{kg}$ of wood

Embodied GWP saved by conserving existing building in its entirety (A to D), 180 years $=15,900 \mathrm{~kg} \mathrm{CO} 2 \mathrm{eq}$

Avoided embodied GWP by conserving existing elements (A to D), 180 years $=15,500 \mathrm{~kg}$ $\mathrm{CO}_{2} \mathrm{eq}$

Materials wasted from existing building $=15,900-15,500=400 \mathrm{~kg} \mathrm{CO}_{2} \mathrm{eq}$

Avoided embodied GWP by conserving existing structure and elements (A to C), 180 years $=41,900 \mathrm{~kg} \mathrm{CO}$ eq (Figure 37)

Embodied GWP for retrofit (A to C), includes wood studs and plywood, 20 years $=3470$ $\mathrm{kg} \mathrm{CO}$ eq (Figure 38)

Operational GWP after retrofit over 20 years $=79,070 \mathrm{~kg} \mathrm{CO} 2 \mathrm{eq}$

$79,070 / 20=3954 \mathrm{~kg} \mathrm{CO}$ eq annually

Embodied GWP for retrofit (A to C) $=3470 \mathrm{~kg} \mathrm{CO}_{2} \mathrm{eq}-1340 \mathrm{~kg} \mathrm{CO}_{2}$ eq wood studs and plywood

$$
=2130 \mathrm{~kg} \mathrm{CO}{ }_{2} \mathrm{eq}
$$

Operational GWP no retrofit over 20 years $=214,939 \mathrm{~kg} \mathrm{CO}_{2} \mathrm{eq}$

$$
214,939 / 20=10,747 \mathrm{~kg} \mathrm{CO} 2 \text { eq annually }
$$


Operational Carbon Savings = Operational GWP no retrofit - Operational GWP after retrofit

$$
\begin{aligned}
& =214,939-79,070 \\
& =135,869 \mathrm{~kg} \mathrm{CO} 2 \text { eq saved over } 20 \text { years } \\
& =135,869 / 20 \\
& =6793 \mathrm{~kg} \mathrm{CO} \text { eq saved annually }
\end{aligned}
$$

\% Embodied Energy over 180-year lifespan of retrofitted building $=($ avoided $\mathrm{EE}$ emissions 20 years $(\mathrm{A}$ to $\mathrm{C})+$ retrofit $\mathrm{EE}(\mathrm{A}$ to $\mathrm{C})) /($ total $\mathrm{EE}+$ op. E 180 years) $* 100 \%$

$$
\begin{aligned}
& =(30,400+2130) /(30,400+2130+79,070+214,939 * 7.5) * 100 \% \\
& =1.9 \%
\end{aligned}
$$

PV carbon emissions saved from operation $=$ Operational GWP without PVs - Operational GWP with PVs

$$
=79,070-65,657 \mathrm{~kg} \mathrm{CO}_{2} \mathrm{eq}
$$

$=13,413 \mathrm{~kg} \mathrm{CO}$ eq saved over 20 years of operation 


\section{Carbon Payback without Additional PV Generation}

\begin{tabular}{|c|c|c|}
\hline Year & Existing, unrenovated & Existing, renovated \\
\hline $\begin{array}{l}0 \\
\text { (Present) }\end{array}$ & $\begin{array}{l}y=10747 x+0 \text { (no } \\
\text { additional embodied } \\
\text { carbon in present day) }\end{array}$ & $y=3954 x+2130$ \\
\hline 0 & 0 & 2130 \\
\hline 1 & 10747 & 6084 \\
\hline 2 & 21494 & 10038 \\
\hline 3 & 32241 & 13992 \\
\hline 4 & 42988 & 17946 \\
\hline 5 & 53735 & 21900 \\
\hline 6 & 64482 & 25854 \\
\hline 7 & 75229 & 29808 \\
\hline 8 & 85976 & 33762 \\
\hline 9 & 96723 & 37716 \\
\hline 10 & 107470 & 41670 \\
\hline 11 & 118217 & 45624 \\
\hline 12 & 128964 & 49578 \\
\hline 13 & 139711 & 53532 \\
\hline 14 & 150458 & 57486 \\
\hline 15 & 161205 & 61440 \\
\hline 16 & 171952 & 65394 \\
\hline 17 & 182699 & 69348 \\
\hline 18 & 193446 & 73302 \\
\hline 19 & 204193 & 77256 \\
\hline 20 & 214940 & 81210 \\
\hline
\end{tabular}

Total savings over 20 years $=133,730 \mathrm{~kg} \mathrm{CO} \mathrm{CO}_{2}=6,686.50 \mathrm{~kg} \mathrm{CO} \mathrm{C}_{2} \mathrm{eq}$ annually 


\section{Carbon Payback with Additional PV Generation}

\begin{tabular}{|l|l|l|}
\hline Year & Existing, unrenovated & Existing, renovated incl. PV \\
\hline $\begin{array}{l}0 \\
\text { (Present) }\end{array}$ & $\begin{array}{l}\text { y=10747x }+0 \text { (no } \\
\text { additional embodied } \\
\text { carbon in present day) }\end{array}$ & $\mathrm{y}=(3954-867) \mathrm{x}+2130+860.8$ \\
\hline 0 & 0 & 2991 \\
\hline 1 & 10747 & 6078 \\
\hline 2 & 21494 & 9165 \\
\hline 3 & 32241 & 12252 \\
\hline 4 & 42988 & 15339 \\
\hline 5 & 53735 & 18426 \\
\hline 6 & 64482 & 21513 \\
\hline 7 & 75229 & 24600 \\
\hline 8 & 85976 & 27687 \\
\hline 9 & 96723 & 30774 \\
\hline 10 & 107470 & 33861 \\
\hline 11 & 118217 & 36948 \\
\hline 12 & 128964 & 40035 \\
\hline 13 & 139711 & 43122 \\
\hline 14 & 150458 & 46209 \\
\hline 15 & 161205 & 49296 \\
\hline 16 & 171952 & 52383 \\
\hline 17 & 182699 & 55470 \\
\hline 18 & 193446 & 58557 \\
\hline 19 & 204193 & 61644 \\
\hline 20 & 214940 & 64731 \\
\hline & & \\
\hline & & \\
\hline
\end{tabular}

Total savings over 20 years $=150,209 \mathrm{~kg} \mathrm{CO} 2 \mathrm{eq}=7,510 \mathrm{~kg} \mathrm{CO}_{2} \mathrm{eq}$ annually 


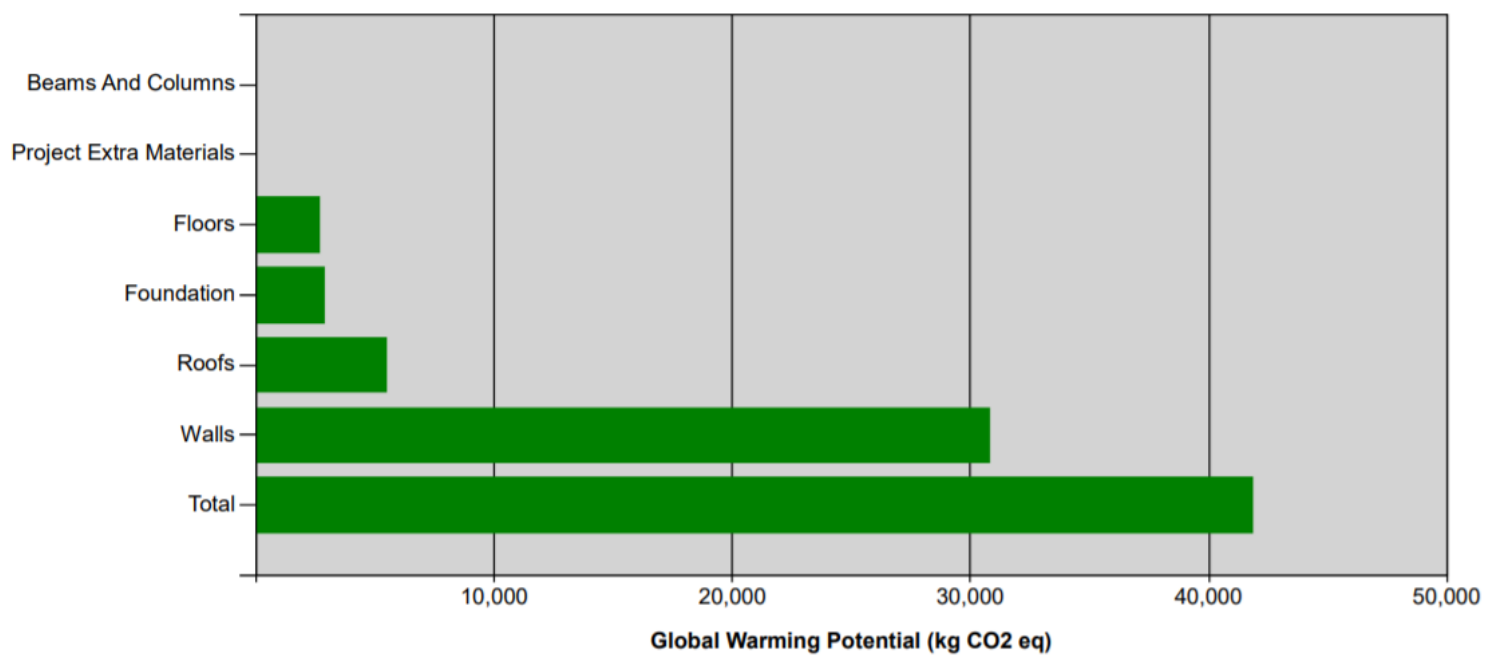

\begin{tabular}{|l|c|r|}
\hline \multicolumn{1}{|c|}{ Assembly Group } & Unit & \multicolumn{1}{c|}{ Total } \\
\hline Beams And Columns & $\mathrm{kg} \mathrm{CO} 2$ eq & $0.00 \mathrm{E}+00$ \\
\hline Floors & $\mathrm{kg} \mathrm{CO} 2$ eq & $2.67 \mathrm{E}+03$ \\
\hline Foundation & $\mathrm{kg} \mathrm{CO} 2$ eq & $2.91 \mathrm{E}+03$ \\
\hline Project Extra Materials & $\mathrm{kg} \mathrm{CO} 2$ eq & $0.00 \mathrm{E}+00$ \\
\hline Roofs & $\mathrm{kg} \mathrm{CO} 2$ eq & $5.49 \mathrm{E}+03$ \\
\hline Walls & $\mathrm{kg} \mathrm{CO} 2$ eq & $3.08 \mathrm{E}+04$ \\
\hline Total & $\mathbf{k g ~ C O 2 ~ e q}$ & $\mathbf{4 . 1 9 E}+\mathbf{0 4}$ \\
\hline
\end{tabular}

Figure 37: Existing building embodied energy, 180 years, $A$ to $C$ 


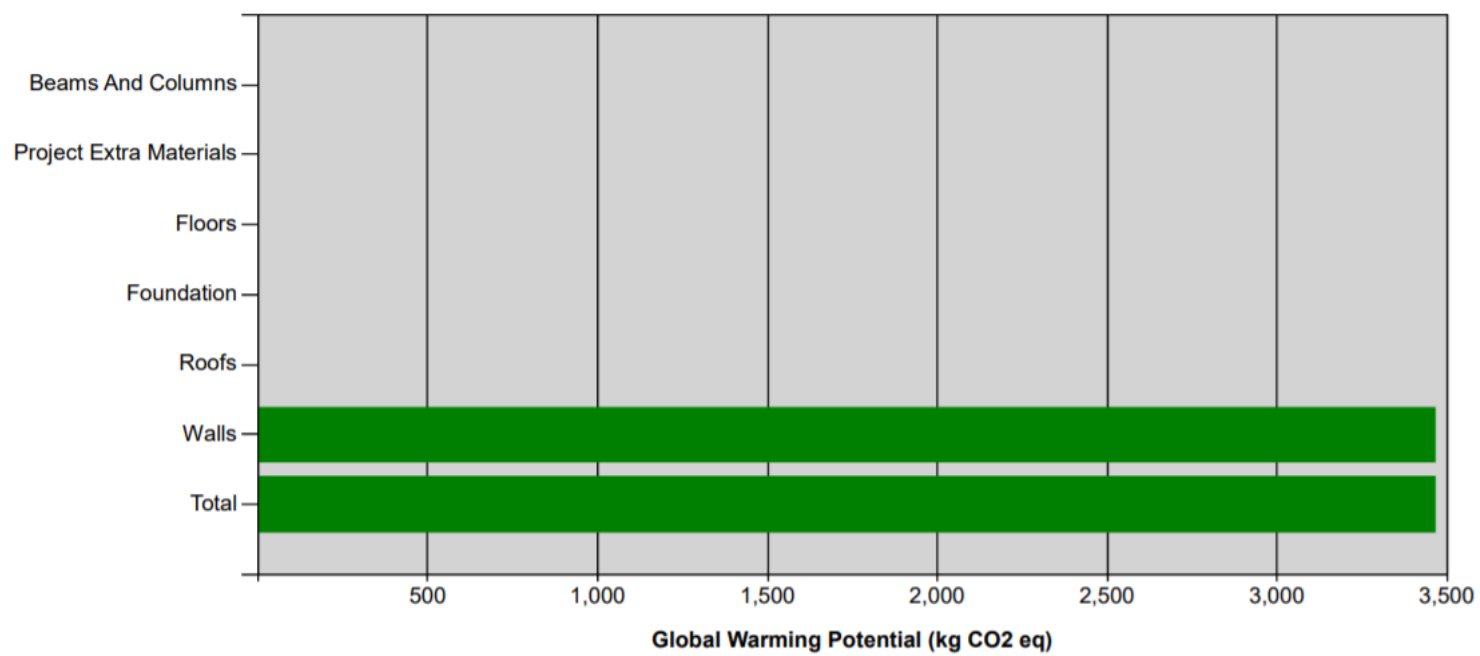

\begin{tabular}{|l|c|r|}
\hline \multicolumn{1}{|c|}{ Assembly Group } & Unit & \multicolumn{1}{c|}{ Total } \\
\hline Beams And Columns & $\mathrm{kg} \mathrm{CO} 2 \mathrm{eq}$ & $0.00 \mathrm{E}+00$ \\
\hline Floors & $\mathrm{kg} \mathrm{CO} 2 \mathrm{eq}$ & $0.00 \mathrm{E}+00$ \\
\hline Foundation & $\mathrm{kg} \mathrm{CO} 2 \mathrm{eq}$ & $0.00 \mathrm{E}+00$ \\
\hline Project Extra Materials & $\mathrm{kg} \mathrm{CO} 2 \mathrm{eq}$ & $0.00 \mathrm{E}+00$ \\
\hline Roofs & $\mathrm{kg} \mathrm{CO} 2 \mathrm{eq}$ & $0.00 \mathrm{E}+00$ \\
\hline Walls & $\mathrm{kg} \mathrm{CO} 2 \mathrm{eq}$ & $3.47 \mathrm{E}+03$ \\
\hline Total & $\mathbf{k g ~ C O 2 ~ e q}$ & $\mathbf{3 . 4 7 E}+\mathbf{0 3}$ \\
\hline
\end{tabular}

Figure 38: Embodied energy of envelope retrofits, 20 years, $A$ to $C$ 
H: Photo Key Plans for Thermography

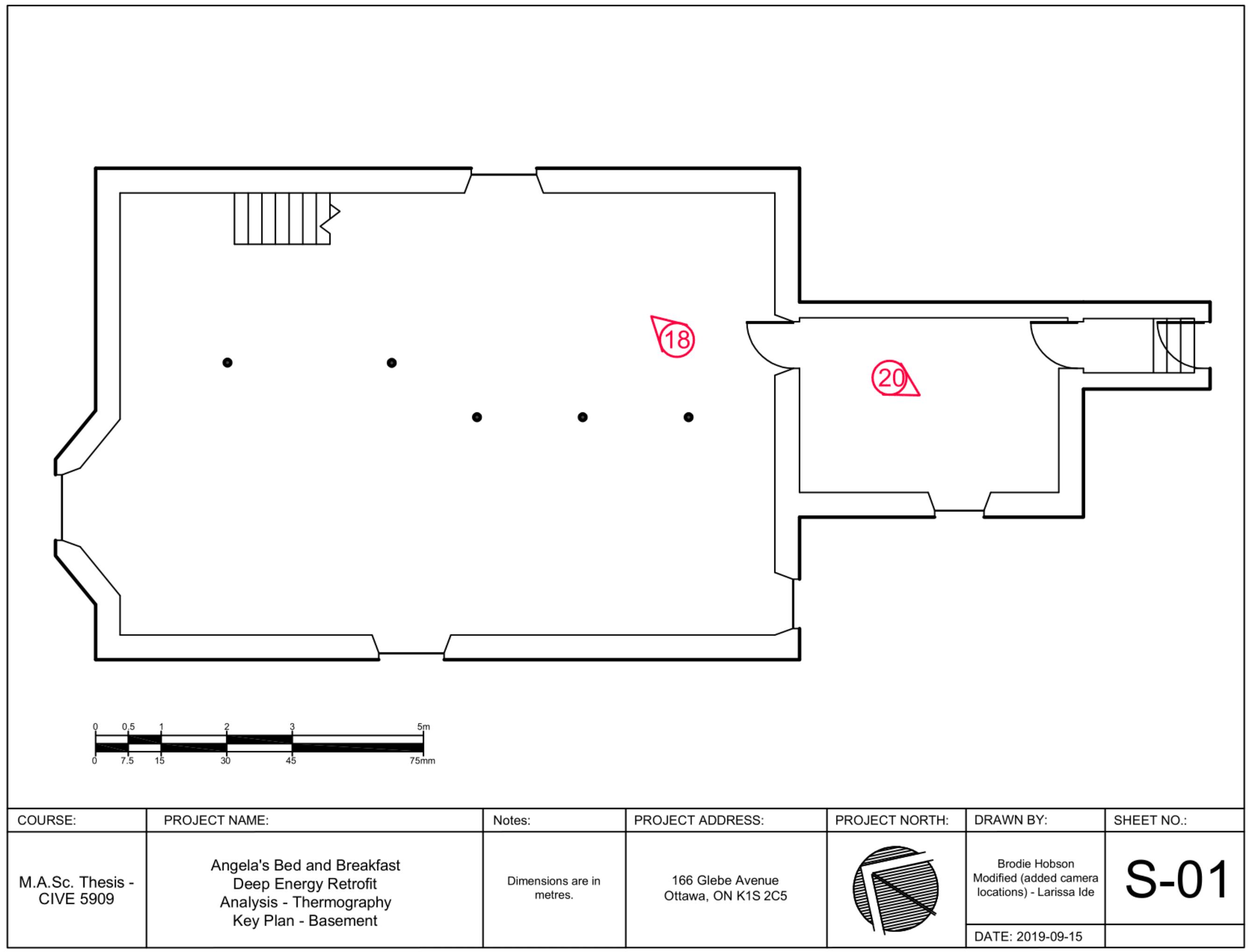




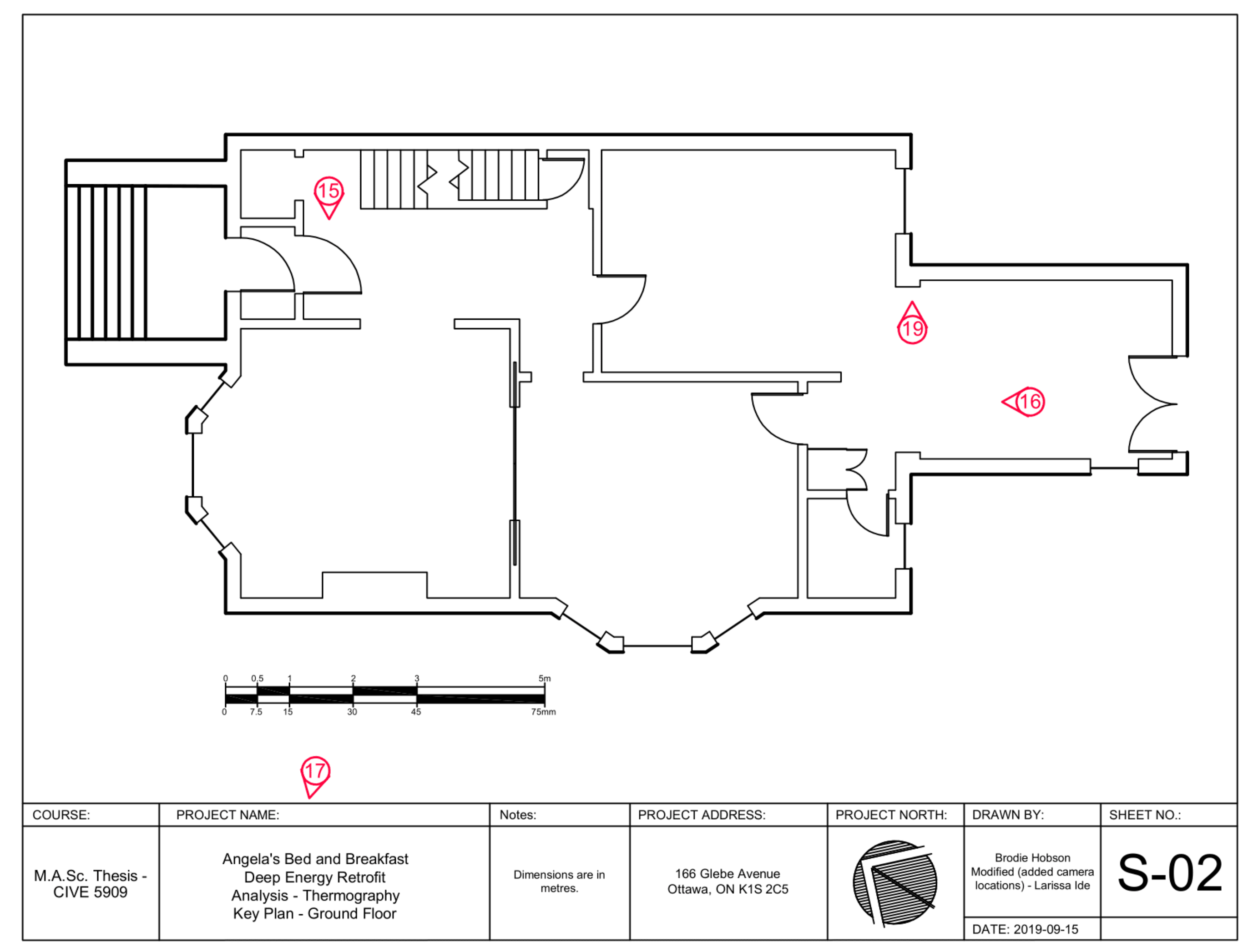




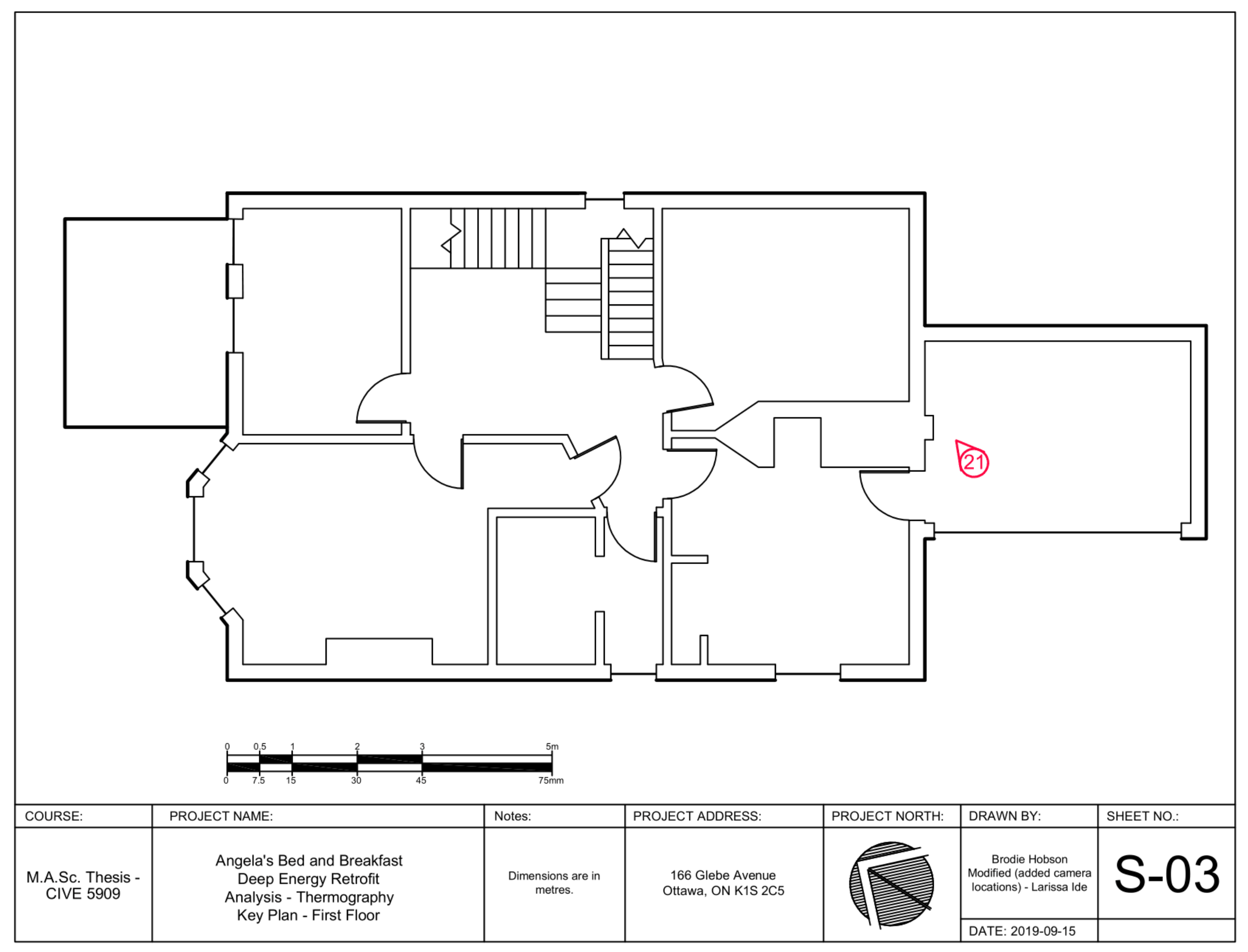




\section{I: Potential Heritage Impact Assessment}

Charts explaining the overall potential heritage impact. See Section 5 of ICOMOS (2011) for the full explanation of this evaluation system.

\begin{tabular}{|c|c|c|c|c|c|}
\hline \multirow[b]{2}{*}{$\begin{array}{l}\text { VALUE OF } \\
\text { HERITAGE } \\
\text { ASSET }\end{array}$} & \multicolumn{5}{|c|}{ SCALE \& SEVERITY OF CHANGE/IMPACT } \\
\hline & $\begin{array}{l}\text { No } \\
\text { Change }\end{array}$ & $\begin{array}{l}\text { Negligible } \\
\text { change }\end{array}$ & $\begin{array}{l}\text { Minor } \\
\text { change }\end{array}$ & $\begin{array}{l}\text { Moderate } \\
\text { change }\end{array}$ & $\begin{array}{l}\text { Major } \\
\text { change }\end{array}$ \\
\hline $\begin{array}{l}\text { For WH } \\
\text { properties }\end{array}$ & \multicolumn{5}{|c|}{$\begin{array}{l}\text { SIGNIFICANCE OF EFFECT OR OVERALL IMPACT } \\
\text { (EITHER ADVERSE OR BENEFICIAL) }\end{array}$} \\
\hline $\begin{array}{l}\text { - attributes } \\
\text { which } \\
\text { convey } \\
\text { OUV }\end{array}$ & Neutral & Slight & $\begin{array}{l}\text { Moderate/ } \\
\text { Large }\end{array}$ & $\begin{array}{l}\text { Large/very } \\
\text { Large }\end{array}$ & Very Large \\
\hline
\end{tabular}

\begin{tabular}{|l|l|l|l|l|l|}
\hline $\begin{array}{l}\text { For other } \\
\text { heritage } \\
\text { assets or } \\
\text { attributes }\end{array}$ & \multicolumn{5}{|c|}{$\begin{array}{l}\text { SIGNIFICANCE OF IMPACT } \\
\text { (EITHER ADVERSE OR BENEFICIAL) }\end{array}$} \\
\hline Very High & Neutral & Slight & $\begin{array}{l}\text { Moderate/ } \\
\text { Large }\end{array}$ & $\begin{array}{l}\text { Large/very } \\
\text { Large }\end{array}$ & Very Large \\
\hline High & Neutral & Slight & $\begin{array}{l}\text { Moderate/ } \\
\text { Slight }\end{array}$ & $\begin{array}{l}\text { Moderate/ } \\
\text { Large }\end{array}$ & $\begin{array}{l}\text { Large/Very } \\
\text { Large }\end{array}$ \\
\hline Medium & Neutral & Neutral/Slight & $\begin{array}{l}\text { Slight } \\
\text { Moderate }\end{array}$ & $\begin{array}{l}\text { Moderate/ } \\
\text { Large }\end{array}$ \\
\hline Low & Neutral & Neutral/Slight & Neutral/Slight & Slight & $\begin{array}{l}\text { Slight/ } \\
\text { Moderate }\end{array}$ \\
\hline Negligible & Neutral & Neutral & Neutral/Slight & Neutral/Slight & Slight \\
\hline
\end{tabular}

